
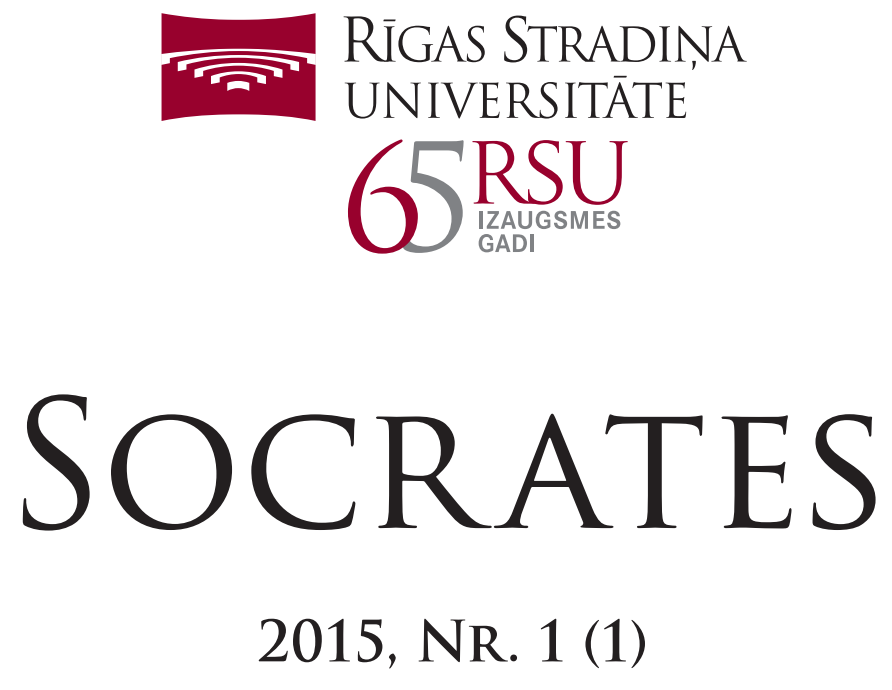

Rīgas Stradiṇa universitātes

Juridiskās fakultātes elektroniskais juridisko zinātnisko rakstu žurnāls

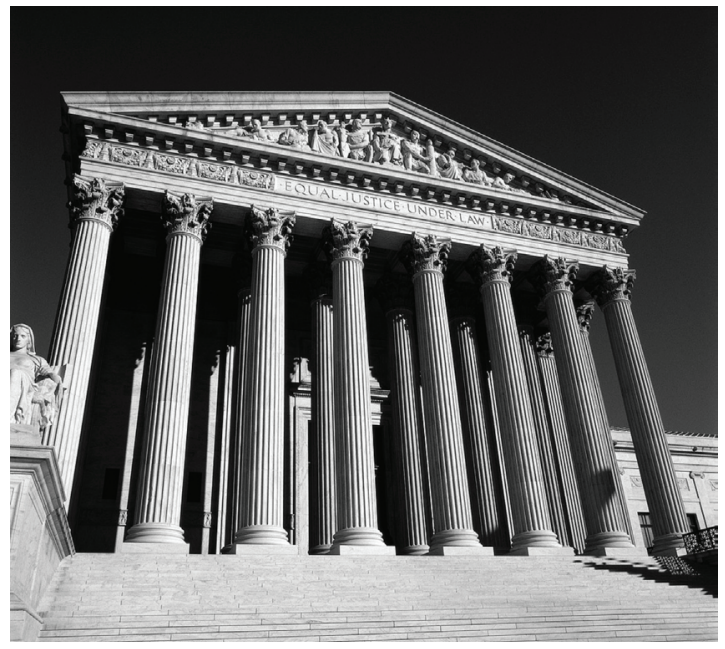

$\mathrm{RI} G A \cdot 2015 \cdot \mathrm{RSU}$ 
Socrates: Rīgas Stradiṇa universitātes Juridiskās fakultātes elektroniskais juridisko zinātnisko rakstu žurnāls. Rīga, RSU, 2015., Nr. 1 (1). 68 lpp.

\section{Redkolēgija}

Jānis Gardovskis (vadītājs) - Dr. habil. med., profesors, Rīgas Stradiṇa universitāte, Latvija Iveta Ozolanta - Dr. habil. med., profesore, Rīgas Stradina universitāte, Latvija

Andrejs Vilks (atb. zin. redaktors) - Dr. iur., profesors, Rigas Stradiña universitāte, Latvija Vladimirs Eminovs, Dr. habil. iur., profesors, Maskavas valsts juridiskā universitāte, Krievija Osvalds Joksts - Dr. habil. iur., profesors, Rīgas Stradiña universitāte, Latvija Tālavs Jundzis, Dr. iur., Dr. habil. sc. pol., Latvijas Zinātṇu akadēmijas viceprezidents Viktoras Justickis - Dr. habil. iur., profesors, Viḷnas Mykolas Romeris universitāte, Lietuva Sandra Kaija - Dr. iur., profesore, Rīgas Stradiṇa universitāte, Latvija Ando Leps - Dr. habil. iur., profesors, Tallinas universitāte Nord, Igaunija Andris Vilks - Dr. phil., asoc. profesors, Rīgas Stradiṇa universitāte, Latvija Jaceks Zielinski - Dr. habil. sc. pol., profesors, Polijas Administrācijas augstākā skola

\section{Redakcijas padome}

(Rīgas Stradiṇa universitāte)

Jānis Baumanis - Dr. iur., vadošais pētnieks

Jānis Grasis - Dr. iur., asoc. profesors

Osvalds Joksts - Dr. habil. iur., profesors

Aldis Lieljuksis - Dr. iur., asoc. profesors

Sandra Kaija - Dr. iur., profesore

Uldis Kinis - Dr. iur, asoc. profesors

Andrejs Vilks - Dr. iur., profesors

Andris Vilks - Dr. phil., asoc. profesors

Tenis Nigulis - Izdevniecības un poligrāfijas dal̦as vadītājs

Visi krājumā ievietotie raksti ir recenzēti.

Recenzenti:

Dr. iur. Jānis Teivāns-Treinovskis

Dr. iur. Ëriks Trel̦s

Citējot atsauce uz izdevumu atsauce ir obligāta.

Autoru viedoklis var nesakrist ar redkolēgijas viedokli.

Par faktu pareizību atbild autori.

Redaktori: Ināra Mikažāne (latviešu val.), Jānis Zeimanis (angḷu val.)

Tehniskā redaktore: Ilze Reitere

Maketētāja: Ilze Stikāne

RSU IPD Nr. 15-030

(C) Rīgas Stradiña universitāte, 2015

Dzirciema iela 16, Rìga, LV-1007 


\section{Saturs}

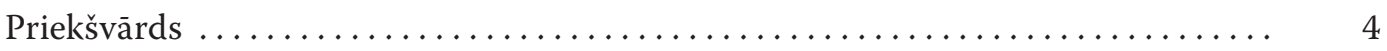

Jānis Baumanis. Ieskats kriminālsodu politikas vīzijā un reālijā ............ 5

Barba Girgensone. Brīvprātīgā dalītā īpašuma rašanās īpašuma sociālās funkcijas un būvniecības kontekstā $\ldots \ldots \ldots \ldots \ldots \ldots \ldots \ldots \ldots, 12$

Inga Kudeikina. Doktrinālā pieeja domājamās dal̦as izpratnei

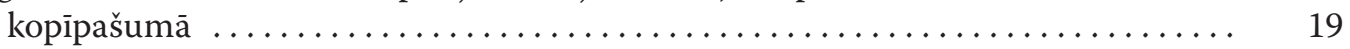

Kristīne Kuznecova. Valsts un pašvaldības kompetence sabiedriskās kārtības nodrošināšanā publiskos pasākumos $\ldots \ldots \ldots \ldots \ldots \ldots \ldots \ldots . \ldots 25$

Aleksandrs Matvejevs. Policijas zinātnes attīstība Eiropā .................. 35

Jānis Meija. Tiesību vienpusēji atkāpties no līguma realizēšanas

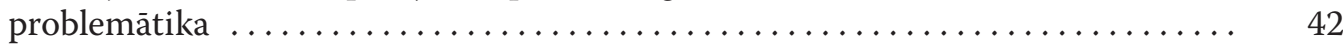

Ivans Jānis Mihailovs. Līgums par bērna izglītošanu izglīīibas iestādē un disciplinnas pārkāpumu novēršana $\ldots \ldots \ldots \ldots \ldots \ldots \ldots \ldots \ldots \ldots \ldots, 47$

Kristine Šelepova. Atjaunojamo energoresursu tiesiskuma nodrošinājums ...... 55

Olga Šǩkerberga. Bērna tiesības zināt savu izcelsmi: tiesību apjoms

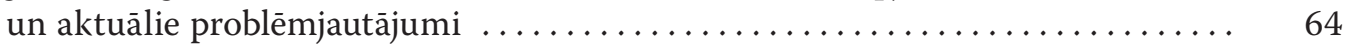

Andrejs Vilks. Psiho- un neirotehnologijas un sabiedriskās drošības

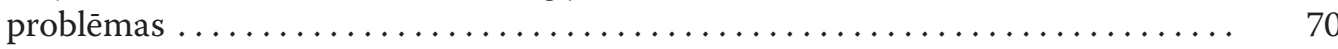

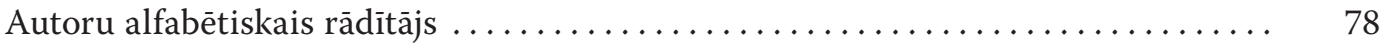




\section{Priekšvārds}

Latvija nevar lepoties ar plašiem un daudzveidīgiem juridisko zinātṇu izdevumiem, kuros būtu publikācijas ar aktuālo Latvijas un starptautisko tiesību problēmu analīzi. Pēdējos gados to skaits pat ir samazinājies. Tajā pašā laikā krasi pieaug juridiska rakstura problēmu daudzums visdažādākajās tiesību jomās, tāpēc aizvien akūtāka kḷust nepieciešamība runāt, diskutēt par tiesību jautājumiem publiskajā vidē, informējot un izglītojot visus interesentus: studentus, akadēmisko personālu un praktiḳus. Vienlaikus jāatzīst, ka juridiska rakstura unikālu un tiesiskajā vidē nepieciešamu pētījumu, to skaitā jauno tiesību zinātnieku, doktorantu, rezultāti publiskajā vidē nav pietiekami plaši pieejami.

Izdot un pavairot drukātus izdevumus modernajā informāciju tehnologiiju laikmetā nav pietiekami konstruktīvi un racionāli. Jurisprudence ir sociālo pakalpojumu joma, kurā digitālās tehnologiijas izmanto visi praktizējošie vai topošie tiesību speciālisti. Tā ir pietiekami izteikta mūsu straujā tehnolog̣iskā laikmeta prasība.

Rīgas Stradiṇa universitāte, ņemot vērā šeit minēto, sāk izdot juridisko elektronisko žurnālu "Socrates". Izdevuma nosaukumā ir viena no Rietumu pasaules filozofijas pamatlicējiem, sengrieḳu domātāja Sokrāta vārds. Viṇa domāšanas un spriešanas veids ir saistīts ar uzskatu pārbaudīšanas metodi, veicot diskusijas - majevtiku. Žurnālā ietvertie raksti, atsevišḳi pētỉjumu rezultāti var tikt uztverti un vērtēti nevienprātīgi, tie, domājams, raisīs diskusijas, viedokḷu apmaiṇu un komentārus. Rakstu autori ir centušies savās publikācijās pievērst uzmanību inovatīviem un atšḳirīgi traktējamiem dažādiem tiesību apakšnozaru aspektiem.

Krājumā ir plānots iekḷaut publikācijas par visām tiesību zinātnes apakšnozarēm, jo pētnieciskie darbi ir vispusīgi un daudzveidīgi. Lasītāji krājumā atradīs plašus materiālus par dažādiem civiltiesiskiem aspektiem, krimināltiesiskām problēmām, policijas tiesībām, bērnu tiesību aizsardzības nodrošinājumu utt. Elektroniskais juridisko zinātṇu žurnāls paredz arī atgriezenisko saiti, veicinot diskusijas elektroniskajā vidē par krājumā ievietotajām publikācijām. Komentārus gaidām tūdal pēc rakstu publicēšanas un ceram, ka "oponentu" attieksme pret publikācijām būs argumentēta un pamatota.

Visi redkolēgijai iesniegtie raksti tiek anonīmi recenzēti un redigéti. Par publikāciju saturu un zinātniskumu atbild to autori.

\section{Žurnāla atbildīgais zinātniskais redaktors profesors ANDrejs ViLKS}




\title{
leskats kriminālsodu politikas vīzijā un reālijā
}

\author{
Jänis Baumanis \\ Rìgas Stradiña universitāte, Juridiskā fakultāte, \\ Tiesību zinātñu katedra, Latvija
}

\section{Kopsavilkums}

Analizējot Krimināllikuma grozijumus un modelējot likuma jaunrades ietekmes scenārijus, autors atklāj savu redzējumu par kriminālsodu politikas attīstību, kurā dominē digitālās tehnolog̣ijas. Autors rakstā aktualizē tiesu un likumdošanas varas savstarpējo mijiedarbību kriminālsodu politikas attīstībā, norādot, ka vērojama tendence likumos iekḷaut tik detalizētas tiesu spriešanas instrukcijas, ka tiesu spriešana faktiski kḷūst par mehānisku darbỉbu.

Atslēgvārdi: Krimināllikums, kriminālsodu politika, soda mērḳis, Tieslietu ministrija.

Raksta mērḳis ir atklāt kriminālsodu politikas attīstību.

Izpētes metodes. Rakstā, analizējot tiesību normu jaunradi, autors modelē kriminālsodu politikas attīstības scenāriju.

Raksta kodols tapa 2013. gada beigās, taču tā saturu aktualizē e-lietas projekts. "Ar e-lietas projektu informatīvā ziṇojuma "Par e-lietas projekta īstenošanu Eiropas Savienības 2014.-2020. gada struktūrfondu plānošanas periodā" saturā tiek apzīmēts projektu kopums kriminālprocesa un administratìvo pārkāpumu procesa elektronizēšanai visos šo procesu posmos galvenajās procesā iesaistītajās iestādēs - tiesu iestādēs, prokuratūrā un izmeklēšanas, kā arī citās iestādēs -, tādējādi palielinot saistìtās informācijas pieeja mību e-vidē, procesu atklātumu, sekmējot lēmumu objektivitāti un veidojot augstāku uzticamību un sabiedrības izpratni." [1,1] E-lietas projektā faktiski ietilpst Kriminālprocesa informācijas sistēmas (KRASS) attīstības nākamais pakāpiens, kurā iecerēts pilnībā digitalizēt krimināllietu.

2013. gada 1. aprīlī spēkā stājās 2012. gada 13. decembra likums "Grozījumi Krimināllikumā", kas samazināja daudzu Krimināllikuma Sevišḳajā dạ̦ā paredzēto sankciju bargumu. Minēto normatīvā akta jaunradi Tieslietu ministrija pamatoja ar 
apstākli, ka praksē tiesas piespriež pārāk bargus sodus. Kā kriminālsodu politikas aktualitāti Tieslietu ministrijas pārstāve 2011. gadā norādīja: "Latvijā brīvības atṇemšanas sodi ir ievērojami bargāki nekā citviet Eiropas Savienībā. Turklāt ne tikai garāki, bet Latvijā likumpārkāpēji tiek notiesāti ar brīvības atṇemšanu arī tādos gadījumos, kad persona nerada reālu sabiedrības drošîbas apdraudējumu. L,oti bargi ir sodi par mantiskajiem noziegumiem - zagšanu, krāpšanu -, tātad par tādiem noziegumiem, kas rada apdraudējumu cilvēka mantai, īpašumam, bet ne dzīvībai un veselībai, ko citur pasaulē uzskata par patiešām nozīmīgiem. .. Salīdzinoši augsts rādītājs Latvijā ir arī tas, cik daudz uz 100 tūkstošiem iedzīvotāju atrodas cietumā iepriekšējā izmeklēšanā vai tajā izcieš sodu. Šajā ziṇā starp 48 Eiropas valstīm esam otrajā vietā. Brīvības atñemšanas sods valstij ir visdārgākais no visiem soda veidiem." $[2,1]$

Tādējādi Tieslietu ministrijas skatījumā sodu bardzība saistīta ar lieliem izdevumiem. Samazinot ieslodzìto personu skaitu, valsts varētu ietaupît budžeta lìdzeklıs.

Tiesību jaunrades ietvaros likumdevēji var mainīt Krimināllikuma Sevišḳās daḷas pantos paredzētās sankcijas - paaugstināt vai samazināt sankcijas augstāko vai zemāko robežu. Rodas jautājums, vai šo robežu bīdīšana nosaka reālos tiesas piespriestos sodus? Pēc būtības reālos piespriestos sodus sankciju grozišsana var iespaidot tikai tad, ja tiesa uzskata, ka par konkrēto noziedzīgo nodarījumu personai jāpiespriež bargāks sods nekā Krimināllikuma Sevišķās daḷas panta sankcijā paredzētā augstākā robeža, vai otrādi, ja tiesa uzskata, ka par konkrēto noziedzīgo nodarỉjumu personai jāpiespriež mazāk bargs sods nekā sankcijā paredzētā zemākā robeža un nepastāv Krimināllikuma 49. pantā paredzētie nosacījumi. Abos gadỉjumos likumdevēji faktiski spriedīs tiesu tiesas vietā. Minētā situācija Latvijas kriminālsodu politiku tuvina sistēmai, kurā tiesa nelemj par soda veidu un apmēru, bet gan tikai konstatē, ka par minēto nodarījumu jānosaka konkrēts sods.

Var sintezēt provizorisko kriminālsodu politikas vispārīgo mērḳi - izveidot datorprogrammu, kas spriedīs tiesu par noziedzìgu nodarījumu izdarǐšanu, n,emot vērā ne tikai noziedzīga nodarījuma raksturu un radīto kaitējumu, vainīgā personību, atbildỉbu mīkstinošos un pastiprinošos apstākḷus, bet arī valsts budžeta līdzekḷu apjomu, kuru var iztērēt soda izpildei. Lìdzīgi kā Iekšlietu ministrija ar KRASS sistēmu, kuru reglamentē 2010. gada 14. septembra Kriminālprocesa informācijas sistēmas noteikumi Nr. 850, iespējams, virzās uz kriminālprocesa gaitas digitalizēšanu, Tieslietu ministrija ar Krimināllikuma normu grozišanu, iespējams, virzās uz to, lai digitalizētu tiesas spriešanu.

Par KRASS Iekšlietu ministrijas mājas lapā norādīts: "Šĩ sistēma l̦aus automatizēt kriminālprocesa lietvedības ciklu, nodrošinot kriminālprocesa gaitā tapušo datu reǵistrēšanu, apstrādi, glabāšanu, pārraidī̌anu un pieejamību, kā arī radot iespēju operatīivi kontrolēt kriminālprocesa lietu virzības gaitu, nodrošināt efektīvu nepieciešamās informācijas (datu) apmaiṇu starp tiesību aizsardzības iestādēm, automatizētu statistikas pārskatu sagatavošanu." $[5,1]$ 
Jāatzīst, ka automatizētās datu apstrādes sistēmas uzturēšana valstij izmaksās lētāk nekā kvalificētu tiesnešu uzturēšana, un KRASS sistēmā apkopotā informācija nākotnē, iespējams, l̦aus automātiski piespriest vainīgajam konkrēto sodu, neiesaistot šajā procesā tiesu. Šāda perspektīva kalpos, lai Latvijā apvienotu likumdošanas un tiesas varu, tādējādi nodrošinot valsts budžeta līdzekḷu uzkrājumu. Jēdzieni "kriminālsodu politika" un "kriminālsodu prakse" kḷūs sinonīmi. Tiesneši vairs nevarēs brīvības atnemšanas sodu piespriest zag̣̣iem un citiem noziedzīgu nodarījumu pret īpašumu izdarìtājiem, tādējādi nepamatoti tērējot valsts budžeta līdzekḷus. Tas būs risinājums tam, kā nabadzīga sabiedrība varēs ietekmēt pastāvošo neaudzinātību un vardarbību, par kuru 2011. gada maija sākumā varēja lasìt plašsaziṇas līdzekḷıs: “"Mums jāṇem vērā Ziemel̦valstu policijas brīdinājums pārskatīt Šengenas līgumu saistībā ar noziedznieku pieplūdumu no Baltijas - mēs esam neaudzināta, vardarbīga un nabadzīga sabiedrība," intervijā Latvijas Radio sacīja aizsardzības ministrs Artis Pabriks." [4, 1] Acīmredzot viens no līdzekḷiem, kā nabadzīgai sabiedrībai ietekmēt vardarbību un neaudzinātību, ir tiesību jaunrade piespiedu lìdzekḷu un represīvo institūtu jomā. Dạa no minētās jaunrades noris kriminālsodu politikas kontekstā. Kriminālsodu politikas koncepcijas kopsavilkumā noteikts: "Kriminālsodu politikas mērḳis ir nodrošināt efektīvu valsts reakciju uz noziedzīgiem nodarījumiem, nodrošināt atbilstību starp valsts vārdā piemērojamo represiju un valsts, un indivīdu interesēm, sekmēt personu tiesisku uzvedību un noziedzīgu nodarījumu novēršanu." [3, 1] Kriminālsodu politikas koncepcijas îstenotāji ir Latvijas Republikas Tieslietu ministrija, kuras pārstāvji norāda, ka: “.. viens no iemesliem, kāpēc tika rakstīta Kriminālsodu politikas koncepcija, bija tieši tas, ka esošā sodu sistēma pēdējo desmit gadu laikā ir padarìta par savstarpēji nesamērīgu, reaǵējot tikai uz konkrētiem notikušiem gadījumiem, nevis sistēmiski." [6, 1]

Lai gan šajā rakstā izklāstītais scenārijs par tiesas spriešanas automatizāciju ir autora iztēles auglis, jāatzīst, ka centieni likumdošanas ceḷā detalizēti reglamentēt soda noteikšanu būtiski sašaurina tiesas lomu tiesas spriešanā.

Redzot šo iespējamo perspektīvu, pavisam citādāk tiek uztverti Tieslietu ministrijas pārstāvja vārdi, ka viens no iemesliem, kāpēc tika rakstìta Kriminālsodu politikas koncepcija, bija tieši tas, ka pašreizējā sodu sistēma pēdējo desmit gadu laikā ir padarīta par savstarpēji nesamērīgu, reaǵējot tikai uz konkrētiem notikušiem gadījumiem, nevis sistēmiski. Kas ir esošā sodu sistēma, kura ir nesamērīga un reageē tikai uz konkrētiem notikušiem gadījumiem? Acīmredzot tā ir esošā tiesu prakse, ka Latvijas tiesneši aț̦aujas brīvības atņemšanas sodu piespriest daudz biežāk nekā citās Eiropas valstīs. Kā nodrošināt sistēmiskumu? Pieņemt normas, kas ietekmētu tiesu praksi un liktu tiesnešiem piespriest tādus soda veidus un mērus, kādus vajag, lai būtu sistēmiskums.

Latvijas Republikas likuma "Par tiesu varu" 1. panta otrajā dạ̦ā noteikts, ka "tiesnesis ir neatkarīgs un pakḷauts tikai likumam". Tādēl, pastāvot sistēmiskuma ieviešanas nepieciešamībai tiesnešu darbā, minēto sistēmiskumu atliek iedzīvināt ar likumu. Vai šis ir vienīgais variants? Autors uzskata, ka pastāv arī alternatīvs problēmas risināšanas variants, proti, piešḳirt Augstākās tiesas judikatūrai likuma spēku. 
Taču Latvijā Kriminālsodu politikas koncepcijā tiesu precedentu sistēma netiek atbalstìta, netieši norādot, ka viss, ko sprieda tiesa, ìsti nav pareizi. Cietumā nav jābūt tik daudz ieslodzitajiem.

Autors, 2009. gadā būdams aktīvs Kriminālsodu politikas īstenošanas darba grupas dalībnieks Tieslietu ministrijā, par pozitīvām atzīst vairākas Kriminālsodu politikas koncepcijā ietvertās atziṇas, kuru rašanās, šḳiet, ir likumsakarīga Latvijai kā romāṇu germāṇu tiesiskas sistēmas valstij. Pozitīvie kriminālsodu politikas aspekti detalizēti un pamatoti ir izklāstīti jau citētajā Tieslietu ministrijas Krimināltiesību departamenta direktores Indras Gratkovskas un juriskonsulta Ulda Zemzara rakstā "Kriminālsodu politikas aktualitātes”. Tomēr autors ar nolūku sabiezināja krāsas, lai atspoguḷotu kriminālsoda politikas un prakses mijiedarbības neizceltās puses un censtos identificēt koncepcijas rašanās cēloṇus. Ja, piemēram, jau koncepcijas iedzivināšanas procesā tiek norādīts, ka Latvijā ieslodzījuma vietās ir pārāk daudz ieslodzìto, vai tas nozīmē, ka tiesnešiem, kas uzlika šo slogu cietumiem, līdz šim bija jāspriež tiesa citādāk? Kas bija līdzšinējās tiesu prakses iemesls, vai Krimināllikuma normu nepilnības? Cik lielā mērā budžeta līdzekḷ taupīšanas politika attiecināma uz kriminālsodu politiku? Vai dažiem ieslodzījuma vietās nokḷuvušajiem, ìpaši jau tiem, kas izcieš sodu par noziedzīgiem nodarījumiem pret īpašumu, būtu jāapzinās, ka tiesu varas, kas piesprieda brīvības atñemšanas sodu, un likumdošanas varas nostāja par to, vai viniem jāatrodas cietumā, ir atškiirīga? Autors atstāj lasītāja ziṇā izvērtēt pašreizējās kriminālsodu prakses un kriminālsodu politikas pozitīvos un negatīvos aspektus.

Turpinājumā kā pozitīvs tiesību jaunrades auglis jāizcel ar koncepciju plānotais, precizētais kriminālsoda mērḳis. Proti, Krimināllikuma 35. panta otrās daḷas jaunajā redakcijā noteikts: "Soda mērḳis ir:

1) aizsargāt sabiedrības drošību;

2) atjaunot taisnīgumu;

3) sodīt vainīgo personu par izdarīto noziedzīgo nodarījumu;

4) resocializēt sodìto personu;

5) panākt, lai notiesātais un citas personas pildītu likumus un atturētos no noziedzīgu nodarījumu izdarǐ̌̌anas."

Šajā normā kā pirmais un tādēl, visticamāk, galvenais soda mērḳa elements tiek izcelts sabiedrības drošỉbas aizsardzība. Šis soda mērḳa elements ir loğisks. Vairāk neskaidrību ir ar otro soda mērḳa elementu, proti, ar taisnīguma atjaunošanu. Tiek pieñemts, ka kaut kad taisnīgums pastāvēja. Acīmredzot tas moments, kad taisnīgums zuda, ir noziedzịga nodarījuma izdarǐšanas brīdis. Taču, n,emot vērā, ka tas ir tikai autora minējums un nekur Krimināllikumā noziedzīga nodarījuma sastāvā taisnīguma izzušana nav obligāta pazīme, iespējams arī cits taisnīguma zušanas moments. Minētā momenta precīza noteikšana ir svarīga, lai izprastu soda mērki. Skaidrs, ka par taisnīguma izzušanas momentu nevar uzskatìt kriminālprocesa uzsākšanas brīdi, jo tad ar galēja nolēmuma spēkā stāšanās brīdi, likumsakarīgi, kriminālprocesa virzība tiek pārtraukta un soda izpildei, kā log̣iskai procesa virzībai, vairs nav jāatjauno taisnīgums. 
Sarežgịitāks ir jautājums par noziedzīga nodarïjuma cēloṇa rašanās brīdi, kas liek zust taisnīgumam. Sodam atjaunot taisnīgumu, kas laupits ar noziedzīga nodarījuma cēloṇa rašanās brīdi, ir problemātiski. Vienīgi šis soda mērḳa elements daḷēji var tikt sasniegts, atzīstot cēloṇus par atbildību mìkstinošiem vai pastiprinošiem apstākḷiem.

Habilitētais filozofijas doktors Ivans Vedins norāda: "Taisnīgums ir sociālās realitātes atbilstība taisnības ideālam. .. Taisnīgums kā sociāla parādība izpaužas objektīvās un subjektīvās realitātes formās. Tāpēc jāatškịir trīs savstarpēji saistītas taisnīguma sociālās dimensijas - īstenība, ideologiija un psihologiija:

1) taisnīguma îstenība ir starppersonu, personības un sabiedrības, kā arī dažāda mēroga sociālo sistēmu attiecības;

2) taisnīguma ideologiija ir sociālā taisnīguma ideālu pamatojums politiskajā, tiesiskajā, ètiskajā un religisiskajā mācībā;

3) taisnīguma psihologijai ir priekšstati par taisnīguma ideāliem individuālās un sabiedriskās izziņas sfērā.

Taisnīguma īstenošanu ietekmē gan ideologija, gan dažādu sociālo slāṇu psihologiija. Piemēram, saskañā ar šariata likumiem Irānā kabatzādzību tiek nocirsti pirksti, par atkārtotu zādzību - roka. Tajā pašā laikā gan taisnīguma ideologijia, gan psihologija ar laiku mainās atbilstoši reālajām cilvēkattiecību izmaiṇām." [7, 674] N̦emot vērā minēto, jājautā, kāda Latvijā ir taisnīguma îstenība, ideolog̣ija un psiholog̣ija? Publiski tiek uzsvērts, ka Latvijā ir analogiiskās taisnīguma sociālās dimensijas kā pārējās Eiropas Savienības valstīs. Taču, n,emot vērā rakstā norādīto Ziemeḷvalstu policijas brīdinājumu, Latvijā varbūt ir sava individuālā taisnīguma īstenība, ideolog̣ija un psiholog̣ija? Ja tā patiesi arī ir, tad kriminālsodu politikas ietvaros, cenšoties ietekmēt kriminālsodu praksi, būtu jāṇem vērā Latvijas taisnīguma dimensija, atbilstīgi kurai zag̣̣i un citi vainīgie noziedzīgu nodarījumu pret īpašumu izdarīšanā parasti sēž cietumā.

Ceturtais soda mērḳa elements, kas Krimināllikumā atzīstams par novitāti, ir sodìto personu resocializācija, citiem vārdiem, vainīgo atgriešana sabiedrībā. Minētais soda mērḳa elements faktiski uzliek tiesai pienākumu, spriežot tiesu un izvēloties soda veidu un mēru, izvērtēt soda spēju resocializēt tiesājamo.

Ir likumsakarīgi, ka starp kriminālsoda mērḳa elementiem resocializācija atrodas pēc vainīgās personas sodīšanas par izdarīto noziedzīgo nodarījumu. Soda izpilde ir tā, kas bieži vien izstumj personu no sabiedrības, nevis noziedzịga nodarījuma izdarīšanas fakts liek personai attālināties no sabiedrības. Sarežğìtāk sasniegt šo soda mērḳa elementu, ja persona pirms noziedzịga nodarījuma veikšanas jau bija izstumta no sabiedrības vai savas deviantās uzvedības dēl nevēlējās iekḷauties sabiedrībā.

Pēdējais kriminālsoda mērḳa elementu sarakstā, kas iekḷauts Krimināllikuma 35. panta otrās daḷas redakcijā, ir panākt, lai notiesātais un citas personas pildītu likumus un atturētos no noziedzīgu nodarījumu izdarīšanas. Vispārīgā un vispārējā prevencija ietilpst arī vecajā Krimināllikuma 35. panta redakcijā. Jāatzìst, lai sasniegtu to, ka personas pilda likumus un atturas no noziedzīgu nodarījumu izdarīšanas, nepieciešams, lai cilvēki būtu informēti par piemērotajiem sodiem. Autoram nav zināms, 
kā prokuratūra informē sabiedrību par sodiem, kurus piemēroja ar prokurora priekšrakstiem. Jāatzīst, ka arī tiesas spriedumu pieejamība Latvijā ir tikai daḷēji îstenota. Šis jautājums varētu tikt atrisināts kriminālsodu politikas ietvaros, ieviešot tiesiski reglamentētus sabiedrības informēšanas līdzekḷus.

Jāuzsver, ka soda mērḳi nekādā gadījumā nedrīkst jaukt ar kriminālsoda politikas mērḳi. Kriminālsodu politikas mērḳis ir kḷut par noziedzības determinantu, kas samazina noziedzības kvantitatīvos rādītājus un uzlabo noziedzības kvalitatīvos rādìtājus. Taču mūsdienu Latvijas kriminālsodu politika ir kompromisa meklējums starp noziedzības novēršanai un apkarošanai novirzìtajiem valsts budžeta līdzekḷiem un vēlmi tuvināties Eiropas tiesībsargājošo institūciju praksei un rezultātiem, turklāt kritērijs, kas nosaka kriminālsodu politikas vektoru, ir ieslodzìto personu skaits. Vai šãda pieeja l̦aus kriminālsodu politikai kḷūt par noziedzības determinantu? Lai atbildētu uz šo jautājumu, jāatzīst, ka Kriminālsodu politikas koncepciju precīzāk varētu nosaukt par kriminālsodu piemērošanas politikas koncepciju, jo tie, kuri cer šajā koncepcijā atrast kriminālsodu izpildes konceptuālos politiskos aspektus, vilsies. Kriminālsodu politikas koncepcijas ietvaros uz Saeimu tika virzīti Krimināllikuma normu grozijumi, nevis Sodu izpildes kodeksa grozījumi. Zinot minēto, kḷūst redzams, ka šobrīd kriminālsodu politikā ir akcentēta uzmanība uz sodu piemērotājiem, nevis uz sodu izpildìtājiem.

Sodu piemērošanas brīdī tiesa vai prokurors var izvērtēt konkrētam vainīgajam piemērojamā soda veida un mēra potenciālo ietekmi. Taču soda mērḳa sasniegšana ir sodu izpildošo institūciju uzdevums.

Noslēgumā jāpievērš uzmanība tam, ko mūsdienu krimināltiesiskās normas tieši un nepārprotami norāda, t. i., ka kriminālprocess dalẹeji jau panāk soda mērḳi, jo, piemēram, nepamatota novilcināšana un tiesību uz kriminālprocesa pabeigšanu saprātīgā termiṇā neievērošana šobrīd atzìta par soda veida un mēra izvēles kritēriju. Turklāt saskaṇā ar Kriminālprocesa likuma 14. panta piekto daḷu saprātīga termiṇa neievērošana var būt pamats kriminālprocesa izbeigšanai. Tādējādi varētu saprast, ka kriminālprocesa gaita ietekmē taisnīguma atjaunošanu, sabiedrības drošības aizsardzību, resocializāciju un citus soda mērḳa elementus, jo sodam vairs nav jābūt tik bargam vai vispār nav jābūt. Ne velti kriminālsodu politikas koncepcijā sodu sistēmas pilnveides nepieciešamības izcelšanai tika piesaukts ne tikai brīvības atñemšanas sodu izcietušo personu skaits, bet arī apcietinājumā esošo personu skaits. Teorijā un tiesību normās gan sodus un drošības līdzekḷus norobežo, norādot, ka tiem ir citi piemērošanas mērḳi.

Redzot visu šo ainu, autors nāk pie atzinas, ka gan Tieslietu ministrija, īstenojot dekriminalizāciju, gan Iekšlietu ministrija, kura centās ietaupìt budžeta līdzekḷus, samazinot policijas resursus, paralēli līdzsvaro kriminālprocesa un sodu piemērošanas praksi. Ar ironiju var secināt: ja minētie procesi netiks līdzsvaroti, līdz tiesai var nonākt daudz vairāk kriminālprocesu, kuru dēl palielināsies ieslodzìto skaits un būs jātērē valsts budžeta līdzekḷi viṇu uzturēšanai. 


\section{Review of Vision and Realia of Criminal Penalty Policy}

\section{Abstract}

The study includes analysis of the aim of the Criminal Law. Thus, the article reflects the vision and realia of criminal sentences in relation to amendments to the Criminal Law, which came into effect on 1 April 2013. The author concludes that the amendment of the sanctions provided in the Criminal Law, based on the fact that there are too many people in prisons in Latvia, is incorrect.

Keywords: Criminal Law, Criminal Penalty Policy, Objective of Punishment, Ministry of Justice.

\section{Literatūra}

1. Ar e-tiesvedību cer veicināt tiesiskās informācijas pieejamību un samazināt tiesvedības terminu, [skatīts 30.01.2015.]. Iegūts no: http://www.juristavards.lv/zinas/265028-ar-e-tiesvedibu-cer-veicinat-tiesiskas-informacijas-pieejamibu-un-samazinat-tiesvedibas-terminu/

2. Gratkovska, I., Zemzars, U. Kriminālsodu politikas aktualitātes, [skatīts 30.01.2015.] Iegūts no: http://www.juristavards.lv/?menu=DOC\&id=229439

3. Kriminālsodu politikas koncepcijas kopsavilkums. 2009. gada 9. janvāra Ministru kabineta rīkojums Nr. 6, [skatīts 30.01.2015.]. Iegūts no: http://www.likumi.lv/doc.php?id=186355

4. Pabriks: Mès esam neaudzināta, vardarbìga un nabadzìga sabiedrība, [skatīts 30.01.2015.]. Iegūts no: http://www.kasjauns.lv/lv/zinas/46722/pabriks-mes-esam-neaudzinata-vardarbigaun-nabadziga-sabiedriba

5. Paredz vienotas kriminālprocesa informācijas sistēmas izveidi, [skatīts 30.01.2015.]. Iegūts no: http://www.iem.gov.lv/lat/aktualitates/informacija_medijiem/?doc=19050

6. TM negrasās piekāpties IeM un pastiprināt atbildību par uzbrukumu likumsargiem, [sk. 30.01.2015.] Iegūts no: http://www.diena.lv/lat/politics/hot/tm-negrasas-piekapties-iem-un-pastiprinatatbildibu-par-uzbrukumu-likumsargiem

7. Vedins, I. Zinātne un patiesība. Rīga: Avots, 2008. 702 lpp. 


\title{
Brīvprātīgā dalītā īpašuma rašanās īpašuma sociālās funkcijas un būvniecības kontekstā
}

\author{
Barba Girgensone \\ Latvijas Juristu apvienība, Latvija
}

\section{Kopsavilkums}

Brīvprātīgais dalītais īpašums ir veidojies, kopš atjaunots Civillikums, šajā laikā ir attīstījusies tiesu prakse par zemes gabala nodošanu lietošanā ar tiesībām būvēt ēku kā patstāvīgu īpašuma objektu, bet nav vienota normatīvā regulējuma par prasībām, kas jāizvirza būvniecības ierosinātājam kā būves faktiskajam valdītājam būvniecības procesā un īpašuma sociālās funkcijas kontekstā.

Atslēgvārdi: brīvprātīgais dalītais īpašums, īpašuma sociālā funkcija, zemes nomas līgums, faktiskais valdītājs.

Pēdējos gados Latvijā laiku pa laikam uzvirmo diskusija par tā saucamajām “apbūves tiesībām”, kuru ieviešana varētu izbeigt dalītā īpašuma rašanos un pastāvēšanu, paredzot, ka Civillikumam jāreglamentē "apbūves tiesību" jautājumus, piemēram, kā tas ir Igaunijā. Šis raksts atspoguḷo vienu no aspektiem, kas būtu jāṇem vērā šāās diskusijās, proti, brīvprātīgo dalīto īpašumu, kas rodas, būvējot ēkas uz svešas zemes. Un tieši - jāakcentē šā procesa būtība jaunā būvniecības tiesiskā regulējuma un īpašuma sociālās funkcijas kontekstā.

Pirmkārt, Latvijas Republikas Augstākās tiesas Senāta Civillietu departamenta 2010. gada 22. decembra spriedumā lietā Nr. SKC-250/2010 [1] norādìts, ka likuma "Par atjaunotā Latvijas Republikas 1937. gada Civillikuma ievada, mantojuma tiesību un lietu tiesību daḷas spēkā stāšanās laiku un kārtību“ 14. panta pirmās daḷas 5. punkta [5] mērḳis ir noregulēt izṇēmuma situāciju, kurā ēkas (būves) un zemi iespējams reǵistrēt kā atsevišḳus īpašuma objektus un šajā normā likumdevējs par būtisku atzinis apstākli, ka zemes gabala îpašnieks labprātīgi nodevis citai personai tiesības izmantot šo zemes gabalu būvniecībai, proti, zemes īpašnieks nodevis sava zemes gabala lietošanas tiesības citai personai un rakstveidā devis atḷauju celt uz sev piederošās zemes ēkas 
(būves) kā patstāvīgus īpašuma objektus, turklāt jautājums par samaksas pienākumu, kārtību un apmēru, ko zemes īpašnieks varētu pieprasìt no ēkas (būves) ìpašnieka, šajā aspektā nav izškirošs, tāpēc ka likumdevēja mērḳi sasniedz kā nomas, tā patapinājuma lïgums, jo abos gadijumos zemes īpašnieks ir devis savu piekrišanu tam, ka viṇa zeme tiek lietota vispirms èkas būvniecībai un pēc tam uzbūvētās ēkas ekspluatācijai.

Tādējādi likums piel̦auj, ka zemesgrāmatā tiek reǵistrēti divi patstāvīgi îpašuma tiesību objekti - zeme un ēka atsevišksi, vienlaikus katram no tiem nosakot aprobežojumu par labu otram īpašumam, īpaši uzsverot zemes nomas attiecỉbu nodibināšanu.

Minēto patstāvīgo īpašuma tiesību objektu regiistrācija zemesgrāmatā gan nenotiek vienlaikus, jo ēkas (būves) celtniecība ir ilgs process, kas sākas ar tā ierosināšanu un beidzas ar ēkas (būves) nodošanu ekspluatācijā, kad šì celtne kā patstāvīgs īpašuma objekts var tikt regiistrēta zemesgrāmatā. Lìdz tam ēka (būve) tiek uzskatīta par jaunbūvi, un tās īpašniekam saskaṇā ar Civillikuma 968. pantu vajadzētu būt zemes īpašniekam, bet tiesiskajam valdītājam - ēkas (būves) pasūtītājam (termins lietots Būvniecības likuma 14. pantā [3]).

Vispārīgo būvnoteikumu 3. punktā [12] noteikts, ka "būvniecību var ierosināt zemes vai būves īpašnieks, vai, ja tāda nav, - tiesiskais valdītājs vai lietotājs, kuram ar līgumu noteiktas tiesības būvēt", kas šajos noteikumos tiek dēvēts par "būvniecības ierosinātāju". Tikpat labi būvniecības ierosinātājs var būt arī būvētājs, kas saskaṇā ar Vispārīgo būvnoteikumu 2. punktu [12] "ir fiziska persona - zemes vai būves īpašnieks -, jeb Būvniecības likuma izpratnē, kas speciālajos būvnoteikumos noteiktajos gadījumos savām vajadzībām pats organizē būvdarbus, piedalās tajos un uzṇemas vadìtāja pienākumus". Savukārt Būvniecības likuma 19. panta 1. punktā [3] ir uzskaitīti būvniecības procesa dalïbnieki - zemes ippašnieks, būves īpašnieks, būvprojekta izstrādātājs, būvdarbu veicējs, būvuzraugs un būveksperts, norādot, ka par būves īpašnieku uzskatāms arī būves tiesiskais valdītājs. No iepriekš minētā jāsecina, ka nav viegli orientēties būvniecības tiesiskā regulējuma pamatjēdzienos, kas ietverti gan Būvniecības likumā, gan Vispārīgajos būvnoteikumos, tomēr par brīvprātīgo dalīto īpašumu ir būtiski izprast, kad ēkas īpašnieks, kas nav zemes īpašnieks, iegūst ēkas īpašuma tiesības pilnā apjomā, kaut arī Būvniecības likumā viṇš tiek saukts par būves īpašnieku kopš būvaț̦aujas saṇemšanas brīža.

Ja būvniecības ierosinātājs un būvētājs nav zemes īpašnieks, un zemes gabala īpašnieks ir labprātīgi piekritis ēkas (būves) celtniecībai uz viṇa zemes, noslēdzot tiesisku darījumu, saskaṇā ar kuru attiecīgā zemes gabala lietošanas tiesības par noteiktu atlīdzību vai bez tās uz noteiktu laiku, kas nav mazāks par 10 gadiem, ir nodotas būvniecības ierosinātājam, tad brīvprātīgi tiek radìts dalītais īpašums.

N̦emot vērā iepriekš minēto, var teikt, ka brīvprātīgais dalïtais īpašums rodas, ja starp noteikta zemes gabala ìpašnieku un tā lietotāju tiek noslēgts atlīdzības vai bezatlīdzības zemes gabala lietošanas līgums uz laiku, ne mazāku par 10 gadiem, piešḳirot tiesības zemes gabala lietotājam būvēt èku (būvi), reǵistrēt uzcelto ēku (būvi) kā patstāvīgu īpašuma objektu un ekspluatēt to. 
Otrkārt, uzskatot, ka vienīgais tiesiskais pamats brīvprātīgā dalītā īpašuma izveidei ir tiesiski noslēgts zemes lietošanas līgums, būtu jāvadās arī no tā, ka tiesisks pamats būvniecībai konkrētajā zemes gabalā ir īpašnieka īpašumtiesības uz zemes gabalu, kas regiistrētas zemesgrāmatā, jo nekustama lieta saskaṇā ar profesora J. Rozenfelda doto definīciju ir "zemes gabali, kā arī būves un dzīvokḷa ỉpašumi, kas saskaṇā ar likumu ir ierakstāmi zemesgrāmatā kā patstāvīgi nekustami īpašumi." [8]

Tātad arī zemes gabala nomnieka nomas (zemes lietošanas tiesībām ar tiesībām būvēt èku kā patstāvīgu īpašuma objektu) tiesībām vajadzētu būt reǵistrētām zemesgrāmatā pirms būvatḷaujas, kas ir administratīvais akts ar nosacījumiem būvniecības ieceres realizācijai dabā (Būvniecības likuma 2. pants [3]). Savukārt patapinājuma tiesības zemesgrāmatā reǵistrēt nevar (sk. Augstākās tiesas Civillietu tiesu palātas 2008. gada 10. novembra lēmumu lietā Nr. PAC-1986 un 2009. gada 14. decembra lēmumu lietā Nr. PAC-2356.), un tāpēc no būvniecības tiesiskā regulējuma viedokḷa Būvniecības likumā būtu jānoteic, ka tikai uz zemesgrāmatā registrēta nomas līguma pamata cita persona var veikt būvniecību attiecīgajā zemes gabalā.

Ne tikai atsaucoties uz iepriekš minēto, bet ņemot vērā arī to, ka "īpašuma sociālā funkcija uzliek par pienākumu katram īpašniekam rēḳināties ar citu interesēm, kas savukārt noteic, ka valstij ar tiesiskā regulējuma palīdzību ir tiesības ierobežot īpašuma izmantošanu un atsavināšanu saskaṇā ar sabiedrības interesēm, un, lai īpašuma ierobežošana būtu tiesiska, ierobežojumiem jābūt noteiktiem ar likumu, tiem jābūt ar leǵitīmu mērḳi un samērīgiem," [13] jānorāda, ka šāda prasība, kas tiktu iekḷauta Būvniecības likumā, sekmētu izpratni par valsts un pašvaldību rūpēm par to, lai sabiedrības intereses neciestu no nekustamā īpašuma īpašnieku voluntāras darbības.

Treškārt, līdz šim ir nepamatoti kritizēts viens no mehānismiem, kas aizstāv sabiedrības intereses un akcentē īpašuma sociālo funkciju, un konkrēti - valsts vai pašvaldības pirmpirkuma tiesības uz īpašas kategorijas nekustamajiem ipašumiem. Pirmpirkuma tiesības tiek realizētas ar tādu normatīvo regulējumu, kas satur gan mērḳi, gan realizācijas mehānismu un šīs tiesības tiek îstenotas gadījumos, ja īpašnieks ir nolēmis savu īpašumu pārdot.

Arī zemesgrāmatā pieejamā informācija par iespējamību izveidot vai jau izveidotu dalīto īpašumu nodrošina īpašuma sociālo funkciju, jo sekmē teritoriālā plānojuma respektēšanu, lokālā plānojuma izstrādi, apgrūtināto teritoriju reǵistra un kadastra regiistra sakārtošanu, zemes īpašnieka un būvniecības ierosinātāja atbildības nošḳiršanu būvniecības laikā.

Tā kā būvniecība ir visu veidu projektēšana un būvdarbi kopā, tad vienu èkas (būves) objektam tā var ilgt vairākus gadus un maksimāli turpināties 12 gadus.

Ēkas, kas uzbūvēta uz citai personai piederošas zemes, ippašumtiesības būvniecības ierosinātājs iegūst tikai pēc šīs ēkas nodošanas ekspluatācijā un īpašumtiesību nostiprināšanas zemesgrāmatā. Tāpēc līdz šim brīdim būvniecības ierosinātājs ir ēkas (būves) faktiskais valdītājs, jo lietas (arī nekustamas) valdījums ir īpašuma tiesībai atbilstoša faktiska vara pār lietu; tas pastāv, kad kermeniska lieta faktiski atrodas kādas personas 
pilnīgā varā un kad turklāt šĩ persona izrāda gribu rīkoties ar lietu līdzīgi ỉpašniekam, [4] un tāpēc nav svarīgi, vai būve ir vai nav nodota ekspluatācijā, bet ir svarīgi, vai Būvniecības likumā norādīts, ka atbildīgs par būvdarbu uzsākšanu vai veikšanu bez būvaț̣aujas, normatīvajiem aktiem atbilstoša būvprojekta izstrādātāja, būvdarbu veicēja un būvuzrauga izvēli [3] ir èkas (būves) faktiskais valdìtājs - persona, kuras faktiskā varā èka (būve) atrodas un kas Būvniecības likuma 19. panta 1. punktā iekḷauts Būvniecības procesa dalībnieku vidū un nosaukts par ēkas (būves) īpašnieku.

Var teikt, ka faktiskā vara ir nosacìts termins, jo tā nenodrošina absolūtu varu pār lietu tīri fiziskā nozīmē, bet norāda to, ka personai, kurai šì vara pieder, ir radīti priekšnoteikumi tās izlietošanai. [7, 41] Arī lietas faktiskajam valdītājam, tāpat kā īpašniekam, nepieder absolūtas tiesības uz lietu, ko neierobežo nekādi citi apsvērumi vai ierobežojumi, izṇemot gribu, jo īpašnieka un arī valdìtāja gribas izpausme attiecībā uz rīcības brīvību ierobežojama ar ìpašuma, tostarp nekustamā ìpašuma, sociālo funkciju, kas uzliek katram īpašniekam pienākumu rēḳināties ar citu interesēm, [14, 191] arī būvniecības procesā, respektējot kaimiṇu tiesības, ievērojot Būvniecības likumu un ar to saistītos normatīvos aktus, kā arī vispārīgos tiesību principus.

Ceturtkārt, jānorāda, ka Latvijas Republikas Augstākās tiesas Senāta Civillietu departamenta 2008. gada 29. oktobra spriedumā lietā Nr. SKC - 354/2008 teikts, ka ēkas (būves), kas uzceltas uz citai personai piederoša zemes gabala, par patstāvīgu ìpašuma objektu uzskatāmas tikai laikā, kamēr ir spēkā zemes nomas līgums. [2] Izbeidzoties nomas līgumam, izbeidzas arī èkas ìpašnieka ỉpašuma tiesības uz uzcelto ēku. Tas ir būtisks apstāklis jautājuma izlemšanā par kopīpašuma tiesību atzīšanu ēkas un zemes īpašniekiem atbilstīgi Civillikuma 1067. panta pirmās daḷas noteikumiem. [2] Minētajā spriedumā iekḷautajam tiesas secinājumam, ka likums nenosaka, ka nomnieks, kurš ir uzcēlis èku uz nomātas zemes, iegūst kopīpašuma tiesību ar īpašnieku uz zemesgabalu un pārējām ēkām, būtu jāvērš to būvēt gribētāju, kas nav zemes īpašnieki, uzmanība uz nākotnē iespējamām problēmām, kas var būt saistītas ar īpašumtiesību apjomu.

Gadījumos, kad ēka uzcelta uz nomātas zemes, ir diezgan ierobežotas iespējas piemērot Civillikuma normas par izdevumu atlīdzināšanu. Izdevumi saskaṇā ar Civillikumu tiek iedalìti nepieciešamajos, derīgajos un greznuma izdevumos. Saskaṇā ar Civillikuma 969. pantu, ja kāds apzināti uzceḷ patstāvīgu ēku uz svešas zemes, viņ̌̌ var prasìt par to atlīdzību tikai tādā mērā, kādā šì ēka ietilpst nepieciešamos izdevumos, bet, ja ēka pieder tikai pie derīgajiem vai greznuma izdevumiem, tad tās cēlējam ir tikai tiesības to nojaukt un aizvest. Tātad, ja nomas līgumā nebūs nekas šādam gadỉjumam paredzēts, èkas īpašniekam pēc nomas līguma izbeigšanās būs tiesības vienīgi šis èkas nojaukt un aizvest. [11]

Tas vien, ka zemesgrāmatā it kā pastāv divi patstāvīgi īpašuma tiesību objekti zeme un èka - atsevišḳi, vienlaikus katram no tiem nosakot aprobežojumu par labu otram īpašumam, nav neapstrīdami uztverams fakts, turklāt praktiski tikai vienas no īpašuma tiesībām ir reāli izmantojamas, turpretī otras šajā gadījumā cieš no aprobežojuma un reāli nav izlietojamas, jo zemes ipašnieks nevar savu zemi nedz neierobežoti 
valdìt, nedz lietot, nedz arī rīkoties ar to, un vinam ir jānodrošina netraucēta zemes lietošana un viṇam nav tiesību uzteikt nomas līgumu. Tādējādi reāli èkas un zemes īpašuma tiesību atsevišḳ pastāvēšana noved pie tā, ka zemes ipašnieka tiesības ir būtiski aprobežotas par labu ēkas īpašniekam.

Jāsecina, ka Būvniecības likumā un ar to saistìtajos normatīvajos aktos ietvertais regulējums par ēku (būvju) būvniecību uz lietošanā nodota zemes gabala, pat neprasot nomas tiesību reǵistrēšanu zemesgrāmatā būvațaujas izsniegšanas brīdī, sarežğì vai pat padara neiespējamu nākotnē mazināt vai izbeigt dalītā īpašuma radǐšanu. Kaut dalìtais īpašums kopumā nav problēma, un pat Civillikums paredz èkas un zemes kā pilnīgi patstāvīgu īpašuma objektu eksistenci, ja sistēmiski tiek tulkots Civillikuma 968. pants, $[6,18]$ problēma ir atbilstīga tiesiskā regulējuma trūkums, jo nav normatīvi nostiprināts, kas notiek ar būvēm pēc zemes nomas līguma beigām, kas notiek ar trešo personu labā uz būvēm registrētiem apgrūtinājumiem (hipotēkām).

Šobrīd jautājuma risināšanai tiek piedāvāti grozījumi Civillikumā, paredzot apbūves tiesību regulējumu. Profesors J. Rozenfelds savukārt ir veicis pētījumu Tieslietu ministrijai un uzskata: "Dalīta īpašuma situācijai raksturīgu institūtu (mantojamā noma, apbūves tiesības) vai īpašumtiesīga lietojuma (VLK 942.-952. p.) ieviešana ir viens no iespējamiem veidiem, kā nodrošināt priekšnoteikumus dalìta īpašuma atrisināšanai ar tradicionāliem, plašākai internacionālai juristu sabiedrībai pazīstamiem paṇēmieniem." [9]

Tieslietu ministrijas uzdevumā veiktajos pētỉjumos autori ir norādỉjuši, ka zemes un ēku dalītas reǵistrācijas problēmu risināšanai iespējami divi virzieni: orientēšanās uz dalìta īpašuma izbeigšanu vai arī tā padarī̌̌nu par patstāvīgu, piel̦aujamu izṇēmumu. [10] Var piekrist uzskatam, ka dalìtais īpašums Latvijā - gan piespiedu, gan brīvprātīga dalītā īpašuma formās - ir tik dziḷi iesakṇojies un pastāv tik lielā skaitā, ka doma par tā pilnīgu izbeigšanu ir utopija. [11]

Pašlaik iedzīvinot jauno Būvniecības likumu un izstrādājot likumprojektu par grozìjumiem Civillikumā, kas būtībā skar jautājumu par brīvprātīga dalītā ìpašuma turpmāko tiesisko regulējumu, ir vērojams, ka nenotiek institūciju sadarbība, jo vienota regulejjuma "ekonomiskai būtībai būtu jāḷauj zemes ìpašniekiem nodot zemi citai personai apbūvei uz konkrētu laiku un šajā laikā vienīgā zemes ìpašnieka interese būtu samaksas saṇemšana, kā arī zemes gabala saṇemšana atpakal pēc nolīgtā termiṇa beigām". [11]

Ēkas (būves) būvētāja (celtniecības ierosinātāja) interese ir jau ēkas būvniecības laikā lietot, valdìt un iegūt augḷus, apgrūtināt ēku ar lietu tiesībām, tātad kḷūt par būvējamās ēkas īpašnieku. Šobrīd būvētājs (būvniecības ierosinātājs) īpašumtiesības iegūst pēc èkas nodošanas ekspluatācijā un savu ìpašumtiesību nostiprināšanas zemesgrāmatā, kas dažkārt dažādu iemeslu dēl turpinās tik ilgi, ka zemes nomas līguma terminšs ir beidzies. Apsverams ir jautājums par minimālā zemes nomas termiṇa pagarināšanu no 10 gadiem līdz 20 gadiem, nnemot vērā, ka būvniecība var ilgt 12 gadus. Tāpat jāpievērš uzmanība tam, ka ir saglabājamas dalīta ìpašuma tiesības, jo ìpašuma tiesības ietver ne tikai tiesības lietot, bet arī atsavināt, apgrūtināt, iznīcināt īpašumu, paturot vērā ipašuma sociālo funkciju, kas ierobežo ỉpašnieku sabiedrības interesēs. 


\section{Secinājumi}

Brīvprātīgais dalītais īpašums rodas, ja starp noteikta zemes gabala ìpašnieku un tā lietotāju tiek noslēgts atlīdzỉbas vai bezatlīdzības zemes gabala lietošanas līgums uz laiku ne mazāku par 10 gadiem, pieškirot tiesības zemes gabala lietotājam būvēt ēku (būvi), reǵistrēt uzcelto èku (būvi) kā patstāvīgu īpašuma objektu un ekspluatēt to.

Tāpēc iekḷaujot būvniecības tiesiskajā regulējumā prasību par to, ka tikai zemesgrāmatā reg̣istrēts nomas līgums ir pamats, lai cita persona veiktu būvniecību attiecīgajā zemes gabalā, tiktu nodrošināta īpašuma sociālās funkcijas realizācija un sabiedrības interešu ievērošana.

Tā kā juridiski ìpašuma tiesības uz ēku, kas uzbūvēta uz citai personai piederošas zemes, būvniecības ierosinātājs iegūst tikai pēc šis ēkas nodošanas ekspluatācijā un īpašumtiesību nostiprināšanas zemesgrāmatā, tad līdz minētajam brīdim būvniecības ierosinātājs ir ēkas (būves) faktiskais valdītājs, kaut Būvniecības likumā tiek saukts par būves īpašnieku.

Izbeidzoties nomas līgumam, izbeidzas arī èkas īpašnieka īpašuma tiesības uz uzcelto ēku, kas ir būtisks apstāklis jautājuma izlemšanā par kopīpašuma tiesību atzī̌̌anu ēkas un zemes īpašniekiem, un šādā situācijā ir diezgan ierobežotas iespējas piemērot Civillikuma normas par izdevumu atlīdzināšanu.

Būvniecības likumā un ar to saistītajos normatīvajos aktos ietvertais regulējums par ēku (būvju) būvniecību uz lietošanā nodota zemes gabala, neprasot nomas tiesību regiistrēšanu zemesgrāmatā būvatḷaujas izsniegšanas brīdī, sarežğì vai pat padara neiespējamu nākotnē mazināt vai izbeigt dalītā īpašuma radīšanu.

\section{NQT \\ Voluntary Shared Ownership Occurrence in the Context of Social Function and Property Building}

\section{Abstract}

Volunteer separated property has evolved since the Civil Law, restored at this time, has developed the Case Law on the plot of land available for use with the right to construct the building as an independent object of property, but there is no single regulatory framework regarding the requirements that should confine itself to the initiator of the construction of the building to the actual possessor of the construction process property and social functions.

Keywords: volunteer split estate, social function, the land lease contract, the actual possessor. 


\section{Literatūra}

1. Augstākās tiesas Senāta Civillietu departamenta 2010. gada 22. decembra spriedums lietā Nr. SKC-250/2010. Iegūts no: http://www.at.gov.lv/files/uploads/files/archive/department1/2010/250-10.pdf

2. Augstākās tiesas Senāta Civillietu departamenta 2008. gada 29. oktobra spriedums lietā Nr. SKC - 354/2008, 9. lpp. Iegūts no: http://www.l2d.lv/v.php?i=954.4

3. Būvniecības likums: LR likums stājies spēkā 2014. g. 1. okt. Latvijas Vēstnesis, Nr. 146 (4952), 2013, 14. pants. Iegūts no: http://www.likumi.lv/doc.php?id=258572

4. Civillikums. Trešā daḷa. Lietu tiesības, LR likums stājies spēkā 1992. g. 1. sept. VV, 41, 20.02.1937.; Ziñotājs, 22, ar grozījumiem, 876. pants.

5. Par atjaunotā Latvijas Republikas 1937. gada Civillikuma ievada, mantojuma tiesību un lietu tiesību daḷas spēkā stāšanās laiku un kārtību: LR likums. Ziṇotājs, 22, 10.06.1993. Iegūts no: http://likumi.lv/doc.php?id=75530

6. Rozenfelds, J. Lietu tiesības. Trešais labotais un papildinātais izdevums. Rīga: Zvaigzne ABC, 2004, 18. lpp.

7. Rozenfelds, J. Lietu tiesības. Rīga: Zvaigzne ABC, 2002, 41. lpp.

8. Rozenfelds, J. Pētījums par Civillikuma Lietu tiesību daḷas pirmās, otrās un trešās dal̦as modernizācijas nepieciešamību. Rīga, 2007. Iegūts no: http://www.tm.gov.lv/lv/ documents_petijumi_civillikuma_modernizacija

9. Rozenfelds, J. Pētījums par Civillikuma Lietu tiesību daḷas (ceturtās, piektās, sestās un septītās nodaḷas) modernizācijas nepieciešamību. Iegūts no: https://www.tm.gov.lv/lv/nozares-politika/ petijumi

10. Rūda, G̦., Līkops, J., Laviṇa, L. Pētījums par nekustamā ìpašuma tiesību regulējumu pēc zemes reformas pabeigšanas - Civillikuma zemes un èku (būvju) nedalämības koncepta pilnīgas ieviešanas problēma. Iegūts no: https://www.tm.gov.lv/lv/nozares-politika/petijumi

11. Švemberga, A. Būt vai nebūt dalītam īpašumam Latvijā. Jurista Vārds, Nr. 49, 2013. g. 3. dec.

12. Vispārīgie būvnoteikumi: MK noteikumi Nr. 500. stājās spēkā 2014. g. 1. okt. Latvijas Vēstnesis, Nr. 191 (5251), 2014. g. 19. aug., 3. punkts. Iegūts no: http://www.likumi.lv/doc.php?id=269069

13. Sociālās, ekonomiskās un kultūras tiesības. Iegūts no: http://www.tiesibsargs.lv/cilvektiesibas/ socialas-un-ekonomiskas-tiesibas/

14. Покровский, И. Основные проблемы гражданского права. ПетрограА, 1917. 191 с. 


\title{
Doktrinālā pieeja domājamās dạ̣as izpratnei kopipašumā
}

\author{
Inga Kudeikina \\ Rīgas Stradiña universitāte, Juridiskā fakultāte, \\ Tiesību zinātñu katedra, Latvija
}

\section{Kopsavilkums}

Raksts veltīts domājamās daḷas - kopīpašuma tiesiskā elementa - izpētei, akcentējot domājamās daḷas vietu un lomu darījumu veikšanā. Domājamā daḷa nosaka kopīpašnieka īpašuma tiesības apjomu kopējā lietā un vienlaikus pati ir civiltiesiskās apgrozības priekšmets. Prakse ir parādījusi vairākas problēmas, kas izriet no kopīpašumu regulējošo tiesību normu piemērošanas: juridiski nekorekti norādīts darījuma priekšmets, zemesgrāmatu ierakstu neatbilstība faktiski veiktajam darijumam. Lai izvērtētu tiesību normu piemērošanas tiesiskumu darïjumos ar nekustamo īpašumu, tās nepieciešams analizēt kopsakarībā ar empīiskiem materiāliem, ievērojot tiesību zinātnieku atziṇas. Šā pētījuma novitāte ir izpētes rakursā - domājamās daḷas institūts aplūkots darījumu veikšanas procesā un darījuma rezultātā iegūto tiesību nostiprināšanā zemesgrāmatā. Pētỉjuma rezultāti ḷauj secināt, ka tiesību normu saturs zināmā mērā piel̦auj atškirīịas interpretācijas, tāpēc dažu problēmjautājumu risināšana iespējama, veicot atbilstīgus grozijumus tiesību aktos.

Atslēgvārdi: darījumi ar domājamo daḷu, domājamā daḷa, kopīpašums.

Izpratnei par kopīpašumu veidojošo elementu, tostarp domājamo daḷu, ir būtiska nozīme kā no teorijas, tā no prakses viedokḷa. İpaši būtisks praktiskais aspekts ir darījumos ar kopīpašumā esošu nekustamo īpašumu. Vienveidīga tiesību normu interpretācija, pamatotas un samērīgas, no tiesību normām izrietošas prasības darījumu koroborācijai zemesgrāmatā sekmē procesuālo ekonomiju un tiesisko kārtību. Pètāmās problēmas aktualitāti nosaka darījumu ar nekustamo īpašumu pastāvīga intensitāte, tiesību attīstība, Latvijas tiesību sistēmai inovatīva normatīvā regulējuma ieviešana publiskajās tiesībās, kopīpašumu regulējošām tiesību normām paliekot pagājušāa gadsimta trīsdesmito gadu redakcijā. 
Realizējot varu pār lietu, īpašuma tiesības konstrukcijai ir būtiskas atškirības no unitāras īpašuma tiesības. Kopīpašuma juridisko dabu raksturo īpašuma tiesības izlietojamības ierobežojumi, t. i., tiesību subjekts nav absolūti brīvs savā rīcībā ar vinam piederošo îpašuma tiesību, bet ir saistits ar citiem îpašuma tiesïbas subjektiem (kopīpašniekiem).

Likumdevējs kopīpašumu ir nodēvējis par apgrūtinājumu, bet nav sniedzis apgrūtinājuma kā tiesiskas parādības skaidrojumu. Apgrūtinājums var tikt interpretēts gan kā tiesību objekta (ḳermeniskas lietas) apgrūtinājums, gan kā ìpašuma tiesības (nemateriālas parādības) apgrūtinājums. Tiesību zinātnieki atzīst, ka kopīpašums Latvijas tiesību izpratnē ir pašas īpašuma tiesības apgrūtinājums: "Civillikumā kopīpašums nav konstruēts kā īpašuma, bet gan kā īpašnieka, resp. kopīpašnieka varas aprobežojums.” [4, 71]

Darba mērḳis ir izpētìt domājamās daḷas kā kopīpašuma tiesiskā sastāva elementu, lai noskaidrotu tās ietekmi uz kopīpašnieku īpašuma tiesības realizēšanu. Tas l̦autu izvērtēt tiesību normu teorētisko atziṇu sasaisti ar praksē izkristalizētām problēmām.

Zinātniskās pētniecības metodes, kas izmantotas mērḳa sasniegšanai, ir analīze, lai noskaidrotu pētāmā objekta struktūru, un logiskā metode, ar kuras palīdzību kopīpašuma struktūras analīzē iegūtie rezultāti ir novērtēti.

Domājamā dal̦a ir kopīpašuma kā tiesību institūta pamatelements. Kopīpašuma domājamā daḷa jāsaprot kā īpašuma tiesības daḷa. Tā savukārt izsaka noteiktas juridiskās iespējas, kas piemīt domājamās daḷas īpašniekam, piemēram, kopīpašuma objekta reālās sadales gadijumā saṇemt tā reālu daḷu. Kamēr kopīpašums nav izbeigts, katra kopīpašnieka domājamā daḷa raksturo tā stāvokli attiecībā pret kopīpašuma objektu kā vienu veselu un vienlaikus nosaka tiesiskās attiecības savstarpēji starp kopīpašniekiem. Starp kopīpašniekiem rodas gan liettiesiskās attiecības, gan veidojas saistības. Autore kā rezumējošu vēlas norādìt tiesību zinātnieka, juridisko zinātṇu doktora Konstantīna Sklovska (К. И. Скцовский) viedokli, ka "daḷa kopipašumā ir lietu tiesība (īpašuma tiesība), un vienlaikus tai piemìt atsevišķas saistību tiesību pazìmes, nosakot noteiktas tiesības un pienākumus attiecībās ar trešajām personām." [8, 221] Saistību tiesību pazīmes pieškir ne daḷas pašas sevi, jo tām ir liettiesiska daba, bet gan darījumi, kurus veic kopīpašnieki.

Secināms, ka kopīpašumā domājamās daḷas apmērs ir ìpašuma tiesības nesējs.

Ievērojot kopīpašuma tiesības būtību un izvērtējot atbilstīgās Civillikuma normas, jāsecina, ka tiesību satura piešḳirums konkrētam tiesību subjektam ir atkarīgs no pēdējam piederošās domājamās daḷas lieluma. Ar domājamo dạı korelē:

- tiesības sañemt labumus, kādus dod kopīpašuma priekšmets (piemēram, tiesibas sañemt nomas maksu);

- pienākums nest zaudējumus, kādi cel̦as kopīpašuma priekšmetam (piemēram, pienākums segt remonta izdevumus);

- pienākums nest uz kopīpašuma priekšmetu attiecināmos apgrūtinājumus, uzturēšanai nepieciešamos izdevumus (piemēram, pienākums maksāt nekustamā īpašuma nodokli, apsaimniekošanas u. c. izdevumus). 
Civillikums neparedz kopīpašnieku solidāru atbildību. Vienīgais starp kopīpašniekiem esošais atbildības veids ir atbildỉba proporcionāli domājamo dạı lielumam. Šo apgalvojumu apstiprinājusi arī tiesu prakse. [1]

Ārpus sasaistes ar domājamo dalı ir šādas kopīpašnieka tiesības, kas kopīpašniekiem pieder vienādā mērā neatkarīgi no domājamās dạ̦as lieluma:

- pirmpirkuma un izpirkuma tiesība (ar izṇēmumu, kas noteikts Civillikuma 1073. panta otrajā daḷā, proti, ja izlietot pirmpirkuma vai izpirkuma tiesības pieteicas reizē vairāki kopīpašnieki, tad viṇi atsavināto daḷu iegūst kopīgi un sadala to savā starpā līdzīgās dạ̣ās, ja paši nevienojas citādi);

- tiesības prasit kopīpašuma izbeigšanu;

- kopīpašnieka rīcības brīiības tiesība par piekrišanas došanu rīcībai ar kopipašuma priekšmetu.

Tieši pēdējā no nosauktajām tiesībām uzskatāmi akumulējas kopīpašuma apgrūtinājumus nesošā daba. Neatkarīgi no domājamās daḷas lieluma, neatkarīgi no savas rīcības motīviem kopīpašnieks vienmēr ir brīvs savā gribas izpausmē dot vai nedot piekrišanu rīcībai ar kopīpašuma priekšmetu. Kopīpašnieka veto tiesība, kas, lai arī nav noteikta likumā expresis verbis, ir kopīpašuma tiesisko seku izpausme. Tādējādi kopīpašniekam, kurš apveltīts ar vismazāko domājamo daḷu, noteiktās situācijās ir tāds pats tiesību apjoms kā citiem. Likums neparedz kopīpašniekiem tiesības kādus jautājumus izlemt ar balsu vairākumu.

Situācijas tiesisko pusi un neiespējamību nodot jautājumu izlemšanu (rīcību ar kopīpašuma priekšmetu) kopīpašnieku vairākumam raksturo domājamās daḷas cēloniskais sakars ar īpašuma tiesības saturu. Īpašuma tiesību kā vienu veselu veido likumā noteikto tiesību un pienākumu summa, kas piešķir to ỉpašniekam absolūtu varas tiesību pār īpašuma objektu. Tā nav sadalāma komponentēs, atsevišḳi nodalot tiesības un pienākumus, to nav iespējams piešḳirt vairākumam vai tiesības sadalīt pēc pieškirto prioritāšu nozīmīguma, piemēram, būvniecības tiesības atseviškị, tiesības gūt aug̣̣us atsevišşi utt. Domājamā daḷa ir īpašuma tiesības virtuālā sadalījuma atspoguḷojums.

Civillikums nenosaka kārtību, kādā izsakāma tiesību nodošana, veidojot kopīpašumu. Saskaņā ar Zemesgrāmatu likuma 49. pantu, nostiprinot zemesgrāmatā vairākām personām nedalīti piederošās tiesības, katrai no viṇām piederošā domājamā daḷa jānoteic skaitliski. [5] Juridiskajā literatūrā vadošais ir viedoklis, ka domājamā dal̦a ir īpašuma tiesỉbas daḷa uz kopējo lietu. Tāda pozīcija izriet no kopīpašuma definīcijas. Šì teorija ir pazīstama kā "tiesību dal̦as" vai "dal̦as no tiesības" teorija. Uzreiz jāatzīmē, ka ne visi tiesību zinātnieki atbalsta šo teoriju. Diskusiju pamatā ir īpašuma tiesības juridiskā daba, proti, uzskats, ka īpašuma tiesība ir absolūta un nedalāma, turklāt trūkst priekšstatu, kã dalāma īpašuma tiesỉba. V. Pletņovs (B. Пıетнёв) uzskata, ka "izpratne par domājamās daḷas būtību kā subjektīvās īpašuma tiesības daḷu nav pieṇemama, jo subjektīva tiesība nevar tikt sadalīta daḷās. Tā vai nu ir, vai tās nav". [6, 292] Tik kategoriskam uzstādījumam nav pamata. Kopīpašuma tiesība savu dzīvotspēju ir pierādījusi. Apstāklis, ka kopīpašuma tiesība ir sarežgìita juridiska konstrukcija un darījumos prasa 
daudzpakāpju izlietošanu, nevar kalpot par pamatu kopīpašuma noliegšanai. Jāsaprot, ka īpašuma tiesības apjoms netiek nošķirts vai nodalìts tiesību subjektiem, to "horizontāli" sadala starp vairākiem nesējiem, îpašuma tiesībai paliekot nedalītai.

Domājamās daḷas kā tiesību institūta satura atklāšana nebūtu pilnīga, neapskatot teoriju par lietas domājamo dalı. Ievērojamais tiesību zinātnieks Dmitrijs Meijers (А. И. Мейер) vēl 19. gs., raksturojot kopīpašumu, norādīja, ka kopīpašuma tiesība ietver lietas nedalāmību, bet ne tajā nozīmē, ka lietu nevarētu fiziski sadalìt, bet gan tāpēc, ka katrā no kopējās lietas dalininām akumulējas (savienojas) katram no kopīpašniekiem piederošā īpašuma tiesība. Tātad, ja lietas katrā atomā (lietas dalıā) ikvienam no kopīpašniekiem pieder kāda domājamā dạ̧a, tad tāda pati daḷa ikvienam no kopīpašniekiem pieder arī veselā lietā. Bet nav iespējams nodalìt, kāda tieši lietas reālā daḷa pieder kopīpašniekam. $[7,284]$ Domājamā dal̦a ir īpašuma tiesības objekts kopīpašumā. Domājamā dal̦a ir individuāli noteikta, tā ietver materiālas lietas ideālu dalıu, uz kuru ekskluzīvas tiesības ir individuāli noteiktam subjektam, un galvenais - uz kuru citiem kopīpašniekiem nav tiesību.

Īpašuma tiesības sadalījuma domājamās daḷās pierakstam un praktiskajai izteikšanai izmanto dạ̦skaitli, jo tas ir skaitlis, kas raksturo kādu noteiktu dạ̦u no viena veseluma. Skaitlis virs daḷsvìtras apzīmē daḷu skaitu, bet skaitlis zem dạ̦svitras - dal̦as lielumu. Šādā veidā īpašuma tiesība var tikt sadalīta starp neierobežotu skaitu tiesību subjektu, jo skaitli "1" var izteikt kā daḷskaitli ar jebkuru skaitli saucējā, piemēram, $1=4 / 4=20 / 20=110 / 110=3000 / 3000$ un tamlīdzīgi.

Vienu veselu, piemēram, sadalot divās dạ̦ās, iegūstam divas vienādas daḷas, ko pieraksta šādi: $1 / 2$ un $1 \frac{1}{2}$. Tas nozìmē, ka îpašuma tiesỉba pieder diviem tiesību subjektiem vienādās dạās. Darījumos īpašuma tiesības sadalījums domājamās dạ̦ās ir atkarīgs tikai no līdzēju gribas, no tā, cik lielu tiesības daḷu nekustamā īpašuma īpašnieks darījuma rezultātā nodod citam tiesību subjektam. Būtiski ir atzīmēt, ka šis sadalījums neattiecas uz īpašuma tiesības objektu. Tas netiek sadalìts reālās dạās un paliek kā viena lieta. Kopīpašuma domājamā dal̦a, kā tika noskaidrots, ir virtuāls lielums, kas nav piesaistìts kopīpašuma objekta reālai dal̦ai. Tas izriet arī no Civillikuma 1067. panta pirmajā dạ̦ā dotās kopīpašuma definīcijas.

Domājamā dạ̣a ir ne tikai tiesību un pienākumu mērs kopīpašumā, bet arī patstāvīgs civilās apgrozības priekšmets. Šĩ tēze atspoguḷota ne tikai civiltiesību teorijā [3, 57], bet savu apstiprinājumu guvusi arī judikatūrā: "Katra kopīpašnieka domājamā dạ̦a kopīpašumā ir patstāvīgs civilās apgrozỉbas priekšmets, un domājamās daḷas atsavināšanai un maiṇas līguma noslēgšanai vai domājamās daḷas ieḳilāšanai līdzīpašnieku piekrišana nav vajadzīga, ja vien šāda rīcība neattiecas uz pārējo kopīpašnieku daḷām (Civillikuma 1072. un 1073. pants, Latvijas Republikas Augstākās tiesas Senāta lietas SKC-58/1999 un 1235/2009). [1]

Domājamo dalı pieraksts līgumos un zemesgrāmatā nav vienāds.

Apskatot zemesgrāmatu ierakstus par domājamās daḷas ieḳīāšanu, ir redzams, ka zemesgrāmatu tiesneši aizliegumu ierakstus, kas saistīti un attiecas uz domājamās daḷas ieḳīlǎšanu, veic divējādi. Vienā variantā šãdi: "domājamās dalas īpašniekam E. M., personas kods .., noteikts aizliegums bez AS .., nodokḷu maksātāja kods .., nekustamo 
īpašumu atsavināt, dāvināt, sadalīt un apgrūtināt ar lietu tiesībām". Šajā pat folijā ir sastopams arī otrs variants: "noteikts aizliegums bez .., nodokḷ maksātāja kods .., rakstiskas piekrišanas atsavināt, dāvināt, sadalìt un apgrūtināt ar lietu tiesībām A. P., personas kods .. piederošo domājamo dalı"u”.[2]

Abu ierakstu veidu salīdzinājums atklāj pirmā varianta trūkumus. Kopīpašuma gadījumā kopīpašnieks ir tiesīgs iekīlāt viṇam piederošo domājamo dạıu (un nevis nekustamo īpašumu). Tas izriet no Civillikuma 1072. panta. Jāuzsver, ka tieši domājamā daḷa ir darījuma priekšmets ḳilas darỉjumos, kur kopīpašnieks ieḳilā viṇam piederošo domājamo dalıu, tāpēc absolūti nav pamata attiecināt aizliegumu, kas izriet no hipotēkas, uz visu nekustamo īpašumu. Šāds ieraksts ir maldinošs, neatbilstīgs likumam un faktiskajiem apstākḷiem.

\section{Secinājumi}

1) Domājamās daḷas vērtība tiek izteikta ar dậskaitli un tā atspoguḷo īpašuma tiesības satura sadalïjumu starp vairākiem tiesību subjektiem.

2) kopīpašuma tiesība izveidojas, tiesību subjektam dạ̣ēji atsakoties no savām tiesībām par labu citiem tiesību subjektiem un daḷēji delegéjot savus pienākumus citiem tiesību subjektiem, - kas tiek izteikts ar domājamās dal̦as palīdzību.

3) Domājamā daḷa ir virtuāls lielums, kas nav piesaistīts kopīpašuma priekšmeta reālai daḷai, un tās matemātiskā vērtība var nesakrist ar ekonomisko vērtību.

4) Ir sastopami gadījumi, ka darījumos ar kopīpašuma domājamām dal̦ām darījuma priekšmeta formulējums ir neatbilstīgs normatīvo aktu prasībām.

5) Kopīpašnieku tiesības un pienākumi iedalās tādos, kas korelē ar kopīpašniekam piederošo domājamo dalı skaitu, un tādos, kas nav atkarīgi no domājamo daḷu skaita.

Situācijas modernizācijai atbilstīgi mūsdienu juridiskās domas tendencēm un tiesību attīstības perspektīvām Civillikumā būtu nepieciešams lietot tiesiski pamatotu terminologiiju, izvērsti reglamentēt kopīpašnieku tiesības un pienākumus attiecībā uz domājamo daḷu kā patstāvīgu civilās apgrozības priekšmetu.

\section{NVL \\ Doctrinal Approach to the Understanding of Undivided Interest in Respect to Co-ownership}

\section{Abstract}

The article is devoted to the research of undivided interest as a legal component of co-ownership, specifically focusing on its place and role in transactions. Undivided interest determines the scope of co-owners' property rights in the common property, 
meanwhile being a target of civil transactions. Practice has unveiled several problems arising from the application of co-ownership laws: legally incorrect subject of the transaction, Land Registry entries failing to show the actual transaction. With a view to analysing the validity of legal treatment in real estate transactions, laws should be viewed in conjunction with empirical materials, taking into consideration the opinions of legal scholars. The novelty of the study is its perspective, i.e. the institution of undivided interest is viewed from the standpoint of transactions and the registration of the title obtained as a result of transactions with the Land Registry. The results of the study give strong grounds to conclude that the contents of laws, to some extent, leave room for interpretation; therefore, certain outstanding problems could be solved by making relevant amendments to the law. interest.

Keywords: co-ownership, undivided interest, transactions involving undivided

\section{Literatūra}

1. Latvijas Republikas Augstākā tiesa. Kopīpašums. Tiesu prakses apkopojums [skatīts 07.03.2014.]. Iegūts no: http://at.gov.lv/files/uploads/files/docs/2011/kopipasums.doc

2. Rìgas pilsētas zemesgrāmatas nodalījums Nr. 6123, [skatīts 07.03.2014.]. Iegūts no: www.zemesgramata.lv

3. Rozenfelds, J. Lietu tiesības. Rīga: Zvaigzne ABC, 2004. 308 lpp.

4. Sinaiskis, V. Latvijas civiltiesību apskats: Lietu tiesības: Saistību tiesības. Rīga: Latvijas Republikas Tieslietu ministrijas Tiesiskās informācijas centrs, 1996, 246. lpp.

5. Zemesgrāmatu likums. Latvijas Republikas likums, pieṇemts 1937. g. 22. dec., stājās spēkā 1993. g. 5. apr. Latvijas Vēstnesis, Nr. 11, 1993. g. 8. apr.

6. ГражАанское право. Учебник для вузов. Часть первая / под общ. реА. Т. И. Икиарионовой, Б. М, Гонгало, В. А. Плетнёва. Москва, 2001. 292 с.

7. Мейер, А. И. Русское гражданское право. СПб., 1902. 284 с.

8. Скмовский, К. И. Применение гражданского законодательства в отношениях с иными участниками. Москва, 1997. 350 с.

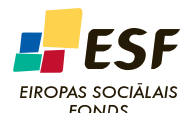
FONDS
IEGULDĪJUMS TAVĀ NĀKOTNĒ

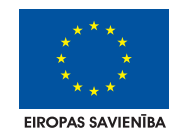

Raksts sagatavots ar ESF projekta "Atbalsts doktorantiem studiju programmas apguvei un zinātniskā grāda ieguvei Rīgas Stradiṇa universitātē", vienošanās

Nr. 2009/0147/1DP/1.1.2.1.2/09/IPIA/VIAA/009 atbalstu. 


\title{
Valsts un pašvaldības kompetence sabiedriskās kārtības nodrošināšanā publiskos pasākumos
}

\author{
Kristine Kuznecova \\ Rīgas Stradiña universitāte, Juridiskā fakultāte, Latvija \\ Valsts policijas koledža, Latvija
}

\section{Kopsavilkums}

Arvien aktuālāki kḷūst jautājumi par valsts un pašvaldības institūciju kompetenci sabiedriskās kārtības un drošības garantēšanā publisku pasākumu laikā. Tiesību aizsardzības iestādēm viens no svarīgākajiem uzdevumiem ir sabiedriskās kārtības un drošības garantēšana šo pasākumu norises vietās. Lai arī būtiska loma tās nodrošināšanā ir atvēlēta pašvaldību institūcijām (pašvaldības policija šobrīd ir viens no nozīmīgākajiem Valsts policijas sadarbības partneriem policijas funkciju pildīšanā), praksē novērojamas vairākas problēmas. Pirmkārt, vai valsts un pašvaldïbas policijas iestādēm ir pietiekami materiāltehniskie un cilvēkresursi, lai garantētu sabiedrisko kārtỉbu liela mēroga (arī paaugstināta riska) publiskos pasākumos? Otrkārt, vai šo iestāžu darbinieki publisku pasākumu laikā izmanto samērīgus tiesiskos līdzekḷus, lai vērstos pret sabiedriskās kārtības pārkāpējiem?

Atslēgvārdi: publiski pasākumi, sabiedriskās kārtības un drošības garantēšana.

\section{Raksta mērḳis}

Raksta mērḳis ir izpētìt valsts un pašvaldības iestāžu kompetences apjomu, garantējot sabiedrisko kārtību publisku pasākumu laikā. Termini "sabiedriskā kārtība", "sabiedriska vieta", "publisks pasākums" šajā rakstā saturiski sīkāk netiks analizēti. Rakstā valsts un pašvaldības kompetence, garantējot sabiedrisko kārtību publisku pasākumu laikā, tiks skatīta atbilstīgi Publisku izklaides un svētku pasākumu drošības likumā noteiktajam "publiskas vietas" un "publiska pasākuma" definējumam [3, 1. pants]. Šajā publikācijā autore vēlas noškirt likumā "Par sapulcēm, gājieniem un piketiem" noteiktās un valsts garantētās un aizsargātās miermīlīgās pulcēšanās brīivibas izpausmes - sapulces, gājienus un piketus. 


\section{Rezultāti}

Demokrātijas stabilitātes jeb izmaiṇu un stabilitātes paradoksa problēmu var uzskatīt par centrālo jaunu politisko sistēmu veidošanās gadījumos. G. Ozolzīle norāda $[15,41]$, ka ar jēdzienu "jauna politiska sistēma" ir jāsaprot tāda sistēma, kas atrodas veidošanās (aut. piezīme - pilnveidošanās) procesā, un par tādu šobrīd var uzskatīt arī Latvijas sistēmu. Demokrātijas stabilitātes jēdziens politikas zinātnē tiek izmantots bieži, bet jāatzīst, ka tā aprises ir izplūdušas. Lielākoties tas tiek saprasts visai šauri un mehāniski - kā valdību stabilitāte. Dažās situācijās demokrātijas stabilitātes jēdziens tiek skatīts plaši un nekonkrēti - kā visas politiskās sistēmas stabilitāte. Jāpiekrīt A. Lijphartam (A. Lijphart) [13, 217], kas demokrātisko stabilitāti iztirzā plašākā nozīmē un ietver tajā arī pilsonisko kārtību un drošỉbu, zemu vardarbības līmeni, valsts pārvaldes sistēmas leg̣itimitāti un efektivitāti.

Lai gan Latvija ir iestājusies Eiropas Savienībā, iekḷāvusies Šengenas zonā un vērojama ekonomiskā cikliskuma augšupeja pēdējos gados [8, 3], pēc autores domām, Latvijā joprojām pastāv virkne nopietnu šḳēršlu demokrātiskās stabilitātes pastāvēšanai. Minētais vistiešākajā veidā ietekmē arī sabiedriskās kārtības un drošības garantēšanas jomu publisku pasākumu laikā. Arvien biežāk Latvijas pilsētās, novados un pagastos tiek rīkoti publiskie pasākumi, t. sk. sporta pasākumi, kuros vienuviet pulcējas liels cilvēku skaits ar dažādu sociālās spriedzes līmeni. Var gadīties, ka dažādu apstākḷu ietekmē publisks pasākums no sākotnēji miermīlīga var pārvērsties par enerǵijas avotu agresīvu cilvēku pūlim, kura darbība pāraug vardarbībā, demolēšanā, mantas bojāšanā, sabiedrībā pieṇemto uzvedības noteikumu un tiesību normu ignorēšanā. Šādas situācijas ne tikai negatīvi ietekmē sabiedrības drošỉbu kopumā, bet, iespējams, pat rada apdraudējumu valsts drošībai tajos gadījumos, ja izcel̦as plaša mēroga masu nekārtības (nemieri) dažādu izklaides pasākumu vai sporta spẹlı laikā, vai masu nekārtības ir saistìtas ar šo pasākumu norisi. Tādēl vēlreiz jāuzsver nepieciešamība policijas iestādēm būt gatavām novērst un pārtraukt šādas situācijas, izmantojot visus pieejamos tiesiskos lìdzekḷus.

Demokrātijas stabilitātes pastāvēšanas process, kā norādīts iepriekš, nav iedomājams bez centieniem nodrošināt likumību un tiesību aizsardzību no valsts puses. Tāpat tas nav iedomājams bez iedzīvotāju apzinātas nepieciešamības pildīt pienākumus. Viens no nepieciešamākajiem un pirmajiem valsts uzdevumiem ir kārtības un drošības garantēšana valstī, personu un vinu likumīgo darbību aizsardzība pret varbūtējiem draudiem un uzbrukumiem. Raksta tēmas ietvaros, neapšaubāmi, autores interesi izraisa viena no svarīgākajām valsts funkcijām - policejiskā funkcija - sabiedriskās kārtības un sabiedrības drošības garantēšana valstī. Atbilstīgi likuma "Par policiju" 1.-3. pantā minētajam, policija ir apbruṇota, militarizēta valsts vai pašvaldības institūcija, tātad valsts pārvaldes institūcija, kuras uzdevums ir nodrošināt sabiedrisko kārtību un mieru, sekmēt sabiedrības veselību, drošỉbu, tikumību, kā arī nodrošināt noziegumu novēršanu un atklāšanu, vainīgo personu saukšanu pie atbildības. [2] Papildus jānorāda, 
ka policijas uzdevumus sabiedriskās kārtības un drošības garantēšanā nedrīkst skatīt atrauti no diviem aspektiem. Pirmkārt, policijas darbības prioritātes nosaka sabiedrība, tādēl policijas uzdevumiem ir jābūt noteiktiem atbilstoši sabiedrības interesēm. Otrkārt, policijas darbībai ir jābūt vērstai uz valsts un pašvaldỉbas institūciju lēmumu realizāciju.

Policijas darbība mūsdienu demokrātiskā sabiedrībā tiek vērtēta atbilstoši tam, cik efektīvi tiek uzturēta sabiedrības drošība, vienlaikus aizsargājot personu tiesības un brīvības. To garantēšana ir universāls policijas pozitīvās lomas vērtēšanas kritērijs visās sabiedrisko attiecību jomās. Tiesību aizsardzības iestāžu un citu par sabiedrisko kārtību atbildīgo iestāžu pienākums ir nodrošināt Satversmē noteiktās konstitucionālās tiesības un brīvības: "Valsts atzīst un aizsargā cilvēka pamattiesības saskaṇā ar šo Satversmi, likumiem un Latvijai saistošiem starptautiskajiem līgumiem" [1, 89. pants]. Minētais valsts uzdevums kḷūst krietni sarežgitīāks, ja publisku pasākumu norises vietās vienkopus pulcējas liels cilvēku skaits ar mērḳi realizēt savas likumā noteiktās tiesības un brīvības, piemēram, realizēt Satversmes 100. pantā noteikto, ka "ikvienam ir tiesības uz vārda brīivibu, kas ietver tiesības brīvi iegūt, paturēt un izplatìt informāciju, paust savus uzskatus" $[1,100$. pants $]$.

Valsts politiku noziedzības apkarošanas un sabiedriskās kārtības un drošības aizsardzībā, kā arī personu tiesību un likumīgo interešu aizsardzībā Latvijā atbilstīgi kompetencei issteno Valsts policija $[6,1$. punkts]. Policijas darbinieka pamatpienākumus sabiedriskās kārtības nodrošināšanas jomā noteic likuma "Par policiju" 10. pants: “. nodrošināt kārtību uz celiiem, ielās, laukumos, parkos, sabiedriskā transporta līdzekḷos, lidostās, ostās, stacijās un citās publiskās vietās, lai garantētu personu un sabiedrības drošību; novērst un pārtraukt administratīvos pārkāpumus, noskaidrot vainīgos, savas kompetences ietvaros sastādìt protokolus .." [2, 10. punkts]. Valsts policijā pēc pastāvošā iekšējā funkcionālā sadalỉjuma kriminālpolicijas struktūrvienības nodrošina noziedzìgu nodarījumu atklāšanu, novēršanu un noziedzīgus nodarījumus izdarījušu personu meklēšanu $[12,155]$, savukārt sabiedriskās kārtības nodrošināšana, satiksmes uzraudzība un, neapšaubāmi, klasiskajā izpratnē prevencija (lat. pravevenire aizsteigties priekšā) ir kārtības policijas prerogatīva.

Ar Valsts policijas 2010. gada 22. februāra noteikumiem Nr. 5 "Dienesta pienākumu izpildes organizācija un kontrole sabiedriskās kārtības nodrošināšanas un satiksmes uzraudzības jomā" noteikts, ka sabiedrisko kārtību un satiksmes uzraudzỉbu - atbilstīgi savai kompetencei - nodrošina Valsts policijas kārtỉbas policijas struktūrvienības. Tās ir patruḷdienests, satiksmes uzraudzības struktūrvienības, kārtības policijas inspektori (iecirkṇa inspektori, nepilngadīgo lietu inspektori), operatīvās vadības struktūrvienības, konvoja dienests, aț̣auju sistēma un objektu apsardze. Šìs ir kārtības policijas jomas un pamatpienākumi, kas skar sabiedriskās kārtības nodrošināšanu, likumpārkāpumu novēršanu un atklāšanu. To galvenais uzdevums ir, veicot sabiedriskās kārtības nodrošināšanu vai satiksmes uzraudzību, panākt likumpārkāpumu novēršanu, kā arī satiksmes negadijumu un tajos cietušo personu skaita samazināšanos. [7] 
Saskaṇā ar Publisku izklaides un svētku pasākumu drošỉbas likumā noteikto par kārtỉbas uzturēšanu publisku pasākumu laikā ir atbildīga Valsts policija vai pašvaldības policija, Zemessardze, kā arī juridiskā persona, kurai izsniegta licence apsardzes darbỉbas veikšanai un ar kuru pasākuma organizators ir noslēdzis līgumu par sabiedriskās kārtības un drošības, kā arī ugunsdrošības prasību izpildi pasākuma laikā. Uzdevumu izpildi sabiedriskās kārtības nodrošināšanas, likumpārkāpumu novēršanas un satiksmes uzraudzības jomā publisku pasākumu laikā primāri nodrošina reǵionālās pārvaldes kārtības policijas patruḷpolicijas amatpersonas, to skaitā arī tās amatpersonas, kuras dienesta pienākumu izpildi veic satiksmes uzraudzības jomā.

Vērtējot Valsts policijas personālresursus, to spēju garantēt kārtību publisku pasākumu laikā, jāsecina, ka dažās situācijās resursi ir ierobežoti. Uzdevumu izpildes kvalitāti sabiedriskās kārtības garantēšanā publisku pasākumu laikā būtiski kavē neaizpildītās vakances: šobrīd Valsts policijā ir apmēram 1670 patrulpolicijas un satiksmes uzraudzības amatpersonas, bet faktiski dienesta pienākumu izpildē ir iesaistitas 420 amatpersonas, un vakanto amatu vietu skaits ir 240. [9] Sniedzot atbalsta funkcijas sabiedriskās kārtības nodrošināšanā masu pasākumos ārkārtas un krīzes situācijās, dienesta pienākumu izpildē ir iesaistītas apmēram 150 patruḷpolicijas Speciālo uzdevumu bataljona amatpersonas. N̦emot vērā, ka lielākoties visas kārtības policijas struktūrvienības ir ievērojami nenokomplektētas, realitātē jāsaskaras ar situācijām, ka patrulppolicijas amatpersonas tiek iesaistītas citu uzdevumu izpildē, nevis savu tiešo pamatfunkciju veikšanā, proti, sabiedriskās kārtības nodrošināšanā.

Valsts policijas darbību sabiedriskās kārtības un drošības garantēšanā publisku pasākumu laikā var iedalīt trīs posmos: sagatavošanās, izpilde un noslēgums.

Pirmajā, sagatavošanās posmā, Valsts policijas kārtības policijas priekšnieks, saṇemot uzdevumu par sabiedriskās kārtības nodrošināšanu publiska pasākuma laikā, novērtē situāciju, iegūstot (pieprasot) informāciju par pasākuma saturu, tā dalībniekiem, nolūkiem un norisi, tad viņš noteiktā kārtībā par pasākuma pieteikumu informē Valsts policijas Galvenās kārtības policijas pārvaldi. Tāpat kārtības policijas priekšnieks organizē un veic apdraudējuma risku analīzi (mērḳtiecīga papildu informācijas ieguve par iespējamiem sabiedriskās kārtības pārkāpumiem konkrētajā pasākumā) un organizē plāna izstrādi par sabiedriskas kārtības nodrošināšanu, norīkojot par plāna izstrādi atbildīgo amatpersonu un personīgi kontrolējot izstrādes gaitu. Sagatavošanās posmā tiek organizēti personālsastāva un tehnisko lìdzekḷu sagatavošanas pasākumi. Lai darbu sekmīgi veiktu, notiek teritorijas un objektu apsekošana kopā ar organizatoriem. Tāpat notiek norīkojumā nosūtîto darbinieku un amatpersonu dienesta instruktāža, tiek organizēta visu atbildīgo institūciju un dienestu sadarbība. Bieži vien grandiozu un plašu publisku pasākumu laikā tiek izveidoti operatĩvie vadības štābi, kuri nepieciešami visu darbību koordinēšanai un realizācijai.

Izpildes posms aptver laiku no sabiedriskās kārtības nodrošināšanā iesaistīto spēku pienākumu izpildes sākuma un turpinās līdz tā pabeigšanai. Šajā posmā tiek organizēta dienestu un norīkojumu vadība, noteikti transporta un gājēju kustības 
ierobežojumi, nodrošināts caurlaižu režīms kontroles posteņos. Policijas galvenais uzdevums publiska pasākuma laikā, saskaņā ar Pārvaldes priekšnieka apstiprinātu plānu, ir nodrošināt sabiedrisko drošîbu un kārtību publiskā pasākumā. Līdz ar to policijai ir tiesības aizliegt ienest publisko pasākumu norises vietās jebkādus dzērienus stikla vai citā plīstošã iepakojumā, neielaist pasākuma norises vietā iereibušas personas, kā arī personas bez biḷetēm, ieejas kartēm vai caurlaidēm, par sīkiem pārkāpumiem brīdināt pārkāpumu izdarītājus, neizraisot konflikta situācijas. Tāpat policijai ir tiesības aizturēt pasākuma laikā noklīdušus bērnus, ja iespējams, noskaidrot vinu vārdu, uzvārdu un organizēt bērnu nodošanu attiecīgām amatpersonām, veikt pasākumus, lai sabiedriskās kārtības grupveida pārkāpumus pārtrauktu jau sākuma stadijā, aizturēt nekārtību izraisītājus un aktīvos dalībniekus, neizraisot situācijas saasināšanos. Šajā posmā vadība kontrolē rīkojumu un komandu izpildi, kā arī norit visu atbildīgo iestāžu cieša sadarbība.

Noslēguma posms sākas ar pasākuma pabeigšanas brīdi un beidzas, kad pasākuma apmeklētāji izklīst. Šajā posmā tiek atcelti ieviestie ierobežojumi, pilnā apjomā atjaunots pārtrauktais transporta un dažu uzṇēmumu darbs. Pasākuma noslēguma posmā policijas darbinieka pienākums ir brīdināt dalībniekus/skatītājus nedrūzmēties pie galvenajām izejas vietām un norādìt papildu izejas. Pēc pasākuma noslēgšanas dienesta pienākumu izpildi drīkst beigt tikai ar priekšnieka (komandiera) aț̣auju, ja tas nav atrunāts citādāk. Noslēguma posmā tiek veikts rezultātu apkopojums un dots kopējais vērtējums. Nopietnu pārkāpumu gadỉjumos, kas varētu ietekmēt sabiedrības drošību kopumā citu publisku pasākumu laikā, tiek sagatavota informācija un nosūtīta vietējai pašvaldībai vai pasākumu organizatoriem. [14, 59]

Analizējot policijas norīkojumu vai faktisko sabiedriskās kārtības nodrošināšanā iesaistīto policijas darbinieku pienākumus sagatavošanās, izpildes un noslēguma posmos, jāsecina, ka pienākumu izpilde sākas ar brīdi, kad tiek saṇemts uzdevums. Plānā par sabiedriskās kārtības un ceḷu satiksmes drošības garantēšanu ir jāparedz pasākuma nodrošināšanas galvenie uzdevumi, publiskā pasākuma vieta, laiks un norises kārtība, policijas darbinieku pienākumi pasākuma laikā, par uzdevumu izpildi atbildīgās personas, sakaru organizācija, ekipējums, instruktāžas un dienesta sākuma laiks. Policijas darbinieku uzdevumi publisku pasākumu laikā, kā tika norādīts iepriekš, ir nodrošināt publisko pasākumu dalïbniekiem noteikto uzvedības normu stingru ievērošanu, sniegt atbalstu un palīdzību valsts un pašvaldību iestādēm, pasākumu organizētājiem, lai sekmētu pasākumu norisi, laikus novērst un atklāt noziedzīgus nodarījumus, sabiedriskās kārtības noteikumu pārkāpumus publisku pasākumu norises vietās. Policijas darbinieks ir tiesīgs dot saistošus norādījumus pasākuma organizatoram, vadītājam, dalībniekiem un kārtības uzturētājiem, lai nodrošinātu sabiedrisko kārtību un nepiel̦autu sabiedriskās kārtības pārkāpumus.

Aplūkojot ārvalstu policijas iestāžu pieredzi sabiedriskās kārtības garantēšanā publisku pasākumu laikā, autores interesi piesaistīja Nīderlandes policijas prakse. Lai nodrošinātu sabiedrisko kārtību publiskos pasākumos, Nīderlandes policija darba 
pamatā izvirzījusi vairākus principus: aizsargāt indivīda tiesības uz vārda brīvību un pulcēšanos, cieši kontaktēt un uzturēt dialogu ar sabiedrību, panākt sabiedrības uzticēšanos valsts pārvaldei un policijai, gādāt par policijas darbinieku profesionalitāti, policijas darbības nepārtrauktību, vardarbības draudu novēršanu. [17] Lai nodrošinātu šeit minēto principu realizāciju, Nīderlandes policija ir izveidojusi Miera vienību (Peace Unit), kuras uzdevums ir veikt laikus un nepārtrauktu komunikāciju ar publiska pasākuma dalībniekiem, uzturēt kontaktus ar pasākuma riska grupām, novērst vardarbības draudus. [18, 14] Miera vienības darbinieki publiska pasākuma laikā pārvietojas kājām, viṇi uzrunā publiska pasākuma dalībniekus un ir sasniedzami. Darbinieku izskats ir neuzkrītošs, viṇi nav apbruṇoti un nav tērpušies speciālajā ekipējumā, tādā veidā neradot papildu satraukumu vai agresiju pasākuma dalībnieku vidū. Miera vienība visu pasākuma laiku uztur kontaktus ar citām policijas vienībām, maksimāli nodrošinot iespēju izvairīties no sabiedriskās kārtības grupveida pārkāpumiem. Tā tiek salīdzināta ar policijas "acīm un ausīm", bet nepieciešamības gadījumā, kad jānovērš vai jāpārtrauc sabiedriskās kārtības pārkāpumi (vai nekārtības), ir gatava un iesaistās masu nekārtību novēršanas vienība (Squad), kura atrodas netālu.

Šis raksts l̦auj secināt, ka sabiedriskās kārtības un drošības garantēšanas funkcijas publiska pasākuma laikā pamatā īsteno Valsts policija, tomēr jāatzīst, ka būtiska loma procesā ir atvēlēta arī vietējo pašvaldỉbu institūcijām - subjektiem, kas atbildīgi par vietējo iedzīvotāju sociālo un fizisko drošîbu. Saskañā ar likuma "Par pašvaldībām" 15. panta pirmās dal̦as 12. punktu viena no pašvaldību autonomām funkcijām ir dalība sabiedriskās kārtības nodrošināšanā, žūpības un netiklỉbas apkarošanā. Pašvaldībām autonomo funkciju îstenošanā zināmā mērā ir rīcības brīvība. Minētās funkcijas var tikt ìstenotas dažādos veidos un dažādos līmen,os: izveidojot pašvaldỉbas administratīvo komisiju un/vai pašvaldības policiju, izveidojot pašvaldībā sabiedriskās kārtības sargu amatus, pilnvarojot pašvaldības amatpersonas kontrolēt saistošo noteikumu izpildi un piemērot sodus par to pārkāpšanu, sniedzot atbalstu tiesību aizsardzības iestādēm. Šo autonomo funkciju ĩstenošana pašvaldībām vienlaikus piešḳir ne tikai lēmumu iniciatīvas tiesības, lēmumu pieñemšanas un ìstenošanas brīvỉbu, bet arī noteiktu atbildỉbu par šo funkciju îstenošanu. Tas nozīmē, ja, piemēram, pašvaldība organizē vai izsniedz atḷaujas rīkot publiskus pasākumus (izklaides sarīkojumus, sporta sacensības), tad tai ir tiesības un arī pienākums iniciēt un patstāvīgi pieṇemt lēmumu par sabiedriskās kārtības nodrošināšanu savā teritorijā to īstenos policija, kuras pārraudzībā ir pašvaldỉbas teritorija, sabiedrisko kārtību nodrošinās pašvaldības izveidota pašvaldības policija vai to veiks privātie apsardzes uzñēmumi. [11, 336]

Likuma "Par policiju" 19. pants noteic, ka pašvaldỉba var izveidot pašvaldỉbas policiju vai Valsts pārvaldes iekārtas likumā noteiktajā kārtībā delegèt uzdevumu izpildi citai pašvaldībai. Tiesību norma, kas ḷauj pašvaldībām izveidot pašvaldības policiju, pieškirir tiesības, bet neuzliek pienākumu veidot savā administratīvajā teritorijā pašvaldỉbas policiju. 
Atbilstīgi likuma "Par policiju" 19. pantā noteiktajam, pašvaldības policijas darbinieku pienākumos ietilpst "likumpārkāpumu profilakse, kontrole par to, kā tiek izpildīti pašvaldību apstiprinātie noteikumi, par kuru pārkāpšanu paredzēta administratĩvā atbildība, Valsts policijas un Drošỉbas policijas atbalstî̌sana sabiedrības drošības garantēšanā un noziedzības apkarošanā” [2, 19. pants]. Pašvaldības policijas lomu sabiedriskās kārtības nodrošināšanā uzskatāmi atspoguḷo Ventspils pašvaldības policijas darbības rezultāti. Ventspils pilsētas pašvaldības policija tika izveidota 1992. gada 26. oktobrī saskañā ar likuma "Par policiju" 19. pantu un pamatojoties uz Ventspils pilsētas Tautas deputātu padomes valdes lēmumu. Ventspils pašvaldības policija gadu gaitā ir uzṇēmusies arvien vairāk funkciju, kuru izpildi Valsts policija resursu trūkumu dēl nespēj nodrošināt vai ir pārtraukusi pildīt. Pašvaldības policijā strādā 60 pašvaldības policijas darbinieki. Tikai pašvaldības policijai Ventspils administratīvajā teritorijā ir patruḷdienests (3-4 patruḷu grupas diennaktī) ar patrulēšanas intensitāti vienai mobilajai patrulas grupai $300-400 \mathrm{~km}$ diennaktī. Pašvaldības policija apkalpo gandrīz visus pilsētas iedzīvotāju izsaukumus (vidēji 4500 izsaukumu gadā). Daḷa Valsts policijā saṇemto izsaukumu tiek pāradresēti pašvaldības policijai. Ventspils pašvaldības policija nodrošina sabiedrisko kārtību sporta, kultūras un citos pasākumos (vidēji gadā ap 150). Valsts policija šajos sarīkojumos piedalās tikai cel̦u satiksmes ierobežošanā. Pašvaldības policija ir atbildīga par pilsētas pludmales glābšanas dienesta darba organizēšanu peldsezonas laikā, to 2012. gadā nodrošināja 10 glābēji, kuru rīcībā ir iegādāts atbilstīgs moderns ekipējums (glābšanas motorlaiva u. c.). [19]

Sabiedriskās kārtības un drošỉbas joma publisku pasākumu laikā nenoliedzami var būt saistīta ar dažādām ārkārtas situācijām stihisku nelaimju, ugunsgrēku, rūpniecisko avāriju, katastrofu un epidēmiju gadījumā. Sabiedriskās kārtības un drošības kopējais elements ir fokusēšanās uz indivīdu personisko (fizisko) drošību, aizsardzību no dažādiem apdraudējumiem arī civilās drošības jomā. Būtisks jautājums, kuru autore vēlas iztirzāt, ir Zemessardzes loma sabiedriskās kārtības un drošības garantēšanā publisku pasākumu laikā. N̦emot vērā nemilitāro draudu izteikto dominanci pār militārajiem, zemessargiem ir noteikta l̦oti nozīmīga vieta atbalsta sniegšanā valsts aizsardzības civilajai komponentei. Pamatojoties uz ìpaši izstrādātu tiesisko regulējumu, Zemessardzes speciālisti neitralizē un iznīcina sprādzienbīstamus priekšmetus, sniedz atbalstu Valsts policijai un pašvaldībām civilās aizsardzības plānu (preventīvo, reageēšanas un seku likvidēšanas pasākumu) ìstenošanā, sabiedriskās kārtības un drošības garantēšanā, pazudušu personu meklēšanā, ugunsdzēsības un glābšanas darbos, dabas un tehnogēno katastrofu seku likvidēšanā, kā arī atbalsta Drošîbas policiju, Valsts robežsardzi, Valsts meža dienestu, Valsts vides dienestu un Dabas aizsardzības pārvaldi to uzdevumu izpildē. [4] Lai attīstītu Zemessardzes spējas pilnvērtīgāk sadarboties ar valsts un pašvaldības institūcijām, tiek pilnveidots tiesiskais regulējums un izstrādāts atbilstīgs sadarbības mehānisms, kas iekḷauj ne tikai vienošanos par sadarbības procedūrām un koordināciju, bet arī paredz organizēt speciālu apmācību. [5] 
Par nepieciešamību aktīvāk iesaistīt zemessargus policijas funkciju pildīšanā, kā arī par Zemessardzes darbinieku apmācības sabiedriskās kārtības un drošības nodrošināšanā lietderīgumu tiek diskutēts jau kādu laiku. Vairākkārt izskanējis viedoklis [16], ka varbūt veiksmīgāk būtu veidot sadarbību ar apsardzes komersantiem, nevis Zemessardzi. Kādēl būtu jāapmāca Aizsardzības ministrijas struktūrvienība? Vai, piemēram, tiek diskutēts par policijas palīga institūta nostiprināšanu un palīgu iesaistîšanu sabiedriskās kārtības nodrošināšanā. Autore gan norāda, ka jautājums ir par ārkārtas situācijām un krī̌zu pārvaldīšanu. Zemessardze ir Nacionālo bruṇoto spēku rezerve. Un, piemēram, masu nekārtību gadījumā, ja tiek pārsniegta policijas kapacitāte, ārkārtas situācijā tiek piesaistīti iepriekš apmācīti Zemessardzes spēki, kas ir valsts stratēéiskā rezerve un resursi. Šobrīd ir noslēgti sadarbības līgumi starp Zemessardzi un Valsts policiju, kā arī starp Zemessardzi un pašvaldībām. [10] Jānorāda, ka Zemessardze savas kompetences ietvaros ir un paliek valsts dienests. Ārkārtas gadījumos tā darbojas atbilstīgi savai kompetencei.

\section{Secinājumi}

Policijas kā valsts pārvaldes institūcijas viens no galvenajiem uzdevumiem ir nodrošināt sabiedrisko kārtību un drošîbu publisku pasākumu laikā. Lai arī šobrīd policijas iestādes skar virkne organizatorisko (personālsastāva) un tiesisko problēmu, policijas dienestu uzdevums ir veikt visefektīvākos pasākumus, lai garantētu pasākumu mierīgu norisi. Policijas dienestu rīcības efektivitāti publisku pasākuma laikā nosaka ne tikai spēja ātri reagèèt un novērst sabiedriskās kārtības pārkāpumus, bet arī likumiska un samērīga policijas rīcība pārtraucot sabiedriskās kārtības pārkāpumus. Pašvaldības policijas institūts (arī Zemessardze kā Nacionālo bruṇoto spēku sastāvdaḷa) ir viens no nozīmīgākajiem Valsts policijas sadarbības partneriem policijas funkciju nodrošināšanā. Tas nozīmē, ka paredzot konkrētus sadarbỉbas modeḷus, sadarbības līgumus starp valsts un pašvaldību institūcijām, kā arī tiesībaizsardzības institūcijām savā starpā, būtiski uzlabosies sabiedriskās kārtības nodrošināšanas kvalitāte publiskos pasākumos.

\section{State and Local Government Competence in Guaranteeing Public Safety during Public Events}

\section{Abstract}

Issues affecting the state and local government institution competence in public order and security maintaining in public events is becoming increasingly crucial. One of the most important tasks of the law enforcement agencies is guaranteeing public order and security. Although the crucial role in guaranteeing is devoted to local government 
bodies, where municipal police institute is currently one of the most important partners of the State Police in police powers provision, in practice are turning out a number of problems. First, whether the state and municipal police authorities have sufficient logistical and human resources to ensure public order in large-scale (and sensitive) public events. Second, whether the enforcement officers during public events use proportionate legal means to crack down violators of public order.

Keywords: public events, maintenance of public order and safety.

\section{Literatūra}

1. Latvijas Republikas Satversme. Latvijas Vēstnesis, Nr. 43, 1993. g. 1. jūl., 89. pants.

2. Likums "Par policiju": 1991. g. 4. jūn. Rīga: Ziņotājs, Nr. 37, 1992. g. 24. sept., 1. pants.

3. Publisku izklaides un svētku pasākumu drošības likums: 2005. g. 16. jūn. Latvijas Vēstnesis, Nr. 104 (3262), 2005. g. 6. jūl.

1. pants. Publisks pasākums - fiziskās vai juridiskās personas plānots un organizēts sabiedrībai pieejams svētku, piemiṇas, izklaides, sporta vai atpūtas pasākums publiskā vietā neatkarīgi no īpašuma piederības. Publiska vieta - jebkura vieta, kura neatkarīgi no tās faktiskās izmantošanas vai īpašuma formas kalpo sabiedrības kopējo vajadzību un interešu nodrošināšanai un kura par maksu vai bez maksas ir pieejama ikvienai fiziskajai personai, kas nav attiecīgās vietas īpašnieks, tiesiskais valdītājs, turētājs, algots darbinieks vai cita persona, kuras atrašanās attiecīgajā vietā ir saistīta ar darba pienākumu izpildi, pasākuma organizēšanu vai ir uz uzṇēmuma līguma pamata.

4. 2010. gada 9. oktobra Ministru kabineta noteikumi Nr. 936. "Kārtība, kādā Latvijas Republikas Zemessardze sniedz atbalstu valsts un pašvaldību institūcijām likumpārkāpumu novēršanā, sabiedriskās kārtības un drošības garantēšanā". Latvijas Vēstnesis, Nr. 160 (4352), 2010. g. 8. okt.

5. 2014. gada 7. aprīḷa Ministru kabineta rīkojums Nr. 151 "Par valdības rīcības plānu Deklarācijas par Laimdotas Straujumas vadītā Ministru kabineta iecerēto darbību īstenošanai”. Latvijas Vèstnesis, Nr. 71 (5131), 2014. g. 9. apr., 121. punkts.

6. 2005. gada 18. janvāra Ministru kabineta noteikumi Nr. 46 "Valsts policijas nolikums". Latvijas Vēstnesis, Nr. 12 (3170), 2005. g. 21. janv., 1. punkts.

7. 2010. gada 22. februāra Valsts policijas noteikumi Nr. 5 "Dienesta pienākumu izpildes darba organizācija un kontrole sabiedriskā kārtības nodrošināšanas un satiksmes uzraudzības jomā”, 2. un 4. punkts. Iegūts no: Valsts policijas iekšējā mājas lapā: http://intranet.vp.gov.lv

8. Latvijas Republikas Ekonomikas ministrijas 2014. gada jūnija ziṇojums par Latvijas tautsaimniecības attīstību. Rīga: LR Ekonomikas ministrija, 2014. ISSN 1407-4095.

Ziṇojumā norādīts, ka Latvijas ekonomika pēckrīzes periodā turpina sekmīgi attīstīties. 2012. gadā IKP pieauga par 5,2\%, bet 2013. gadā sasniedza pat 4,5\%. Preču un pakalpojumu eksporta apjomi ir sasnieguši vēsturiski augstāko līmeni, kopējam eksportam par gandrīz 20\% pārsniedzot pirmskrīzes perioda augstāko punktu. Arī turpmākā Latvijas ekonomikas izaugsme būs cieši saistīta ar eksporta iespējām un situāciju ārējos tirgos. Pakāpeniski stabilizējoties ekonomiskajai situācijai Eiropā, sagaidāms, ka turpmākajos gados Latvijas eksporta iespējas uzlabosies un ekonomikas izaugsme varētu sasniegt $4,5 \%$. 
Kristine Kuzṇecova. Valsts un pašvaldības kompetence sabiedriskās kārtības nodrošināšanā publiskos pasākumos

9. Valsts policijas Galvenās Kärtības policijas pärvaldes darba pārskats par 2014. gadu. Nepublicēts materiāls.

10. 2012. gada 26. janvārī noslēgtais sadarbības līgums starp Latvijas Republikas Zemessardzi un Daugavpils pilsētas pašvaldību par atbalstu sabiedriskās kārtības un drošības nodrošināšanā. Nepublicēts materiāls.

11. Kuzṇecova, K. Tiecoties īstenot efektīvu sabiedriskās kārtības nodrošināšanu - Latvijas un ārvalstu pieredze. Starptautiskās zinātniski praktiskās konferences rakstu krāj. Transformācijas process tiesībās, reǵionālajā ekonomikā un ekonomiskajā politikā. Rīga: BSA, 2013. 336 lpp.

12. Kviesītis, R. Kriminālpolicija kā servisa dienests noziedzības novēršanā un apkarošanā. Valsts policijas koledžas 3. starptautiskās zinātniskās konferences rakstu krājums. 2013, 155. lpp.

13. Lijphart, A. Democracy in Plural Society. A Comparative Exproration. Yale University Press, 1977.

14. Matvejevs, A. Normatīvie akti, kas reglamentē sabiedrisko kārtību sapulču, gājienu, piketu laikā. Administratīvā un kriminālā justìcija. [LPA], Nr. 4, 2007, 59. lpp.

15. Ozolz̄ile, G. Demokrātiskās stabilitātes priekšnosacījumi. Latvijas Policijas akadēmijas raksti, 5. [sēj.]. Rìga, 1998, 41. lpp.

16. Latvijas Iekšlietu darbinieku arodbiedrības viedoklis, sk.: IeM Sabiedriskās drošības konsultatīvās padomes sēdes protokols Nr. 15, 2011. g. 24. nov. Iegūts no: http://www.iem.gov.lv/files/ text/Protokols15.pdf

17. Pieredze vardarbības novēršanā. Demonstrācijas Amsterdamā. 2014. gada 13. novembra starptautiskās konferences Globālie, reǵionālie un nacionālie mehānismi spīdzināšanas un nežēlìgas vai pazemojošas izturēšanās novēršanai: dalāmies pieredzē izdales materiāli. Nepublicēts materiāls.

18. Policing Assemblies. Amnesty International Dutch Section. Police and Human Rights Program - Short paper series No. 1. 2013, p. 14. Iegūts no: https://www.amnesty.nl/sites/ default/files/ainl_phrp_short_paper_policing_assemblies.pdf

19. Ventspils pilsētas pašvaldības 2012. un 2013. gada publiskais pārskats. Iegūts no: http:// www.ventspils.lv/lat/ventspils_parvalde/publiskie_dokumenti/pasvaldibas_publiskais_parskats/ 20. Аейпхарт, А. Многосоставные общества и демократические режимы. Полис, 1992, 217 с. 


\title{
Policijas zinātnes attīstība Eiropā
}

\author{
Aleksandrs Matvejevs \\ Daugavpils Universitāte, Sociālo zinātṇu fakultāte, \\ Tiesību katedra, Latvija
}

\section{Kopsavilkums}

Policijas zinātnes attīstības perspektīvas Eiropā un ar to saistītie pētījumu rezultāti atspoguloti publicētajos materiālos. Pētījumos ir atspoguḷoti dažādi viedokḷi, tomēr vairākums aizstāv uzskatu, ka Eiropā jāattīsta policijas zinātne kā atsevišḳa zinātnes nozare.

Pētījuma nolūks ir aplūkot policijas zinātnes attīstības perspektīvas Eiropā, un šì publikācija varētu kalpot par sākumu zinātniskām debatēm par policijas zinātnes jautājumu.

Policijas zinātne nākotnē varētu būt integrācijas instruments gan nacionālā, gan starptautiskā līmenī. Tās attīstības perspektīvas Eiropā ir atkarīgas gan no akadēmisko, gan policijas aprindu aktivitātēm.

Atslēgvārdi: policija, policijas zinātne, policijas darbība.

\section{levads}

Pētījumi policijas tiesībās, kriminologiijā, kriminālistikā utt. ir prezentējuši virkni teorētisko un empīrisko apkopojumu. Veiktajos pētijumos tiek izmantota starpdisciplināra pieeja, un vēl joprojām nav attīstìta policijas zinātne.

Raksta ideja ir ieskicēt policijas zinātnes attīstības perspektīvas Eiropā un izvērst diskusiju par iespēju attīstīt policijas zinātni Latvijā.

Latvijā 2001. gadā ar Zinātnes padomes lēmumu policijas tiesības tika iekḷautas juridiskās zinātnes apakšnozares klasifikācijā. Policijas tiesības ir juridisko zinātṇu apakšnozare, kura teorētiski un empīriski pēta policiju kā institūciju, tās darbības tiesiskumu, organizāciju, uzdevumus un lomu sociālajā struktūrā, tās darba stilu, efektivitāti, kā arī izpausmes veidu un attieksmi pret sabiedrību. 


\section{Pētijuma mērḳis un uzdevumi}

Pētījuma mērḳis ir izpētìt policijas zinātnes attīstības perspektīvas Eiropā. Izvirzītais mērḳis tika sasniegts, realizējot šādus pētỉjuma uzdevumus: apskatot policijas zinātnes vēsturi, policijas zinātnes aktuālos jautājumus, analizējot policijas izglītības un apmācības problēmas Eiropā.

Pētījuma zinātniskā novitāte ir saistīta ar to, ka pētỉjumā mēǵināts izsekot policijas zinātnes attīstības perspektīvām Eiropā.

Apkopojot izpētìto, jāsecina, ka var izveidoties konflikts starp teoriju un praksi, ja netiks veikti teorētiskie un empīriskie pētỉjumi par policijas jomu, lai nodrošinātu efektīvu policijas darbību.

\section{Policijas zinātnes vēsturiskā attīstība}

Lai gan terminam "policijas zinātne" mūsdienu sociālajās zinātnēs nav vispārpieñemtas nozìmes un citi to apzīmē kā policijas peetỉjumus vai zinātniskos pètījumus saistībā ar policiju, tam tomēr ir senas tradīcijas.

18. gadsimta sākumā bija pirmais mēgeinājums zinātniski analizēt policijas darbības jomu, kurā ietilpa visa iekšējā valsts pārvalde, ieskaitot justīciju un finanses. Francijā, aizsteidzoties priekšā citām valstīm, sāka veidoties zinātne par policiju.

18. gadsimtā policijas zinātne bija valdības zinātne, l̦oti plašs jēdziens, kas ietvēra gandrīz visus valdības uzdevumus. Līdzīgi kā franču vārds police, tā arī vācu polizei apzīmēja veselu virkni valdības aktivitāšu ilgi pirms laika, kad izveidojās policijas spēki, kuru uzdevums bija tās îstenot - tas notika galvenokārt 19. gadsimtā. [3]

Policijas zinātne kḷuva par akadēmisku disciplīnu dažās Eiropas valstīs 19. gs., un tā tika iekḷauta universitāšu programmās. Pat tajās valstīs, kur nelietoja terminu "policijas zinātne", tika izveidotas līdzīgas universitātes disciplīnas, ko apzīmēja ar terminiem "politiskā zinātne" vai pat "militārās zinātnes".

20. gs. termins "policijas zinātne" sāka izzust, to aizstāja ar kriminologijas un kriminālistikas nozīmi.

Kopš pagājušā gadsimta 70. gadiem lielākajā daḷā Eiropas valstu parādās empīriskie pētījumi, kas notiek divējādi: pētījumus veic akadēmiskais personāls par policijas darbību un pētījumi, ko ierosina pati policija. Pētījumi Eiropā saistīti ar policijas un tās aktivitāšu vēsturisko pirmsākumu un attīstības izpēti. Lielākajā dạ̦ā Eiropas valstu policijas funkcijas pakāpeniski tiek atdalītas no militārā spēka lietošanas, un valdnieku privātās intereses tiek balstītas uz tiesību aktiem, lai nodrošinātu taisnīgumu un tiesu varu un kalpotu visas sabiedrības interesēm. Citi pētỉjumu temati, sekojot vēsturiskajai perspektīvai, ir saistīti ar policijas un politikas savstarpējo iedarbību, kā arī policijas funkciju un lomas dažādošanu.

Pētỉjumi var aptvert l̦oti plašu lomu spektru, ko policija ieņem kā noziegumu novērsēji, kā pakalpojumu sniedzēji, kā kārtības nodrošinātāji un nekārtību un domstarpỉbu novērsēji. 
Policijas aktivitāšu stratēgijas un stili ir kḷuvuši par svarīgu policijas pētijumu sastāvdaḷu. Kriminālizmeklēšanas process, policijas darbības modelis, kas pielāgots kopienu interesēm, ASV zinātnieka Hermaṇa Goldsteina (Herman Goldstein) uz problēmām orientētais policijas darba stils [9] un policijas darbỉba, balstìta uz slepeno informāciju - tie ir dažādie stili, kas zināmi un par ko tiek diskutēts daudzās Eiropas valstīs. Ielūkojoties policijas pētījumos, kas skar pašu policijas organizāciju, tad daudz tiek diskutēts par vadības problēmām un policijas darba kultūru.

\section{Policijas zinātnes jēdziena raksturojums}

Kas ir zinātne? Zinātne ir pētnieciskās darbības sfēra, kuras mērḳis ir jaunu zināšanu radīšana un sistēmiska sakārtošana. [8]

Vai policijas zinātne ir fundamentāla vai lietiškła? Policijas zinātne veic zinātniskus pētỉjumus par policiju kā institūciju un policijas darbību kā procesu. [6] Kā lietišḳa zinātne tā apvieno radniecīgas zinātniskās izziņas metodes un subjektus policijas aktivitāšu jomā, ieskaitot to, ko policija dara, kā arī ietekmi no ārpuses, kas atstāj iespaidu uz sabiedrisko kārtību un policijas darbību. Policijas zinātne ir pētnieciskās darbības sfēra, kuras mērkis ir jaunu zināšanu radīšana un sistēmiskā sakārtošana, kas attiecas uz policijas darbības realitāti. Policijas zinātne atrodas grūti risināmu jautājumu viduspunktā un skar pētỉjumu, apmācību, izglìtỉbas, pilnveides un inovāciju būtību. Tā nav zinātne pati ar saviem likumiem, tā apvieno radniecīgas zinātniskās izziṇas metodes, piemēram, sociālo zinātṇu, kriminolog̣ijas un kriminālistikas.

Kā lietišķa zinātne tā uzrunā policijas pētỉjumus veicošo akadēmisko pasauli, kā arī policijas darbiniekus, kas iesaistīti apmācībā, izglìtībā, pētniecībā un problēmu atrisināšanā, meklējot zinātnē balstītus risinājumus.

Pirmkārt, policijas zinātne tās plašā izpratnē un vispārējā nozīmē - kā dažādu zinātṇu nozaru izmantošanas iespēja, lai sekmētu policijai izvirzìto mērḳu sasniegšanu, piemēram, policijas tiesību, kriminālistikas, kriminolog̣ijas un citu zinātṇu nozaru izmantošanas iespēju pētǐšana.

Otrkārt, policijas zinātne tās šaurā nozīmē koncentrējas uz policiju kā institūciju un tās darbību sabiedrības kontroles jomā.

Var izdarìt secinājumu, ka dotajā policijas zinātnes jēdziena pirmajā nozīmē tiek runāts par dažādu zinātṇu nozaru pētijumu rezultātu izmantošanu policijā (profesionālismu un specializāciju). Otrā gadījumā policijas zinātne tiek orientēta uz policiju kā institūciju tās organizācijas un darbības attīstību uz zinātnes pamatiem.

Ar "policiju" mēs saprotam valsts institūciju (vai institūcijas), kas ar nelielām atš̌kirībām pazīstama visās Eiropas valstīs. [2] Pretēji tai "policijas darbība" ir process: termins, ko varam piemērot sabiedrības drošības un sabiedriskās kārtības nodrošināšanai [4], noziedzības novēršanai un atklāšanai, reageējot uz izsaukumiem un saistībā ar noziedzīgā nodarījumā cietušajiem. Bez policijas te var būt iesaistītas bezpel̦nas organizācijas, piemēram, nevalstiskas organizācijas vai arī pelnošas organizācijas privātā sektorā. Tātad te ir runa par policijas darbību jaukta tipa aktivitātēs, kurās piedalās arī citas 
organizācijas. Lai gan policijas darbības pasūtītājs ir valsts, tradicionālā Valsts policija tagad ir atbildīga tikai par dal̦ēju policijas pakalpojumu sniegšanu daudzās Eiropas valstīs. Pārējo nodrošina privātais sektors, citas valsts sektora institūcijas. To varētu nosaukt par policijas darbības mūsdienu "daudzpusību", un viens no policijas zinātnes būtiskākiem jautājumiem būtu izpētīt šìs paplašinātās policijas darbības izpratnes nozīmi.

Turpmākā pētījumu attīstība nevar aprobežoties ar policiju kā institūciju, zinātniskie pētỉjumi par drošību un policijas darbību paplašināsies, veidojot vispārīgāku izpētes līmeni.

\section{Eiropas pieeja policijas zinātnei}

Galvenais mērḳis Eiropas pieejā policijas zinātnei ir policijas institūciju, policijas filozofiju, darba procesu un viedokḷu par problēmām salīdzināšana. Salīdzināšanas nolūks policijas darbības jomā ir iegūt informāciju par līdzīgiem jautājumiem un problēmām ārzemēs, samērojot savus sasniegumus ar citu veikumu, panākt labāku izpratni citam par citu Eiropā, labāk saprast pašiem savas aktivitātes. [10]

Salīdzinošā pieeja (lai arī bieži tikai kā papildu aspekts) sakārto pieredzes un informācijas apmaiṇu sistemātiskā veidā, dodot iespēju mācīties citam no cita. Tas ir nopietns solis cẹ̦ā uz Eiropas identitāti, laujot zināt, kas notiek, kāpēc notiek un kādi bùtu alternatīvie celii, lai to paveiktu.

Policijas zinātne ir lietišḳā zinātne, un tā seko citu zinātṇu salīdzinošām perspektīvām un metodologiskajiem standartiem.

Metodologija ietver divas pieejas: skatoties no augšas uz leju - tā ir tuvāka sociālo zinātṇu metodologijai. Skatoties no reālas policijas darbības, tā rada metodes atbilstoši problēmām. Un pretēji: pirmās ir problēmas un pētnieciskā darba jautājumi un tad, kā otrais solis, tiks izvēlēta un attīstìta piemērota metodologiskā pieeja.

Mūsdienās policijas darbs nav autonoma, neatkarīga profesija. Tas lielā mērā ir atkarīgs no sabiedrības attīstības, politikas un noziedzīgajām struktūrām. Mainīgās noziedzīgās struktūras prasa izmaiṇas policijas darbībā un piemērotu instrumentu izvēlē - policijas darbā izmaiṇas ir jāuztver kā normāla parādība.

Sastopoties ar pašreizējām nacionālās un starptautiskās policijas pētniecības, izglìtības un apmācības aktivitātēm, var apgalvot, ka daudzas no tām ir atsevišḳas problēmas, ko nosaka praktiskās vajadzības, bet vispārīgie jautājumi policijas kultūrā tiek lielākā vai mazākā mērā atstāti bez ievērības. Varētu būt, ka tas ir saistìts ar zinātniski pētniecisko darba un apmācību kultūru, kuru nosaka praktiskā un empīriskā dominēšana un bailes no "teorijas".

Tiklīdz pētnieks kādā policijas institūcijā tiek turēts aizdomās, ka viṇš rada "teoriju" "praktisku zināšanu" vietā, viņš ātri vien tiek izslēgts no spēles. Bet policijas zinātnei ir nepieciešama "teorija" ne tikai piemērotu metodoloğisko aspektu dēl, bet arī diskusijām par galvenajiem jautājumiem.

Viens no svarīgākajiem uzdevumiem nākotnē ir aptvert galvenos aspektus policijas darbībā, novērojot, analizējot, aprakstot un dodot ieguldījumu specifiskās pētniecības un mācību aktivitātēs. 
Otrs aspekts ir turpināt apspriešanu un iekḷaut Eiropas policijas zinātnes attīstības vēsturi pētniecības darba un mācību aktivitātēs. Šis varētu būt arī Eiropas identitātes elements zinātniski pētniecisko un mācību aktivitāšu jomā.

Pievēršot uzmanību pārrobežu perspektīvai, jāsāk ar salīdzinošo aspektu. Eiropas valstīs trūka salīdzinošo pētījumu.

Nepieciešami salīdzinošie pētījumi par šādām jomām: policijas sistēmas, policijas filozofijas, policijas vēsture, policijas darba stili, policijas kultūra utt., un tas ir svarīgs uzdevums saistībā ar nākotnes perspektīvām.

Jāsecina, ka policijas zinātne vēl nav sasniegusi citu radniecīgu zinātṇu līmeni, piemēram, politolog̣ijas līmeni, kur politisko sistēmu salīdzināšanai ir ierādīta centrālā vieta.

Tā ir atslēga, lai izprastu un izskaidrotu, kas notiek Eiropā policijas darbības jomā. Citiem vārdiem sakot, par šìm jomām nav izpratnes bez salīdzinošas izpētes.

Valstu ietvaros policijas darbïbas koncepcijas un to pielietojumu praksē var apgūt, valstīm salīdzinot savas sistēmas un darba rezultātus. Darbības vērtējuma kritēriji ieviešami praksē Eiropas policijas darbības jomā. Līdz šim nav atrasta sistemātiska pieeja, kā to paveikt. Vēl vairāk, papildu ceḷi informācijas vākšanai būtu pārveidojami sistemātiskā pieejā, lai iegūtu un izplatītu zināšanas, kas balstās uz zinātniski pētnieciskā darba rezultātiem. Pat atsevišḳu problēmu jautājumu salīdzinošie pētỉjumi varētu būt solis pretī efektīva izvērtējuma izstrādei, pat ja netiktu lietots šis termins.

Papildu dimensija policijas zinātnē ir tā, kas vairāk sakṇojas politikā, nevis teorijā. Apskatot jautājumu, kā policijas darbība saplūst un apvienojas dažādās Eiropas valstīs, var apsvērt, cik lielā mērā attīstība vienā ir bijusi veiksmīgāka nekā citās. Te viens no aspektiem ir policijas darbības efektivitātes izvērtēšana. [5]

\section{Policijas izglīīiba un policijas apmācība}

Boloṇas procesam ir dziḷa ietekme uz universitāšu/augstāko mācību iestāžu sistēmu Eiropā. Eiropas Savienības dalībvalstīs policijas apmācības un izglìīibas sistēma mainās, virzoties pretī Boloṇas procesa rekomendāciju pien̦emšanai. [11]

Policijā domas dalās par attieksmi pret turpmākās policijas izglìīibas attīstības risinājumiem. [7]

Policijas apmācība ietver procesu, kurā iegūst zināšanas, apgūst prasmes un iemaṇas, lai varētu veikt specifiskus profesionālos uzdevumus.

Policijas izglīiības mērḳis arī ir zināšanas, prasmes un domāšanas veids, bet to māca, vairāk attīstot domāšanu, izpratni, tas ir vairāk vērsts uz problēmu risināšanu un analīzi.

Policijas zinātne piedāvā palīdzību gan policijas izglìtỉbai, gan policijas apmācībai. Saturs (policijas izglīīibas temati), metodologija (pētijumi un problēmu risināšanas metodes) un intelektuāla attīstība (kritiskā domāšana) ir sastāvdal̦as saiknei starp policijas izglïtību un policijas zinātni. Tas viss veicina un attīsta studentu spējas vispārināt, saskatìt attiecības un efektīvi darboties jaunās situācijās, ko pilnībā nevar vizualizēt vai definēt. 
Policijas apmācība vairāk balstās uz praktisko pieredzi un praktiskām iemaṇām, tomēr tā nebūtu jānoškị no policijas zinātnes.

Mūsdienu sabiedrībā, kas balstīta uz zināšanām, praktiskās iemaṇas un prasmes var pamatot uz zināšanām, kas iegūtas no zinātnes un pētỉjumu rezultātiem, lai gan tās mērḳis nav radìt zinātniskus cel̦us problēmu risināšanai.

Policijas apmācību un izglītības sistēmas Eiropas Savienības dalībvalstīs parāda nepieciešamību sadarboties praktiskā darba veicējiem ar akadēmisko personālu, policijas darbiniekiem - ar pētniekiem.

Policijas zinātnes rezultātu îstenošana policijas praksē ir liels nākotnes izaicinājums.

Daži uzskata, ka būtu jānoškirir policijas apmācība no policijas izglītības, sakot, ka policijas pētnieciskais darbs var brīvi attīstīties tikai tad, ja to veic zinātniski pētnieciskajos institūtos neatkarīgi no policijas. Citi aizstāv viedokli, ka jāintegrē policijas apmācība un izglītība, pārveidojot Eiropas Savienības nacionālās policijas akadēmijas par akreditētiem akadēmiskiem institūtiem augstskolu (universitāšu) sistēmā, tādā veidā padarot pozitīvo ietekmi, ko policijas pētījumi un augstākā izglīiība atstāj uz policijas organizāciju, iespējami lielāku.

Boloṇas process nodrošina šīs attīstības vispārīgo struktūru, kurā par akreditāciju ir atbildīgas nacionālas akreditācijas institūcijas.

Otra pieeja, kas ir sakritīga ar iepriekšminēto, ir izveidot Eiropas mēroga kopējas studiju programmas vadlīnijas policijas apmācībām un izglìtībai. [1]

\section{Development of Police Science in Europe}

\section{Abstract}

Development of police science in Europe and related research results are presented in the published materials. Studies have been published presenting different opinions, but the majority view is that Europe should develop a police science as a separate branch of science.

The study aims to look at the development of police science in Europe, which could serve as the beginning of scientific debate on this issue.

Police science might be an instrument of integration, both nationally and internationally in the future. The perspectives of its development in Europe are dependent on both the academic and community policing activities.

Keywords: police, police science, police activity. 


\section{Literatūra}

1. Garonskis, A. Eiropas policijas akadēmijas loma mūsdienu policijas darbinieku izglītošanā. Starptautiskās zinātniski praktiskās konferences "Policijas augstākās izglītības vadības problēmas" materiāli. LPA, 2007, 11.-20. lpp.

2. Indrikovs, Z. Policijas jēdziens demokrātiskā valstī. Administratìvā un Kriminālā Justīcija, Nr. 3, 2007, 13.-21. lpp.

3. Matvejevs, A. Policijas institūta un policijas tiesību zinātnes veidošanās sākumi. Administratīvā un Kriminālā Justīcija, Nr. 1, 2007, 25.-32. lpp.

4. Matvejevs, A. Sabiedriskās kārtības un sabiedrības drošības jēdzienu definējums un analīze. Administratìvā un Kriminālā Justīcija, Nr. 2, 2007, 35.-46. lpp.

5. Matvejevs, A. Valsts policijas darbības efektivitātes vērtēšanas tiesiskie kritēriji. Administratīvā un Kriminālā Justìcija, Nr. 3, 2005, 60.-66. lpp.

6. Matvejevs, A. Policijas zinātnes attīstības daži aspekti. Administratīvā un Kriminālā Justīcija, Nr. 2, 2004, 35.-38. lpp.

7. Smits, S., Emodts, M. Saistība starp izglītību, pieredzi un policijas darba izpildi. Administratīvā un Kriminālā Justìcija, Nr. 2, 1999, 50.-53. lpp.

8. Vedins, I. Zinātne un patiesība. Rìga: Avots, 2008, 15. lpp.

9. Goldstein, H. Improving policing: A problem-oriented approach. Crime E Delinqency, Nr. 25, 1979, p. 236-258.

10. Perspectives of police science in Europe. Final Report, European Police College, April, 2007, [sk. 2015. g. 26. janv.] Iegūts no: www.cepol.europa.eu/

11. Schindler, T. Die polizei auf dem weg nach Bologna. Journal, Zeitschrift Für Polizeiwissenhaft und Polizeiliche Praxis. Respublik Österreich, Nr. 2, 2007, p. 25-40. 


\title{
Tiesību vienpusēji atkāpties no līguma realizēšanas problemātika
}

\author{
Jänis Meija \\ Rīgas Stradiña universitāte, Juridiskā fakultāte, Latvija
}

\section{Kopsavilkums}

Raksta uzdevums ir sniegt ieskatu tiesību vienpusēji atkāpties no līguma realizēšanas problemātikā, kas pastāv, jo Latvijas civiltiesībās līgumu pildī̌anas (pacta sunt servanda) civiltiesību pamatprincipam ir visai maz izṇēmumu.

Rakstā izcelta problēmas praktiskā puse, kas saistās ar pārmērīgu zaudējumu, nevienlīdzīgām pušu attiecībām vai apstākḷ maiṇu. Rakstā analizēts pozitīvs piemērs patērētāju kreditēšanas normatīvais regulējums.

Problēmas novitāti apliecina līgumtiesību starptautiskās unifikācijas tendences, un par tām pieaug publikāciju skaits. Secinot, ka Civillikumā paplašināmas līdzēju tiesības vienpusēji atkāpties no līguma, autors piedāvā attiecīgu likumu grozījumu redakciju.

Atslēgvārdi: līguma saistošais spēks, pacta sunt servanda, tiesības vienpusēji atkāpties no līguma, vienpusēja atkāpšanās no līguma, būtisks līguma pārkāpums.

\section{Raksta mērḳis}

Raksta mērḳis ir, izmantojot analītisko pētījumu metodi un analizējot Latvijas Republikas normatīvo regulējumu un tā praktisko piemērošanu, sniegt ieskatu tiesību vienpusēji atkāpties no līguma realizēšanas problemātikā, kas pastāv, jo Latvijas civiltiesībās līgumu pildī̌anas (pacta sunt servanda) civiltiesību pamatprincipam ir visai maz izṇēmumu.

Izceḷot problēmas praktisko pusi, kas saistās ar pārmērīgu zaudējumu, nevienlīdzīgām pušu attiecībām vai apstākḷu maiṇu, kā pozitīvs piemērs rakstā analizēts patērētāju kreditēšanas normatīvais regulējums. Līgumtiesību starptautiskās unifikācijas tendences un par to pieaugošo publikāciju skaits apliecina problēmas šā briža aktualitāti. 
Jānis Meija. Tiesību vienpusēji atkāpties no līguma realizēšanas problemātika

\section{Rezultāti}

Pacta sunt servanda principam ir noteicoša loma Latvijas Republikas Civillikuma [4] normu piemērošanā. Šis princips izteikts Civillikuma [4] 1587. pantā, kas noteic, ka tiesīgi noslēgts līgums uzliek līdzējam pienākumu izpildìt apsolìto, un ne darỉjuma sevišķais smagums, ne arī vēlāk radušās izpildīšanas grūtības nedod vienai pusei tiesību atkāpties no līguma, kaut arī atlīdzinot otrai zaudējumus. Civillikuma [4] 1588. pants pastiprina minēto līdzēja pienākumu, paredzot, ka viena puse nevar atkāpties no līguma bez otras piekrišanas pat tad, ja pēdējā to neizpilda, un tādẹl, ka viña to neizpilda.

Praksē jāsaskaras ar minētā principa realizēšanas problēmām, piemēram, ja otra puse nepilda līguma noteikumus, ir ierobežotas tiesības vienpusēji atkāpties no līguma, kā arī ir apgrūtināta iespēja slēgt citu līgumu par nesaṇemto līguma priekšmetu.

Tāpat Civillikuma [4] 1587. un 1588. panta regulējums ir uzskatāms par netaisnīgu līgumos ar nesamērīgām pušu saistībām un dažos līgumos ar juridiskajām personām, kurām pēc līguma noslēgšanas pasludināts maksātnespējas process.

Tiesības vienpusēji atkāpties no līguma kā pacta sunt servanda principa izṇēmums: pacta sunt servanda principa mērḳis ir civiltiesiskās stabilitātes nodrošināšana, tomēr šo mērḳi nepieciešams sabalansēt ar taisnīguma principu civiltiesiskajās attiecībās, ja būtiski mainījušies apstākḷi, kas ietekmē saistību pildīšanas pienākumu. Slēdzot darījumus, kuros nodibinātās saistības izpildāmas ilgtermiñā, līdzējiem ir iespēja pielīgt saistību izbeigšanas iespēju, piel̦aujot situāciju, kurā sevišḳi izmainās apstākḷi. Puses, slēdzot līgumu, ṇem vērā līguma noslēgšanas brīdī pastāvošos apstākḷus. Tādēl tiesības vienpusēji atkāpties pieḷaujams pamatot vienīgi ar apstākḷiem, kas var iestāties nākotnē.

Latvijas Republikas normatīvajos aktos noteiktās tiesības vienpusēji atkāpties no līguma izpildes un priekšlikumi normatīvā regulējuma uzlabošanai:

Civillikuma [4] 1589. pantā noteikts, ka vienpusēja atkāpšanās no līguma ir piel̦aujama tikai tad, kad tā pamatota ar paša līguma raksturu vai kad to zināmos apstākḷos atḷauj likums, vai arī kad tāda tiesība bijusi noteikti pielīgta.

Civillikums [4] paredz tiesības vienpusēji atkāpties no līguma:

1) sakarā ar darījuma formas neievērošanu (CL 1475. panta otrā daḷa, 1488. panta 3. punkts, 1489. pants);

2) pārmērīga zaudējuma gadījumā nomas un īres tiesiskajās attiecībās (CL 2170. pants);

3) pārāk zema aprēḳina un plāna sagrozī̌sanas gadījumā uzṇēmuma līguma tiesiskajās attiecībās (CL 2229. pants).

Arī citi normatīvie akti regulē tiesības vienpusēji atkāpties no līguma, piemēram, Publisko iepirkumu likuma [7] 67. panta otrās dal̦as 7. punkts paredz, ka iepirkuma līgumā norādāma kārtība, kādā pieḷaujama atkāpšanās no līguma, Patērētāju tiesību aizsardzības likuma [6] 12. panta pirmajā dạ̦ā noteiktās atteikuma tiesības paredz patērētāja tiesības noteiktā termiṇā vienpusēji atkāpties no līguma, Komerclikuma [5] 478. panta otrā daḷa nosaka līdzēju tiesības vienpusēji atkāpties no franšīzes līguma, ja saistību izpilde kḷuvusi pārmērīgi apgrūtinoša objektīvu apstākḷ izmaiṇu dẹḷ. 
Vienpusējas atkāpšanās tiesības no līguma nodalāmas no vienpusēja prasījuma tiesībām tiesas ceḷā prasīt līguma atcelšanu, kas paredzētas, piemēram, Civillikuma [4] 1663. pantā, ja kreditors parādnieka nokavējuma dēl vairs nav ieinteresēts līguma izpildī̌̌anā, tad viṇš var prasît tā atcelšanu.

Civillikuma [4] 2040. pantā paredzētas tiesības izṇēmuma veidā pēc vienas puses prasijuma atcelt pirkuma līgumu, ja viena puse bijusi piedabūta noslēgt līgumu vai nu ar otras l̦aunprātību, vai ar viltu, vai ar spaidiem, pirktās lietas trūkumu dēl, pamatojoties uz blakus nolīgumiem, ar kuriem paturēta atkāpšanās tiesība, un pārmērīgā zaudējuma dēl, ko cieš viena vai otra puse.

Latvijas likumos nav tāda jēdziena "būtisks līguma pārkāpums", taču UNIDROIT Starptautisko komerclīgumu principi, ANO Konvencija par starptautiskajiem preču pirkuma līgumiem un Eiropas līgumu tiesību principi atzīst sarežgijijumu izpausmes, kas tomēr parasti neved uzreiz pie tiesībām atkāpties no līguma.

Atšk রirībā no Latvijas Civillikuma norādītajos aktos ietvertas divas citas risinājumu iespējas:

1) pagarinājuma noteikšana saistības izpildei;

2) sarunas par līguma pārveidošanu, grozišanu $[2,38]$.

Eiropas zinātnieki izstrādā vispārinātus noteikumus, generālklauzulas par līgumu izpildē radušos sarežğijumu atrisināšanu [3, 68].

Tādēḷ, secinot, ka Civillikumā paplašināmas līdzēju tiesības vienpusēji atkāpties no līguma, attiecībā uz aplūkoto problemātiku Latvijas tiesību sistēmā apsverama iespēja Civillikuma 1588. pantu izteikt šādā redakcijā: "Viena puse nevar atkāpties no līguma bez otras piekrišanas pat arī tad, ja pēdējā to neizpilda, izṇemot gadijjumus, ja pēdējā, neizpildot līgumu, būtiski pārkāpj tā noteikumus."

Iepriekšminētā kontekstā raksta turpinājumā tiks analizēts patērētāju kreditēšanas normatīvais regulējums, kas ir pozitīvs piemērs minētās problēmas speciālam regulējumam.

Ministru kabineta 2010. gada 28. decembra noteikumu Nr. 1219 "Noteikumi par patērētāja kreditēšanu" [8] 27. punktā norādīts, ka patērētājam pirms kreditēšanas līguma saistību uzṇemšanās jābūt informētam par sekām, ja netiks veikts maksājums.

Tādējādi, ietverot kreditēšanas līgumā tiesības vienpusēji atkāpties no līguma, pirmkārt, līgumā būtu jānorāda, konkrēti par kādu līguma punkta pārkāpumu piemērojamas tiesības vienpusēji atkāpties no līguma. Otrkārt, patērētājam jāizprot, vai katrā no uzskaitïtajiem gadījumiem, kad līgumā ir paredzētas kredītiestādes tiesības vienpusēji atkāpties no līguma, līgumsaistību izpilde tiek būtiski ietekmēta. Treškārt, patērētāju tiesību aizsardzības kontekstā, piemērojot Patērētāju tiesību aizsardzības likuma [6] 5. pantā noteikto līgumslēdzēju pušu tiesiskās vienlīdzības principu, jāizvērtē, vai kreditors prettiesiski sev par labu nav pielīdzis pārāk plašas un/vai nepamatotas tiesības vienpusēji atkāpties no patērētāju kredītlīguma.

Patērētāju tiesību aizsardzības likuma [6] 6. panta pirmā daḷa nosaka: šādas kreditora pārāk plašas un / vai nepamatotas tiesības vienpusēji atkāpties no patērētāju kredìtlīguma var tikt atzìtas par netaisnīgu līguma noteikumu. 
Lai panāktu, ka patērētāju kredītlīgumā ietvertās prasības kreditora tiesībām vienpusēji atkāpties no patērētāju kredītlīguma ir skaidras un abu līgumslēdzējpušu interesēm atbilstošas, nepieciešams ievērot šādus nosacijumus:

1) tiesībām vienpusēji atkāpties no patērētāja kreditēšanas līguma jābūt konkrēti atrunātām līgumā, atsaucoties uz konkrētiem līguma pārkāpumiem, kas var izsaukt attiecīgu kreditora rīcību;

2) līguma pārkāpumiem jābūt precīzi noteiktiem, tie nedrīkst būt pārlieku plaši piemērojami, lietojot tādus formulējumus kā "jebkuri līguma pārkāpumi” vai "jebkura līguma noteikuma neizpilde".

Ja minētais nav ievērots, tad šādi līgumā ietverti formulējumi ir prettiesiski un nevar būt par pamatu vienpusēji atkāpties no kreditēšanas līguma.

Turklāt jāṇem vērā, ka patērētāju kreditēšanas līgumā jānorobežo nozīmīgi līguma pārkāpumi no maznozīmīgiem. Maznozīmīgi līguma pārkāpumi pēc būtības vispār neiespaido līgumā uzṇemto saistību izpildi. Tādēl, pielīgstot kreditoram tiesības vienpusēji atkāpties no līguma, atsaucoties uz to, ka patēēēājs, saskañā ar līguma noteikumiem, piemēram, nav paziņojis par savas deklarētās dzìvesvietas maiṇu 10 dienu laikā no dzīvesvietas maiṇas brīža, patērētājs tiek nostādìts neizdevīgā stāvoklī attiecībā pret pakalpojuma sniedzēju saskaņā ar Patērētāju tiesību aizsardzības likuma [6] 5. panta otrās daḷas 5. punktu un 6. panta trešās daḷas 1. punktu, un šāds noteikums būtu uzskatāms par netaisnīgu līguma noteikumu.

Savukārt pie būtiskiem pārkāpumiem, kas var ietekmēt nozīmīgas kreditora intereses un var būt par pamatu kreditora tiesībām vienpusēji atkāpties no kreditēšanas līguma, pieskaitāma, piemēram, kredīta atmaksas vai procentu samaksas maksājumu kavēšana līguma saistību izpildi ietekmējošu laika posmu.

Kreditora tiesībām vienpusēji atkāpties no līguma jābūt samērīgām ar patērētāja pieḷauto līguma pārkāpumu. Nav pieḷaujams, ka patēētāja kreditēšanas līgumā tiek pielīgta kreditora tiesība vienpusēji atkāpties no šì līguma, ja, piemēram, savas saistības pret kreditoru nepilda galvotājs, kas galvojis par patēētāja saistībām.

Lìgumā ir jābūt noteiktam, ka pirms kreditors realizē savas līgumā pielīgtās tiesības par vienpusēju atkāpšanos no patēētāja kreditēšanas līguma, viṇam par to jābrīdina patērētājs noteiktā kārtībā un saprātīgā termiņā.

Uzskaitot līguma noteikumos gadijumus, kādos kreditoram ir tiesības vienpusēji atkāpties no līguma, būtu jāṇem vērā fakts, vai patērētājam uzliktais pienākums neierobežo patērētāja likumīgās tiesības. Tāpēc pirms patērētāja kreditēšanas līguma vienpusējas uzteikšanas, kreditoram būtu ieteicams izmantot citus, mazāk patērētāju ietekmējošus līdzekḷus patērētāja pieḷautā līguma pārkāpuma novēršanai.

Bez patērētāju kreditēšanas normatīvā regulējuma attīstǐšanas, likumdevējam būtu jāturpina Civillikuma modernizācija, kurā likumdevējam jāṇem vērā līgumtiesību tiesību unifikācijas dokumenti - priekšlikums regulai "Par vienotiem Eiropas tirdzniecības noteikumiem" (CESL), kopējā model̦a projekts (Draft Common Frame of Reference (DCFR)) un citu starptautisko tiesību unifikācijas dokumenti [1]. Tomēr šīm 
izmain̄ām un to piemērošanai Latvijas Republikas tiesu praksē jābūt pārdomātai un iepriekš pietiekami publiski apspriestai, jo pirmskara Latvijas Republikas likumdevēja iedibinātai civiltiesisko attiecību stabilitātei ir neatsverama nozīme Civillikuma normu piemērošanā.

\section{Enforcement Problems of the Right to withdraw from a Contract Unilaterally}

\section{Abstract}

The aim of the article is to provide an insight into problems of the right to withdraw from a contract unilaterally that exist because the Civil Law of Latvia has very few exceptions to the basic principle of contract filling (pacta sunt servanda).

The article highlights the practical side of the problem due to excessive loss, unequal relationship between the parties or a change of circumstances. Legal regulation of consumer creditation is analyzed in the article as a positive example.

The international unification trends of the Contract Law and the growing number of publications confirm the novelty of the problem. Concluding that the rights of parties to withdraw from a contract unilaterally should be extended in the Civil Code, the author proposes amendments to the relevant version of the laws.

Keywords: change of circumstances, pacta sunt servanda, right to withdraw from a contract unilaterally.

\section{Literatūra}

1. Torgāns, K. Saistību tiesības. I daḷa. Mācību grāmata. Rīga: Tiesu namu aǵentūra, 2006, 68. lpp.

2. Kalniṇa, V. Tiesības vienpusēji atkāpties no pirkuma līguma un to attīstīšana Civillikumā. Jurista Vārds, Nr. 40 (842), 2014. g. 14. okt.

3. Torgāns, K. Civillikuma Saistību tiesību daḷas modernizācijas nepieciešamība un aktuālo privāttiesiskā regulējuma tendenču (UNIDROIT, ELTP) iespējamā ietekme uz Civillikuma Saistību tiesību daḷas modernizāciju. Zinātnisks pētījums. Rīga: Zvērinātu advokātu birojs "Lejiňš, Torgāns un Partneri", 2007, 38. lpp.

4. Civillikums. [1937. g. 28. janv.] Valdības Vēstnesis, Nr. 41, 1937. g. 20. febr.

5. Komerclikums. [2000. g. 13. apr.] Latvijas Vēstnesis, Nr. 185/160 (2069/2071).

6. Patērētāju tiesību aizsardzības likums. [1999. g. 18. marts.] Latvijas Vēstnesis, Nr. 104/15 (1564/1565).

7. Publisko iepirkumu likums. [2006. g. 6. apr.] Latvijas Vēstnesis, Nr. 65 (3433).

8. Ministru kabineta 2010. gada 28. decembra noteikumi Nr. 1219 "Noteikumi par patērētāja kreditēšanu". Latvijas Vēstnesis, Nr. 2 (4400). 


\title{
Līgums par bērna izglītošanu izglītības iestādē un disciplīnas pārkāpumu novēršana
}

\author{
Ivans Jānis Mihailovs \\ Rìgas Stradiña universitäte, \\ Komunikācijas fakultāte, Latvija
}

\section{Kopsavilkums}

Viena no nopietnākajām izglītības problēmām mūsdienu Latvijā ir dažu izglītojamo nihilistiskā uzvedība, ignorējot atzītās uzvedỉbas normas un apdraudot citu personu psihoemocionālo labklājỉbu, veselību, drošību un dzīvību. Ir pietiekami grūti samērot vairākuma (piemēram, klases) un mazākuma (t. s. problēmbērna) intereses, īpaši ja viens izglītojamais apdraud vai traucē mācību procesu visai klasei.

Rakstā ir analizēti normatīvo aktu grozijumi, kas ir vērsti uz agresīvas uzvedības pārtraukšanu, vienlaikus paredzot noteikt atbalstu izglìtojamajam - pārkāpējam. Tomēr ieviestais jauninājums tiesiskajā regulējumā rada virkni problēmu, t. i., šobrīd ir aț̣auts individuāli strādāt ar agresīvu izglìtojamo, paredzot iespēju noteikt papildu atbalsta pasākumus, kā arī iesaistìt problēmas risināšanā pašvaldību. Tomēr joprojām galvenā problēma, lai veiksmīgi izmantotu normatīvajos aktos noteiktos instrumentus, ir finanšu un kompetento personālresursu trūkums, kā arī nepietiekamas izglītības iestāžu darbinieku juridiskās un pedagoğiskās zināšanas. Tāpēc mēǵinājumi ierobežot konkrēta izglìtojamā agresīvu uzvedību var novest pie jauniem pārkāpumiem vai problēmām.

Viena no iespējām, kura līdz šim nav pietiekami izmantota, lai mazinātu disciplīnas pārkāpumus vispārējās izglìiības un profesionālās izglìtỉbas iestādēs, ir līgums par bērnu izglìtošanu izglìīibas iestādē.

Atslēgvārdi: disciplīna, līgums par bērna izglītošanu izglītības iestādē, disciplīnas pārkāpumu novēršana, izglìtojamie, problēmbērni.

\section{levads}

Viena no nozīmīgākajām problēmām vispārējās izglìtības un profesionālās izglītības iestādēs ir izglītības iestādes iekšējās kārtības noteikumu ievērošana un izglìtojamā pienākumu apzinīga un godprātīga pildīšana. Šobrīd gandrīz katra izglīīibas iestāde ir 
"spiesta" izlietot ievērojamus resursus, lai cīnītos ar t. s. disciplīnas pārkāpumiem, piemēram, mācību stundu/nodarbību neapmeklēšanu bez attaisnojoša iemesla (bastošanu), mājas darbu nepildī̌̌anu, smēḳēšanu un alkoholisko dzērienu lietošanu izglìîibas iestādē, pedagogu un citu izglìtības iestāžu darbinieku prasību ignorēšanu u. c., dažiem izglītojamajiem (dažādu veselības, audzināšanas, sociālo, psihologiisko u. c. problēmu dẹl) atklāti ignorējot vispāratzītās uzvedības normas, ar savu nihilistisko un būtībā prettiesisko uzvedību apdraudot citu personu veselību, psihoemocionālo labklājỉbu, drošỉbu, dziviỉbu, traucējot mācību un audzināšanas procesu.

Turklāt bieži vien disciplīnas problēmas parādās jau pirmsskolā vai sākumskolā, tostarp pašam pārkāpējam pietiekami labi apzinoties, ka sava vecuma dēḷ viņš faktiski paliks nesodīts (piemēram, ignorējot mutiskos aizrādỉjumus, kā arī no noteikta vecuma apzinoties, ka no izglìtibas iestādes līdz pamatizglìtỉbas ieguvei vai 18 gadu sasniegšanai faktiski nav iespējams izglītojamo atskaitīt, savukārt audzinoša rakstura piespiedu līdzekḷu piemērošana ir pietiekami komplicēta, laikietilpīga procedūra (Likums "Par audzinoša rakstura piespiedu līdzekḷu piemērošanu bērniem"). Arī vecāki šajās problēmsituācijās vai nu nostājās pārkāpēja pusē (faktiski aizstāvot savu bērnu), vai dažādu sociālo, finanšu vai veselības problēmu dēl pietiekami maz interesējas par savu bērnu, vai arī uzskata, ka izglìtības iestādei ir jārisina tās problēmas, kuras nespēj atrisināt paši vecāki ğimenē.

Izglītības likuma 1. panta 4. punktā ir noteikts, ka izglītỉba ir sistematizētu zināšanu un prasmju apguves un attieksmju veidošanas process un tā rezultāts. Izglïtības process ietver mācību un audzināšanas darbību. Izglītỉbas rezultāts ir personas zināšanu, prasmju un attieksmju kopums (Izglīîibas likums). Tādējādi audzināšanas darbs, uzvedības noteikumu izveide un ievērošana, kā arī disciplīnas nodrošināšana, disciplīnas pārkāpumu un to iespējamības novēršana izglìtības iestādē, ir neatṇemams mūsdienu izglīîibas komponents.

Šajā kontekstā ir jāatzīmē 2013. gada augusta beigās publicētā "DNB Latvijas barometra" pētijuma rezultāti, kas liecina, ka lielākā dalı aptaujāto par vissteidzamāk risināmo problēmu Latvijas vispārējās izglītîbas un profesionālās izglītības iestādēs uzskata disciplīnas trūkumu izglītojamo vidū ("DNB Latvijas barometrs" Nr. 61, Izglitiba).

Jāatzīmē, ka šis raksts turpina autora iesākto pētījumu par vispārējās izglītības un profesionālās izglīiîbas iestāžu izglìtojamo drošības, disciplīnas un kavējumu novēršanas problēmām (Mihailovs, 2012; Mihailovs, 2014).

Raksta mērḳis - analizēt disciplīnas pārkāpumu novēršanas tiesiskā regulējuma aktuālos aspektus vispārējās izglìtības un profesionālās izglìtîbas iestādēs, kā arī analizēt iespējas izmantot līgumu par bērna izglītošanu izglìtības iestādē kā vienu no audzināšanas līdzekḷiem.

Materiāls un metodes - normatīvo aktu un to projektu analīze, izglìtības vadỉbas prakses analīze. 


\section{Rezultāti}

Audzināšanas jautājumu aktualizācija vispārējās izglītības un profesionālās izglīîibas iestādēs ir notikusi aptuveni pirms pieciem gadiem (līdz tam audzināšana bija it kā palikusi izglìīibas iestāžu darbības "novārtā" (Špona, Čamane, 2009), tostarp izglïtojamo un izglìtibas iestāžu darbinieku drošîbas garantiju kontekstā).

Izglìtības un zinātnes ministrija, reageèjot uz vairākiem sabiedrības uzmanību piesaistījušiem notikumiem (pārsvarā vardarbības izpausmēm izglìtības iestādēs), 2012. gada vasarā izstrādāja Ministru kabineta noteikumu projektu "Grozījumi Ministru kabineta 2009. gada 24. novembra noteikumos Nr. 1338 "Kārtība, kādā nodrošināma izglītojamo drošỉba izglītības iestādēs un to organizētajos pasākumos"', paredzot, ka, pamatojoties uz pedagoǵiskās padomes ieteikumu, izglītibas iestādes direktors agresīviem bērniem, kuri apdraud citu personu veselỉbu un drošību, var noteikt aizliegumu uz laiku (līdz vienam mēnesim) apmeklēt izglītỉbas iestādi, t. i., noteikt pamatizglītības programmā paredzētā satura apguvi ǵimenē. Ja mēneša laikā nebūs iespējams atrisināt problēmsituāciju, izglītỉbas iestādes direktors var pagarināt aizliegumu par diviem mēnešiem.

Lai gan šis noteikumu projekts ir izraisījis samērā plašas speciālistu un sabiedrības diskusijas, vērtējot to dažādi, kā liecina pētījumi, "vairāk nekā puse jeb 56\% Latvijas ekonomiski aktīvo iedzīvotāju vecumā no 18 līdz 55 gadiem atbalsta ieceri apmācìt agresīvos skolēnus mājās" (aptauja: lielākā daḷa iedzīvotāju atbalsta ieceri agresīvos skolēnus apmācìt mājās), faktiski redzot to kā vienīgo risinājumu citu izglìtojamo drošỉbas garantēšanai.

Tomēr šāda regulējuma ieviešana varēja radīt vairākas būtiskas problēmas:

1. Lai gan mācības bija paredzēts organizēt gimenē, nodrošinot pedagogu konsultācijas, šajā situācijā bērnam faktiski bija liegta pamatizglìtības ieguve pilnā apjomā (kas negatīvi varēja ietekmēt turpmāko mācību procesu), kā arī varēja tikt traucēta bērna adaptācija un socializācija klasē / izglìtības iestādē. Vienlaikus nebija skaidrs, kā šajā gadījumā tiks nodrošināta atbilstošo speciālistu, piemēram, sociālā pedagoga, psihologa, logopēda, ārsta, mērḳtiecīga un regulāra palīdzība? Ko darìt, ja bērns ir ar speciālām vajadzībām un agresīvu uzvedību izraisa veselības traucējumi? Jāṇem vērā, ka daḷa t. s. problēmbērnu, kuri neievēro uzvedības noteikumus izglītības iestādē, pietiekami labi mācās, "ar prieku iet skolā".

2. Ir diskutabli, vai atrašanās gimenē, mājās, kur ir atšksirīgs dienas režīms un disciplīnas prasības, veicinās izglītības iestādes iekšējās kārtības ievērošanu, laus sekmīgāk risināt komunikācijas problēmas ar citiem bērniem un pieaugušajiem, kā arī neveicinās vēl lielāku problēmbērnu atstumtību. Turklāt jāṇem vērā, ka bieži vien t. s. problēmbērni nāk no problemātiskām ğimenēm.

3. Nebija skaidrs, kā tiks nodrošināta pienācīga bērna uzraudzība, ja vecāks / vecāki, kuri nav audzināšanas speciālisti, strādā, dzīvo ārzemēs, vai arī, ja vecāki nespēj tikt galā ar bērnu, bērnam klaji ignorējot savu vecāku viedokli, vērtību sistēmu utt. 
4. Nebija skaidrs, kā tiks nodrošināta bērna reintegrācija izglìtības iestādē, klasē, grupā, pēc šì "attaisnotā" kavējuma. Vai skolēna prombūtne sekmēs bērna disciplīnu, mainīs viṇa uzskatus un vērtību sistēmu? Vai izglìtības programmas apguve gimenē netiks uztverta par izglïtîbas iestādes kolektīva bezspēcības atzī̌anu?

5. Aizliegums uz laiku (līdz vienam mēnesim) apmeklēt izglītības iestādi, t. i., izglìtības iestādes direktora lēmums noteikt pamatizglìīibas programmā paredzētā satura apguvi gimenē, ir satura izvēles administratīvais akts. Lìdz ar to aktualizējas jautājums par izglìtības iestādes administrācijas juridiskajām zināšanām, lai spētu kvalitatīvi sagatavot un atbilstoši pamatot šādu administratīvo aktu. Turklāt, ja šis administratīvais akts tiktu apstrīdēts, problēmas risināšana kavētos.

N̦emot vērā vairākus argumentus, kuri tostarp ir minēti šajā rakstā, izstrādātā Ministru kabineta noteikumu projekta virzība tika apturēta. Tādējādi šobrīd Latvijā nepastāv iespējas (pretēji vairāku valstu - Kanādas, Lielbritānijas, Vācijas, Somijas noteiktajam) kaut uz laiku aizliegt agresīvajam izglītojamajam apmeklēt izglīīibas iestādi.

2013. gada pavasarī tika izstrādāts jauns Ministru kabineta noteikumu projekts "Grozijumi Ministru kabineta 2009. gada 24. novembra noteikumos Nr. 1338 "Kārtība, kādā nodrošināma izglītojamo drošība izglīiības iestādēs un to organizētajos pasākumos"' (pien,emti 2013. gada 21. maijā), kurā tika noteikts: ja pedagogs konstatē, ka izglìtojamais rada apdraudējumu citiem, vin̄š par to informē izglìtỉbas iestādes direktoru, kurš, ja nepieciešams, nodrošina, ka izglìtojamajam tiek mainīta mācību vieta, t. i., viṇam tiek nodrošināta cita telpa, kurā viṇu pieskata izglītības iestādes atbalsta personāls vai kāds cits pedagogs (mācības citā telpā tiek nodrošinātas vienu mācību stundu vai pilnu mācību dienu). Par radušos situāciju izglītības iestādes direktors informē izglītojamā vecākus, tostarp norādot par nepieciešamību sadarboties ar izglìtības iestādi.

Ievērojot situācijas nopietnību, izglītības iestādes direktors nosaka atbalsta personāla pienākumus, lai veicinātu turpmāko sadarbību ar izglìtojamo un viṇa vecākiem, izstrādātu atbalsta pasākumus atbilstīgi izglìtojamā vajadzībām un situācijai, tostarp pēc vajadzības pieaicinot nepieciešamos speciālistus, un sadarbojoties ar izglītības iestādes dibinātāju - pašvaldību (Ministru kabineta 2009. gada 24. novembra noteikumi Nr. 1338 "Kārtība, kādā nodrošināma izglītojamo drošỉba izglìtỉbas iestādēs un to organizētajos pasākumos"; Ministru kabineta noteikumu projekta "Grozijumi Ministru kabineta 2009. gada 24. novembra noteikumos Nr. 1338 "Kārtība, kādā nodrošināma izglìtojamo drošība izglìîibas iestādēs un to organizētajos pasākumos"” sākotnējās ietekmes novērtējuma ziṇojums (anotācija)).

Tomēr arī šis risinājums izglītibas iestāžu vadības praksē rada vairākas problēmas, piemēram, ko darīt, ja agresīvais izglītojamais atsakās pakḷauties pedagoga vai izglīīibas iestādes direktora norādījumam un mainīt mācību telpu (vai šajā gadījumā mācību telpa 
ir jāmaina visai klasei), ko darīt, ja izglîtības iestādē nav atbalsta personāla un no tiešo pienākumu pildīšanas brīvo pedagogu, kuri varētu strādāt ar "izolēto" izglìtojamo, cik bieži šādā veidā izglītojamo var izolēt (jo izglītības iestāžu darbības praksē ir gadījumi, kad izglìtojamajam vairāku mēnešu laikā katru dienu tiek mainīta mācību vieta), kādi dokumenti ir nepieciešami, lai fiksētu šādu situāciju (pedagoga ziṇojums par izglìtojamo pārkāpumiem, izglītības iestāžu direktora rīkojums par mācību vietas maiṇu un atbildīgo darbinieku pienākumiem, strādājot ar šo izglìtojamo, sarakste ar vecākiem un pašvaldību, individuālais mācību plāns vai atbalsta pasākumu plāns, citi dokumenti)? Vai šajā gadỉjumā izglīīibas iestādei ir pietiekama kapacitāte, lai risinātu šīs problēmas? Vai izglïīibas iestāde atbalsta pasākumu īstenošanas gaitā ir tiesīga noteikt izglītojamajam pienākumu apmeklēt / konsultēties pie speciālistiem, kas nestrādā šajā izglìtības iestādē, bet, piemēram, strādā pašvaldībā vai citā iestādē, ar kuru ir noslēgts sadarbỉbas līgums? (Metodiskie ieteikumi darbā ar skolēniem, kuriem ir agresīvā uzvedība, 2012.)

Ir pietiekami grūti samērot vairākuma (piemēram, klases) un mazākuma (problēmbērna) intereses, ìpaši ja viens bērns fiziski apdraud apkārtējos un traucē mācību procesu visai klasei/izglītibas iestādei. Tomēr, kā jau ir norādīts, piedāvājot ieviest šāda problēmbērna atbalsta pasākumu kopumu, pēc būtības palika nerisinātas vairākas citas problēmas.

Jāatzīmē, ka jau 2008. gadā autors ir izteicis priekšlikumu izstrādāt izglìtības iestāžu kavētājiem un izglītojamajiem, kuriem ir būtiskas uzvedības un audzināšanas problēmas, īpašu sociālās audzināšanas / korekcijas programmu (nosaukums ir diskutējams), kuru varētu îstenot dažas izglìtības iestādes (piemēram, viena lielajā pašvaldỉbā vai pašvaldību grupā), piedāvājot šìm personām palīdzību (t. sk. nepieciešamo speciālistu atbalstu) un izglìtības ieguves iespējas. Turklāt izglìtojamo varētu pārcelt šajā programmā bez vecāku piekrišanas, pamatojoties uz pedagog̣iskās padomes ieteikumu, saskan,ojot šādu pārcelšanu ar pašvaldību un, ja, piemēram, nepieciešams valsts līmenī, ar Valsts Bērnu tiesību aizsardzības inspekciju (plašāk sk. Mihailovs, 2012).

Kā vēl vienu izeju disciplīnas problēmu risināšanai izglītỉbas iestādē, autora skatījumā, var izmantot jau šobrīd normatīvajā aktā noteikto iespēju slēgt ar izglītības iestādi līgumu par bērna izglïtošanu un aprūpi (ko pašreiz paredz Izglïīibas likuma 57. panta 3. punkts). Lai gan pašreiz šāda līguma slēgšana ir paredzēta kā vecāka tiesības bērna izglītošanas nodrošināšanai, tā būtu paplašināma. Pašlaik, pēc autora rīcībā esošās informācijas, šādu līgumu slēgšanu praktizē aptuveni 3\% vispārējās izglìtības iestāžu un dažas profesionālās izglitības iestādes, kuras šo praksi vērtē kā veiksmīgu.

Raksta autora skatījumā šajā līgumā, kuru var slēgt izglitības iestāde un vecāks / vecāki, bet, piemēram, no 11 gadiem (laiks, no kura var piemērot audzinoša rakstura piespiedu līdzekḷus) arī izglïtojamais (likums "Par audzinoša rakstura piespiedu lìdzekḷu piemērošanu bērniem"), varētu detalizēt pušu savstarpējās tiesības un pienākumus (jo normatīvie akti regulē tikai vispārējā rakstura jautājumus), savukārt nepieciešamības gadījumā šo līgumu varētu parakstīt arī pašvaldība, kurai saskaṇā ar likuma "Par 
pašvaldībām" 15. panta 4. punktā noteikto, ir autonomā funkcija "gādāt par iedzīvotāju izglìīibu" (iedzīvotājiem noteikto tiesību nodrošināšana pamatizglìtības un vispārējās vidējās izglìtības iegūšanā (likums "Par pašvaldībām")), kā arī noteikt pušu atbildību, dažādus atbalsta pasākumus un strīdu risināšanas mehānismus (piemēram, attīstot mediāciju izglìīibas iestādēs). Šāds līgums būtu nozīmīgs instruments, nosakot izglītības iestādes un vecāku savstarpējās sadarbības principus, ka arī veicinot gan paša izglìtojamā, gan viṇa vecāku atbildību, izglìtojamā tiesisko uzvedību un izglìtības iestādē noteiktās iekšèjās kārtības ievērošanu.

Vienlaikus raksta autors apzinās, ka minētais līgums nebūs universāls instruments visu disciplīnas problēmu risināšanai izglìīibas iestādē, drīzāk tam piemīt morāla (un arī juridiska) rakstura spēks (ietekme), uzlabojot pušu komunikāciju un samazinot gadījumus, kad pārkāpējs ne tikai izvairās no atbildības par izdarīto, bet dažreiz, dažādu iemeslu dẹl (kā norāda paši pedagogi - viṇu aizṇemtības un laika trūkuma, kā arī juridisko zināšanu nepietiekamības dẹḷ) viṇam pat netiek aizrādīts, kā arī pārkāpējs un viṇa vecāki neatzīst vai ignorē izglītîbas iestādes centienus noteikt problēmbērnam atbalsta pasākumus.

\section{Secinājumi}

Latvijas Republikā līdz šim ir noteiktas tikai vispārēja rakstura prasības izglītojamā uzvedībai un audzināšanai izglîtỉbas iestādē, atstājot izglîtỉbas iestāžu autonomai kompetencei vairāku būtisku audzināšanas, disciplīnas un uzvedības jautājumu risinājuma izvēli un attiecīgu noregulējumu.

Šobrīd spēkā esošie disciplīnas pārkāpumu novēršanas normatīvie akti un mehānismi ir nepilnīgi vai ir pietiekami komplicēti, piemērošanas procesā prasot gan juridiskās zināšanas un izglīīibas iestāžu vadības zināšanas, gan finanšu un cilvēkresursus, kuru trūkums vispārējās izglìtības un profesionālās izglìtības iestādēs ir acīmredzams. Arī izglītības iestāžu dibinātāji - pašvaldības - dažādu iemeslu dēḷ šobrīd nespēj pietiekami atbalstìt izglìtības iestādes, to vadītājus/kolektīvu.

To pietiekami spilgti apliecināja t. s. Jaunjelgavas gadỉjums. Viena izglìtojamā vardarbība parādīja izglìīibas iestādes, pašvaldības, tiesībsargājošo iestāžu darbinieku zināšanu trūkumu un nespēju risināt situāciju pēc būtîbas, kā arī faktiski noveda pie vainīgās personas un viṇas vecāku tiesību pārkāpumiem, tostarp vismaz dạ̣eji l̦aujot izvairīties no atbildības (piemēram, sk. Piekāst likumu, 2013).

Kopumā jaunpieṇemtais tiesiskais regulējums, nosakot izglītības iestādes direktora rīcību, ja izglìtojamais apdraud savu vai citu personu drošību, veselību vai dzīvību, šobrīd pilnībā nesasniedz savu mērḳi un ir pārskatāms, meklējot jaunus ceḷus (t. sk. pedagoǵiskos un tiesiskos) kā nodrošināt izglītojamo drošỉbu un novērst disciplīnas pārkāpumus izglītības iestādēs. Viens no šādiem risinājumiem ir nepieciešamība pilnveidot līguma par bērna izglìtošanu izglìtības iestādē regulējumu izglītību regulējošos normatīvajos aktos, kā arī popularizēt šì līguma piemērošanas praksi. 


\section{Contract for a Child's Education in Educational Establishment and Prevention of Breaches of Discipline in Latvia}

\section{Abstract}

One of the most serious social and educational problems in contemporary Latvia is the nihilistic behaviour of particular educates ignoring the established legal order and endangering the psycho-emotional welfare, health, safety, life of other persons. It is extremely hard to balance the interests of the majority (a class) and the minority (a problem child); especially in case a single child disturbs the study process for the entire class.

The aim of the topic is to analyse actual aspects of the prevention of breaches of discipline in general and vocational educational establishments and the possibilities to use a contract for a child's education as an upbringing tool.

Materials and methods used in the study include the analysis of regulations and its projects, Educational Management Practice.

In summer 2012, the Latvian society was debating about the proposal of the Ministry of Education and Science, which provides that, basing on the suggestion of the school board, the head of an educational establishment can impose a ban on aggressive children who endanger the health or safety of other persons - to prohibit them to attend the educational establishment for a definite time period (up to a month), i.e., to order in their families the acquisition of the educational content provided in the basic education programme. In case it is impossible to solve the problem situation within a month, the principal of the educational establishment can extend the ban up to two months.

This solution was not approved; therefore, in spring 2013 the proposal was elaborated and accepted, providing the possibility to isolate the aggressive educate with the implementation of special social-pedagogic support.

Such a solution can cause several essential problems: mostly human and finance resources and legal and pedagogical knowledge of the administration and support stuff of educational institutions, working separately with this aggressive educate.

Therefore, new regulation, protecting educates' safety, is quite human and optimal, but much more complicate is the implantation of this regulation in the educational establishments.

One possibility, which has so far been under-utilized to minimize breaches of discipline in general and vocational educational establishments, is a contract for a child's education in educational establishment.

Keywords: discipline, contract for a child's education in educational establishment, discipline breach prevention, educates, problem children. 


\section{Literatūra}

1. Aptauja: lielākā daḷa iedzìvotāju atbalsta ieceri agresīvos skolēnus apmācìt mājās, [skatīts 14.01.2015.]. Iegūts no: http://www.delfi.lv/news/national/politics/aptauja-lielaka-dala-iedzivotaju-atbalsta-ieceri-agresivos-skolenus-apmacit-majas.d?id=42601492

2. Izglìtība. DNB Latvijas barometrs, Nr. 61. [skatīts 14.01.2015.]. Iegūts no: https://www.dnb.lv/ sites/default/files/dnb_latvian_barometer/documents/2012/dnb-latvijas-barometrs-petijumsnr61.pdf

3. Grozījums Ministru kabineta 2009. gada 24. novembra noteikumos Nr. 1338 "Kärtība, kādā nodrošināma izglītojamo drošība izglìtības iestādēs un to organizētajos pasākumos” sākotnējās ietekmes novērtējuma ziṇojums (anotācija), [skatīts 14.01.2015.]. Iegūts no: mk.gov.lv/ doc/2005/IZMAnot_1207012_drosiba.764.docx

4. Izglìtības likums, [skatìts 14.01.2015.]. Iegūts no: http://likumi.lv/doc.php?id=50759

5. Likums "Par audzinoša rakstura piespiedu lïdzekḷ piemērošanu bērniem”, [skatīts 14.01.2015.]. Iegūts no: http://likumi.lv/doc.php?id=68489

6. Likums "Par pašvaldībām”, [skatīts 14.01.2015.]. http://likumi.lv/doc.php?id=57255

7. Metodiskie ieteikumi darbā ar skolēniem, kuriem ir agresìva uzvedība, [skatīts 14.01.2015.]. Iegūts no: http://izm.izm.gov.lv/upload_file/Ministrija/2012/Peetijums_agresiiva_uzv_2012.pdf

8. Mihailovs, I. J. Legal Culture of the Latvian Youth: Example of the Senior-Grade Elementary School Pupils. Vilnius: Mykolas Romeris University, 2012. 160 p.

9. Mihailovs, I. J. Skolēnu drošība un mācību disciplīnas pārkāpumu novēršanas aktuālie aspekti vispārējās izglītības iestādēs. 7. starptautiskā zinātniskā konference Teorija praksei mūsdienu izglìtībā. - Rīga: Rīgas Pedagog̣ijas un izglītības vadības akadēmija, 2014, 100.-105. lpp.

10. Mihailovs, I. J. Audzināšanas darbs vispārējās izglītības iestādēs Latvijā: organizēšanas un īstenošanas problēmas. Daugavpils Universitātes Sociālo zinātṇu fakultātes Starptautisko zinātnisko konferenču rakstu krājums. Starptautiskās zinātniskās konferences Sociālās zinātnes reǵionālajai attīstībai 2013 materiāli. I daḷa. Sociologijas aktualitātes. Daugavpils: Akadēmiskais apgāds "Saule", 2014, 37.-46. lpp.

11. Ministru kabineta 2009. gada 24. novembra noteikumi Nr. 1338 "Kärtība, kādā nodrošināma izglïtojamo drošìba izglìtības iestādès un to organizètajos pasākumos”, [skatìts 14.01.2015.]. Iegūts no: http://likumi.lv/doc.php?id=201106

12. Ministru kabineta noteikumu projekta "Grozijumi Ministru kabineta 2009. gada 24. novembra noteikumos Nr. 1338 "Kārtība, kādā nodrošināma izglìtojamo drošība izglìtības iestādēs un to organizētajos pasākumos"” sākotnējās ietekmes novērtējuma ziṇojums (anotācija), [skatīts 2015-14-01]. Iegūts no: www.mk.gov.lv/doc/2005/IZMAnot_190313_drosiba.591.doc

13. Piekāst likumu. Jurista Vārds, 2013, 4. jūn.

14. Špona, A., Čamane, I. Audzināšana. Pašaudzināšana. Teorija, pieredze, prakse. Rīga: RaKa, 2009. 260 lpp. 


\title{
Atjaunojamo energoresursu tiesiskuma nodrošinājums
}

\author{
Kristīne Šelepova \\ Rìgas Stradina universitāte, \\ Juridiskā fakultāte, Latvija
}

\section{Kopsavilkums}

Energoresursu pieejamība ir garantija valsts ekonomiskajai attīstībai un labklājībai. Latvijas elektroenergíjas tirgus pēdējā desmitgadē piedzìvo būtiskas pārmaiñas. Eiropas Savienības regulu un direktīvu harmonizācija nacionālajos normatīvajos aktos ir veicinājusi Latvijas elektroenerǵijas tirgus liberalizāciju, kā arī atjaunojamo energoresursu izmantošanas paplašināšanu Latvijā. Raksta mērḳis ir apzināt atjaunojamo energoresursu tiesisko regulējumu, tā atbalsta shēmas un problemātiku. Raksta autore skaidro, vai šo tiesību aizsardzības līmenis ir pietiekams, vai ir pieṇemtas nepieciešamās materiālo tiesību normas, kā arī vai ir pietiekoši tiesiskie lïdzekḷi, kas nodrošina šo tiesību aizsardzības ievērošanu, kā arī nākamos soḷus energoresursu liberalizācijas posmos. [1]

Atslēgvārdi: atjaunojamie energoresursi; energoresursu tirgus; elektroenergijas ražošana.

\section{levads}

Atbalsts atjaunojamo energoresursu izmantošanai pastāv visās Eiropas Savienības valstīs. Starp Baltijas valstīm atbalsts atjaunojamiem energoresursiem un efektīvai kog̣enerācijai, un bāzes jaudām vislielākais ir Lietuvā un Latvijā, bet vismazākais Igaunijā. AS "Latvenergo" kā publiskajam tirgotājam ir normatīvajos aktos uzlikts pienākums iepirkt elektroenerğiju no ražotājiem, kas elektroenergiju ražo, izmantojot atjaunojamos energoresursus, un kogenerācijā. Normatīvie akti nosaka arī kārtību, kādā publiskajam tirgotājam šã iepirkuma papildu izmaksas tiek kompensētas - visi elektroenerǵijas galalietotāji proporcionāli to elektroenerǵijas patērin̦am maksā obligātā iepirkuma komponenti, kuras aprēkinina metodiku nosaka regulators. Elektroenerğijas tirgus likumā ir nostiprināts mērḳis atjaunojamo energoresursu īpatsvara palielinājumam Latvijas elektroenergíijas patēriṇā. 
Pamatojoties uz nozares specifiku un to, ka darba tēmai nav plašas publikācijas, autore darba rakstǐšanā izmantoja gan Eiropas Savienības direktīvas, gan Latvijas Republikas likumus un Ministru kabineta noteikumus, kā arī praktisko darba pieredzi, kas gūta darba tiesiskajās attiecībās energétikas nozarē jau kopš 2007. gada.

\section{Atbalsta tiesiskais mehānisms elektroenerǵijas ražošanai no atjaunojamiem energoresursiem}

"Par atjaunojamajiem energoresursiem (AER) uzskata vēju, ūdeni, saules starojumu, biomasu (koksni, salmus, biogãzi, biodegvielu), zemes siltumu, viḷnus, kā arī paisuma bēguma procesus. Latvijā atjaunojamie energoresursi aizṇem vienu trešo daḷu primāro energoresursu bilancē, un divi visvairāk izmantotie atjaunojamo energoresursu veidi ir koksne un hidroresursi. Vēja enerǵija un biogāze tiek izmantota ievērojami mazākā apmērā. Saules enerǵiju šobrīd izmanto tikai l̦oti nelielos apjomos pilotprojektu formā. Atjaunojamie energoresursi var tikt izmantoti tieši vai arī pastarpināti, piemēram, no biomasas iegūstot transporta degvielas un cita veida šḳidro kurināmo". [2]

Atjaunojamajiem energoresursiem ir svarīga loma Eiropas Savienības politikā. Tã ir saistìta ar šo resursu izmantošanas pozitìvo ietekmi vairākos aspektos: iespējams ietaupīt fosilos energoresursus; samazināt izmešu daudzumu atmosfērā, augsnē un ūdenī; atjaunojamie energoresursi l̦auj dažādot energijijas ieguves veidus un avotus, izmantot vietējos resursus, tādējādi paaugstinot energoapgādes drošību un samazinot atkarību no enerǵijas importa; atjaunojamo energoresursu izmantošana l̦auj samazināt politiskos, vides un ekonomiskos riskus, kas pastāv uz fosiliem energoresursiem balstītā energoapgādes sistēmā; tā kā atjaunojamie energoresursi lielākoties ir vietējie resursi, tiek veicināta reǵionālā attīstība - radītas jaunas darbavietas, attīstās lauksaimniecība, mežsaimniecība, apstrādes rūpniecība un ar atjaunojamo energoresursu tehnologijām saistìtā pētniecība.

Latvijā par speciālajiem atjaunojamās enerǵijas jomu regulējošiem normatīvajiem aktiem ir uzskatāms 1998. gada 3. decembra Energèetikas likums, 2005. gada 5. maija Elektroenerǵijas tirgus likums un saskaņa ar to izdotie Ministru kabineta 2010. gada 16. marta noteikumi Nr. 262 "Noteikumi par elektroenerǵijas ražošanu, izmantojot atjaunojamos energoresursus, un cenu noteikšanas kārtību” un Ministru kabineta 2009. gada 10. marta noteikumi Nr. 221 "Noteikumi par elektroenergijas ražošanu un cenu noteikšanu, ražojot elektroenerğiju kogenerācijā", kā arī 2000. gada 19. oktobra likums "Par sabiedrisko pakalpojumu regulatoriem" un saskaṇā ar to izdotie Ministru kabineta noteikumi.

Saskan̄ā ar Eiropas Parlamenta un Padomes 2009. gada 23. aprīla Direktīvu 2009/28/EK "Par atjaunojamo energoresursu izmantošanas veicināšanu", ar ko groza un sekojoši atcel̦ Direktīvas 2001/77/EK un 2003/30/EK, Latvijai noteiktais vispārējais mērḳis ir palielināt no AER saražotās enerǵijas īpatsvaru kopējā enerǵijas bruto galapatēriñā līdz 40\% 2020. gadā. Direktīvas 25. pants nosaka: "Dalībvalstīm ir atškirīgs atjaunojamo energoresursu potenciāls, un tās izmanto dažādas atbalsta shēmas 
atjaunojamo energoresursu atbalstam valsts mērogā. Lielākā daḷa dalībvalstu piemēro atbalsta shēmas, ar kurām nodrošina priekšrocības vienīgi tai enerǵijai no atjaunojamajiem energoresursiem, ko ražo to teritorijā. Lai valsts atbalsta shēmas pareizi darbotos, ir būtiski, lai dalïbvalstis varētu kontrolèt savu valsts atbalsta shēmu ietekmi un izmaksas atbilstīgi savam atšḳirīgajam potenciālam. Svarīgs līdzeklis, kā panākt šajā direktīvā noteikto mērḳi, ir nodrošināt valsts atbalsta shēmu pareizu darbību atbilstīgi Direktīvai 2001/77/EK, lai tādējādi saglabātu ieguldītāju uzticību un dotu iespēju dalībvalstīm izstrādāt efektīvus valsts pasākumus mērḳu sasniegšanai”. [3]

Būtiskākie Direktīvas 2009/28/EK punkti nosaka: izveidot vienotu sistēmu no atjaunojamajiem energoresursiem saražotas enerǵijas izmantošanas veicināšanai; noteikt, ka no atjaunojamajiem energoresursiem saražotas enerǵijas īpatsvars 2020. gadā Latvijā ir vismaz 40\% no kopējā enerǵijas bruto galapatēriņa; noteikt, ka no atjaunojamajiem energoresursiem saražotas enerǵijas īpatsvars visā transportā 2020. gadā Latvijā ir vismaz 10\% no energiijas galapatēriņa transportā; izklāsta noteikumus par statistisko pārdali dalībvalstu starpā, par kopīgiem dalībvalstu un trešo valstu projektiem, izcelsmes apliecinājumiem, administratīvajām procedūrām, informāciju un mācībām, kā arī no atjaunojamajiem energoresursiem saražotās energíjas pievadi elektrotīkliem; tie arī nosaka ilgtspējīgus kritērijus biodegvielai un biologiskajiem šķidrajiem kurināmajiem.

Direktīva 2009/28/EK ir Eiropas Savienības enerǵêtikas politikas vēsturē pirmais mēginājums radìt visaptverošu tiesisko ietvaru atjaunojamo energoresursu izmantošanas veicināšanai galvenajos energêetikas sektoros: elektrības ražošanā, siltumapgādē, dzesēšanas un transporta sektoros. Lai veicinātu Direktīvas 2009/28/EK prasību izpildi 2010. gada 16. martā tika pieñemti Ministru kabineta noteikumi Nr. 262 "Noteikumi par elektroenergijas ražošanu, izmantojot atjaunojamos energoresursus, un cenu noteikšanas kārtïbu".

Latvija par atbalsta instrumentu ir izvēlējusies elektroenergíijas obligātā iepirkuma mehānismu, kas ir viens no garantēta iepirkuma paveidiem. Valsts pārvaldi atjaunojamo energoresursu jomā pārstāv Ekonomikas ministrija, kas ar Energétikas departamenta starpniecību īsteno energeetikas pārvaldes funkcijas, izstrādājot energétikas politikas, dokumentus un tiesỉbu aktu projektus, tostarp arī atjaunojamo energoresursu jomā, veicinot enerğijas lietotājiem piegādāto energoresursu efektīvu un ekonomisku izmantošanu, sekmējot investīciju piesaistīšanu energétikā, kā arī energoapgādes komersantu objektu modernizācijā un būvniecībā. Jaunu elektroenerǵijas jaudu ieviešanai, plānojot ražot elektroenergiiju no atjaunojamo energoresursiem, vispirms ir nepieciešama Ekonomikas ministrijas izdota aț̣auja elektroenergijas ražošanas jaudu palielināšanai vai jaunu jaudu ieviešanai. Gadījumos, ja plānotā elektriskā jauda pārsniedz 1 MW, komersantiem nepieciešams saṇemt arī Sabiedrisko pakalpojumu regulēšanas komisijas licenci elektroenergijas ražošanai.

Analizējot atjaunojamo energoresursu veidus pēc to potenciāla un iespējamā devuma nākotnē, lai izvērtētu primāri atbalstāmos atjaunojamo energoresursu veidus mērḳa izpildīšanā Latvijā, par galvenajiem izmantojamiem resursiem tiek novērtēta biomasa, galvenokārt koksne, kā arī vēja energíija, biogāze un hidroenergija. Šo resursu 
potenciāls nav vēl pilnībā izmantots. Tāpēc galvenais stratēgiskais mērḳis atjaunojamo energoresursu jomā ir optimāla Latvijas atjaunojamo energoresursu potenciāla izmantošana, ṇemot vērā ekonomiskās, geoogrāfiskās un tehniskās iespējas, kā arī pēc ekonomiskajiem, vides un enerğètikas attīstības aspektiem, vienlaikus ṇemot vērā starptautiskos un Eiropas Savienības politikas mērḳus un prasības attiecībā uz atjaunojamajiem energoresursiem. Eiropas Savienības normatīvo dokumentu harmonizācija nacionālajos tiesību aktos sniedz obligāti pildāmas prasības un sasniedzamos kvantitatīvos mērķus atjaunojamo energoresursu īpatsvara palielināšanā, siltumnīcefekta gāzu izmešu samazināšanā un energoefektivitātes paaugstināšanā.

Lai gan atjaunojamo energoresursu nozīme valsts ekonomikā ir l̦oti svarīga, sabiedrības attieksme nav vienāda, un bieži vien tā ir pat negatīva. Piemēram, SIA "Energy Investment" Cēsīs plānoja būvēt biogāzes kogenenerācijas kompleksu ar kopējo jaudu 2,4 megavati. Enerğiju bija paredzēts ražot no atjaunojamiem resursiem - kukurūzas, zāles, sausajiem kūtsmēsliem. Stacija ražotu gan siltumenerǵiju, gan elektroenerǵiju. Veicot šìs ieceres sabiedrisko aptauju, viedokli par kogenerācijas stacijas būvniecību izteica vairāk nekā 2000 cilvēku, un gandrīz visi bija pret šā objekta būvniecību Cēsu pilsētā, norādot, ka vēlas dzìvot tīrā vidē un elpot tīru gaisu, kā arī uzsverot Cēsu kā kultūras un tūrisma pilsētas nozīmi. Pamatojoties uz aptauju, Cēsu novada dome noraidīja SIA "Energy Investment" koǵenerācijas elektrostacijas būvniecības ieceri, par ko uzṇēmums vērsās ar pieteikumu Administratīvajā tiesā. Ar Administratīvās tiesas lēmumu tika ierosināta administratīvā lieta pēc SIA "Energy Investment" pieteikuma par pienākuma uzlikšanu Cēsu novada domei akceptēt biomasas kogenenerācijas būvniecības ieceres plānu un izsniegt plānošanas arhitektūras uzdevumu. SIA "Energy Investment" savā pieteikumā norādỉja, ka publiskās apspriešanas rezultātā iegūtais sabiedrības viedoklis nevar kalpot par pamatojumu būvniecības aizliegšanai un domes lēmumā nav norādīta neviena tiesību norma, uz kuras pamata dome būtu tiesīga aizliegt būvniecību. Patlaban gan Administratīvā tiesa nav pieņēmusi spriedumu šajā lietā, bet tas varētu kḷūt par tiesu prakses labu piemēru, ka sabiedrïbas viedoklis var ietekmēt atjaunojamo energoresursu ražošanas veidus.

\section{Obligātā iepirkuma atbalsta shēma, tā tiesiskās īpatnības}

Elektroenerğijas obligātais iepirkums ir valsts noteikts atbalsta mehānisms elektroenergíijas ražotājiem, paredzot tā finansēšanu no elektroenerǵijas galalietotāju maksājumiem. 2005. gada 5. maija Elektroenerğijas tirgus likuma 28. pantā un 29. pantā noteikts, ka ražotāji, kuri elektroenerğiju ražo efektīvā kog̀enerācijā vai elektroenergijas ražošanai izmanto atjaunojamos energoresursus, var iegūt tiesības pārdot saražoto elektroenergiiju obligātā iepirkuma ietvaros. 28. panta 2. dạ̣ā noteikts, ka: "Kritērijus, pēc kādiem koǵenerācijas elektrostacijas tiek kvalificētas šā panta pirmajā daḷā noteikto tiesību iegūšanai, obligātā iepirkuma un tā uzraudzības kārtību, elektroenerǵijas cenas 
noteikšanas kārtỉbu atkarībā no kogeneneāijas stacijas elektriskās jaudas un izmantojamā kurināmā, obligātā iepirkuma izmaksu segšanas kārtību un kārtību, kādā var atteikties no tiesībām pārdot saražoto elektroenergiju obligātā iepirkuma ietvaros, nosaka Ministru kabinets". [5] Tādi paši kritēriji tiek noteikti 29. panta 4. dạ̦ā attiecībā uz elektroenergiju, kas ražota, izmantojot atjaunojamos energoresursus: "Nosacījumus elektroenerǵijas ražošanai, izmantojot atjaunojamos energoresursus, kā arī kritērijus ražotāju kvalifikācijai šā panta pirmajā dạ̦ā noteikto tiesību saṇemšanai un kārtību, kādā var atteikties no tām, elektroenergijas cenas noteikšanas kārtību atkarībā no atjaunojamo energoresursu veida, obligātā iepirkuma apjoma noteikšanas, ìstenošanas un uzraudzības kārtību, obligātā iepirkuma apjoma izmaksu segšanas kārtību, kā arī pasākumus, lai veicinātu elektroenerǵijas ražošanu no biomasas, nosaka Ministru kabinets." [5]

Atbilstīgi 2005. gada 5. maija Elektroenerǵijas tirgus likuma 33. pantam AS "Latvenergo", kas pilda publiskā tirgotāja funkcijas, ir jāiepērk elektroenerǵija no koǵenerācijas stacijām un stacijām, kas izmanto atjaunojamos energoresursus, obligātā iepirkuma ietvaros. Ja minētiem elektroenerǵijas ražotājiem ir piešķirtas tiesības pārdot elektroenerğiju obligātā iepirkuma ietvaros, AS "Latvenergo" veic obligāto iepirkumu uz līguma pamata atbilstīgi minēto normatīvo aktu prasībām. Tiesības pārdot saražoto elektroenerǵiju obligātā iepirkuma ietvaros piešķir Ekonomikas ministrija. Nosacijjumus elektroenerǵijas ražošanai un cenu noteikšanas kārtību regulē Ministru kabineta noteikumi, t. i., 2010. gada 6. marta Ministru kabineta noteikumi Nr. 198 "Noteikumi par elektroenergiijas ražošanu, izmantojot atjaunojamos energoresursus, un cenu noteikšanas kārtību"; 2011. gada 29. novembra Ministru kabineta noteikumi Nr. 914 "Elektroenerğijas tirdzniecỉbas un lietošanas noteikumi".

AS "Latvenergo" katru gadu aprēkina un publicē precizētu no atjaunojamiem energoresursiem saražotās elektroenergijas apjomu turpmākajiem gadiem, n̦emot vērā iepriekšējā gada faktiskos rādìtājus.

Elektroenerǵijas obligātā iepirkumu cena ir daudzkārt augstāka nekā pieejamā elektroenergíijas cena tirgū. Rezultātā rodas papildu izmaksas, kas būtībā veidojas no obligātā iepirkuma un tirgus sektora cenu starpỉbas. Šìs papildu izmaksas veido obligātā iepirkuma komponentes, kuras apstiprina Sabiedrisko pakalpojumu regulēšanas komisija. Saistītajam lietotājam šīs izmaksas tiek apkopotas un piemērotas elektroenerǵijas tarifā, savukārt tirgus dalībniekiem - proporcionāli to elektroenergiijas patēriṇa apjomam - jāmaksā par katru komponenti.

Atbilstīgi 2009. gada 19. augusta Sabiedrisko pakalpojumu regulēšanas komisijas padomes lēmumā Nr. 1/2 apstiprinātajai obligātā iepirkuma komponenšu aprēkinināšanas metodikai, obligātā iepirkuma komponentes regulators apstiprina un publicē vienu reizi gadā, un tās attiecīgi stājas spēkā katru gadu 1. aprīlì. Obligātā iepirkuma komponentes izmaiṇas ir saistītas ar publiskā tirgotāja AS "Latvenergo" izmaksu izmaiṇām elektroenerǵijas iepirkšanai no atbalstāmajiem elektroenerǵijas ražotājiem. Normatīvie akti paredz - lai veicinātu elektroenerǵijas ražošanas attīstību Latvijā, 
noteiktiem ražotājiem (kas ražo elektroenerğiju efektīvā kogenenēcijā vai no atjaunojamiem energoresursiem - tās ir biomasas un biogāzes ražotnes, mazās hidroelektrostacijas un vēja stacijas) ir tiesības pārdot elektroenerǵiju par atbalsta cenu, kas ir augstāka nekā elektroenerǵijas tirgus cena. Elektroenerğiju no minētajiem ražotājiem par atbalsta cenu iepērk AS "Latvenergo" - šis pienākums ir noteikts Sabiedrisko pakalpojumu regulěšanas komisijas izsniegtajā elektroenerğijas tirdzniecības licencē. Lai kompensētu AS "Latvenergo" izdevumus, kas uzṇēmumam radušies, iepērkot obligāti iepērkamo elektroenerğiju, regulators apstiprina obligātā iepirkuma komponentes, kuras maksā visi Latvijas elektroenergijas galalietotāji proporcionāli to elektroenergijias patērina apjomam. Atbilstīgi 2011. gada 29. novembra Ministru kabineta noteikumu Nr. 914 41. pantam: "Lietotājs - elektroenerğijas tirgus dalībnieks - proporcionāli elektroenerğijas patēriṇam maksā par katru obligātā iepirkuma komponenti. Par obligātā iepirkuma komponenti maksā attiecīgajam elektroenerǵijas pārvades vai sadales sistēmas operatoram kopā ar maksu par pārvades vai sadales sistēmas pakalpojumiem." [7] Savukārt saistītajam lietotājam šīs izmaksas tiek apkopotas un piemērotas elektroenergijas tarifā.

Apstiprinātās komponentes kompensē publiskajam tirgotājam obligātā iepirkuma radìtos papildu izdevumus, salīdzinot ar tāda paša apjoma elektroenerğijas iepirkumu elektroenerğijas tirgū. Kā jau minēts iepriekš, atbalsta elektroenerğijas cena ražotājiem tiek noteikta, lai radītu viņiem ekonomiski pamatotu interesi darboties Latvijas teritorijā un nodrošinātu, lai valsts teritorijā tiktu saražota pēc iespējas lielāka daḷa no elektroenergíijas patērētājiem nepieciešamā elektroenerǵijas apjoma.

Arī citās Eiropas Savienības valstīs elektroenerğijas izmaksās lietotājiem tiek iekḷautas obligātā iepirkuma komponentes, bet katrā valstī obligātā iepirkuma atbalsts un tā iekḷaušana elektroenerǵijas tarifā tiek veidota atšḳirīgi un arī n̦emot vērā katras valsts specifiku elektroenerǵijas ražošanā, piemēram, Igaunijā šì komponente ir mazāka nekā Latvijā, jo Igaunijā elektroenergiija, kas saražota izmantojot atjaunojamos energoresursus un kogeneneācijā, ir krietni mazākā apjomā nekā Latvijā. Daḷā Eiropas Savienības valstu šīs komponentes tiek pieskaitìtas pie pārvades vai sadales tarifa.

2010. gada 16. martā tika izdoti Ministru kabineta noteikumi Nr. 262 "Noteikumi par elektroenerǵijas ražošanu, izmantojot atjaunojamos energoresursus, un cenu noteikšanas kārtību", kas ietver nosacījumus elektroenerǵijas ražošanai, izmantojot atjaunojamos energoresursus, kā arī kritērijus ražotāju kvalifikācijai tiesību iegūšanai pārdot no atjaunojamo energoresursu saražoto elektroenergiju obligātā iepirkuma ietvaros. Atbilstīgi noteikumiem obligātā iepirkuma tiesību pieškirš̌ana biomasas, biogāzes, saules un vēja elektrostacijām notika konkursa kārtībā. Komersants varēja iegūt arī tiesības saṇemt garantēto maksu par elektrostacijā uzstādìto elektrisko jaudu. Piešķirtais atbalsta termiṇš no ekspluatācijas uzsākšanas brīža ir noteikts 10 gadu periodam, un pèc šā laika turpmākos 10 gadus tiek piemērots samazināts atbalsta apmērs. No 2011. gada 26. maija ministrija konkursus par tiesību iegūšanu pārdot elektrostacijās saražoto elektroenerǵiju obligātā iepirkuma ietvaros neorganizē, 
un ražotājs nevar kvalificēties elektroenerğijas pārdošanai obligātā iepirkuma ietvaros un tiesību iegūšanai saṇemt garantētu maksu par uzstādīto elektrisko jaudu.

Ministru kabineta 2009. gada 10. marta noteikumi Nr. 221 "Noteikumi par elektroenerğijas ražošanu un cenu noteikšanu, ražojot elektroenerǵiju koǵenerācijā" savukārt regulē kogenerācijas procesā saražotas elektroenerğijas obligāto iepirkumu par noteiktu cenu, kā arī tiesības uz garantētas maksas par koǵenerācijas elektrostacijā uzstādīto elektrisko jaudu saṇemšanu. Esošās vai plānotās kogenerācijas stacijas, kas izmanto atjaunojamos energoresursus, atbalstam varēja pieteikties lìdz 2012. gada 9. septembrim. Vienlaikus, uzlabojot atbalsta mehānismu, ar Ministru kabineta 2012. gada 28. augusta noteikumiem Nr. 604 "Grozijumi Ministru kabineta 2009. gada 10. marta noteikumos Nr. 221 "Noteikumi par elektroenerǵijas ražošanu un cenu noteikšanu, ražojot elektroenerǵiju koǵenerācijā"” noteikts atbalsta terminna ierobežojums - 10 gadi (koǵenerācijas elektrostacijām, kuru uzstādītā elektriskā jauda nepārsniedz $4 \mathrm{MW}$ ) un 15 gadi (kogenerācijas elektrostacijām, kuru uzstādītā elektriskā jauda ir lielāka par $4 \mathrm{MW}$ ) garantētai maksai.

Pēdējā laikā lielu publicitāti ir saṇēmis obligātā iepirkuma komponentes pieaugums 2013. gada 1. aprīlī. Salīdzinājumam - 2012. gadā tika apstiprināta summārā obligātā iepirkuma komponente par kogenerācijā un no atjaunojamiem energoresursiem saražotās elektroenerǵijas iepirkumu - 12,30 Ls/MWh, bet 2013. gadā 18,90 Ls/MWh, kas vidēji veido 35\% pieaugumu.

Šāds pieaugums ir saistîts ar palielinātajām cenām: iepirkuma cenu no vēja stacijām, hidroelektrostacijām, biomasu un biogāzi izmantojošām elektrostacijām, tāpat obligātās iepirkuma komponentes palielinājums ir saistìts ar gāzes cenu svārstībām, kas tieši ietekmē iepērkamās elektroenerǵijas cenu. Kopumā tas rada ne tikai risku samazināt elektroenerǵijas lietotāju maksātspēju, kā arī uzṇēmumu konkurētspēju, radot draudus valsts tautsaimniecíbai. Tādēḷ 2012. gadā turpmāka tiesību pieškiriršana pārdot elektroenerǵiju obligātā iepirkuma ietvaros vai saṇemt garantētu maksu par elektrostacijā uzstādìto jaudu, lai sakārtotu un uzlabotu esošo atbalsta sistēmu kopumā, ir apturēta. Lìdz 2016. gada 1. janvārim jauni komersanti nevar kvalificēties tiesību iegūšanai pārdot saražoto elektroenerğiju obligātā iepirkuma ietvaros un tiesību iegūšanai saṇemt garantētu maksu par elektrostacijā uzstādīto elektrisko jaudu.

2013. gada 27. martā Sabiedrisko pakalpojumu regulēšanas komisija ir izstrādājusi un publicējusi priekšlikumus obligātā iepirkuma komponenšu reālai samazināšanai. "Regulatora priekšlikumi attiecas gan uz visu veidu elektroenerǵijas ražotājiem, gan uz iespējamām izmaiṇām nodokḷu politikā: pārskatìt atbalstāmajiem ražotājiem noteiktās cenu veidošanas formulas, un tās veidot no diviem saskaitāmajiem - cenas mainīgās daļas, kas atkarīga no mainīgajām izmaksām, un cenas pastāvīgās dạ̦as, kas atkarīga no elektrostacijas veida un jaudas; atcelt piesaisti dabas gāzes cenām, tā var tikt saglabāta tikai tām elektrostacijām, kas izmanto dabas gāzi; stimulēt ražošanas efektivitāti un atbalstu attiecināt tikai uz investīciju atgūšanas periodu - cenas pastāvīgās daḷas saskaitāmā koeficienti jāizvēlas tā, lai pie optimālas jaudas izmantošanas, investīcijas 
būtu atgūstamas noteiktā laikā ar saprātīgu atdeves likmi; paredzēt atbalsta intensitātes samazināšanu, ja elektrostacijas projekts ir sanēemis vai saṇems investīciju atbalstu citu atbalsta programmu ietvaros, piemēram, no ES fondiem; noteikt būtisku atbalsta intensitātes samazinājumu koǵenerācijas elektrostacijām, kuru uzstādītā elektriskā jauda ir lielāka par $4 \mathrm{MW}$, modificējot formulas gan energijas, gan jaudas komponentei tā, lai samazinātu saṇemto atbalsta apjomu, jaudas komponentes noteikšanā izmantojot ražošanas alternatīvas etalonu - efektīvas gāzes kombinētā cikla kondensācijas elektrostacijas pastāvīgajām izmaksām, komponentes lielumu nosakot atkarībā no uzstādītās jaudas - jo lielāka jauda, jo mazāka jaudas komponente, kā arī jaudas komponentes noteikšanas formulā iestrādājot mehānismu, kas stimulē elektrostacijas īpašnieku pārdot elektroenerǵiju tirgū, lai atgūtu ne tikai mainīgās, bet arī pastāvīgās izmaksas, un tādējādi nepieḷaujot, ka pie labvēlīgiem tirgus apstākḷiem pastāvīgās izmaksas tiktu atgūtas lielākā apmērā nekā nepieciešams; veikt izmaiņas nodokḷu politikā, akcīzes nodokli dabasgāzei nenosakot lielākā apmērā, kā to paredz ES, un tādējādi samazināt gan nodokḷa likmi, gan apliekamo bāzi." [9]

\section{Secinājumi}

Atjaunojamo energoresursu izmantošana palielina neatkarību no importētiem energoresursiem, samazina siltumnīcefekta gāzu emisijas apjomu, kā arī palielina energijas apgādes drošību. Tomēr energèetiḳi atzīst, ka energosistēmas kḷūst ievainojamākas, jo vēsturiskās, patstāvīgās bāzes jaudas tiek aizvietotas ar ražošanu no atjaunojamiem energoresursiem. Tas saistìts ar subsīdijām, jo investīciju prioritāte ir rentablākie atjaunojamo resursu projekti. Tādējādi ir jāpievēršas risinājuma izstrādei, kā nepastāvīgos un neprognozējamos atjaunojamos energoresursus integrēt Eiropas elektroenerğijas tirgū, vienlaikus nodrošinot drošu un nepārtrauktu elektroapgādi.

\section{Legal Regulation of Renewable Energy}

\section{Abstract}

Use of renewable energy increases independence from imported energy, reduces greenhouse gas emissions, as well as increases security of energy supply. However, energy industry concedes that power becomes more vulnerable because of historical paradigms; independent power base is replaced with production from renewable energy sources. This is due to subsidies in the investment priority being cost-effective renewable resources projects. Thus, it is necessary to develop a solution defining how volatile and unpredictable renewable energy sources integrated into the European electricity market can be, while ensuring safe and uninterrupted power supply.

Keywords: renewable energy, energy markets, power generation. 


\section{Literatūra}

1. Šel̦epova, K. Elektroenerǵijas tirgus liberalizācijas tiesiskais regulējums. Bakalaura darbs. Rīga: RSU, 2013.

2. Energétika Latvijā. Politikas apskats - beta versija. Iegūts no: http://energetika-lv.wikidot.com/aer

3. 2009. gada 23. aprīla Eiropas Parlamenta un Padomes Direktìva 2009/28/EK par atjaunojamo energoresursu izmantošanas veicināšanu un ar ko groza un sekojoši atcel Direktìvas 2001/77/ EK un 2003/30/EK. Iegūts no: http://old.eur-lex.europa.eu/LexUriServ/LexUriServ.do?uri=OJ :L:2009:140:0016:0062:LV:PDF

4. Ministru kabineta 2010. gada 16. marta noteikumi Nr. 262 "Noteikumi par elektroenerǵijas ražošanu, izmantojot atjaunojamos energoresursus, un cenu noteikšanas kārtību”. Iegūts no: http://www.likumi.lv/doc.php?id=207458

5. Elektroenergijas tirgus likums. Latvijas Republikas likums pieṇemts 2005. g. 5. maijā, ar grozījumiem, kas pienemti lïdz 2012. g. 1. janv. Iegūts no: http://www.likumi.lv/doc.php?id=108834

6. 2009. gada 19. augusta Sabiedrisko pakalpojumu regulēšanas komisijas padomes lēmums Nr. 1/2 "Obligātā iepirkuma komponenšu aprēḳināšanas metodika”. Iegūts no: http:// www.likumi.lv/doc.php?id=196347

7. Ministru kabineta 2011. gada 29. novemra noteikumi Nr. 914 "Elektroenerǵijas tirdzniecības un lietošanas noteikumi”. Ar grozījumiem, kas pieņemti līdz 2012. g. 31. aug. Iegūts no: http:// www.likumi.lv/doc.php?id=241279

8. Ministru kabineta 2010. gada 16. marta noteikumi Nr. 262 "Noteikumi par elektroenerǵijas ražošanu, izmantojot atjaunojamos energoresursus, un cenu noteikšanas kārtību”. Ar grozījumiem, kas pieñemti līdz 2012. g. 8. sept. Iegūts no: http://www.likumi.lv/doc.php?id=207458

9. 2013. gada 27. marts. Sabiedrisko pakalpojumu regulēšanas komisija. Informācija plašsaziṇas līdzekḷiem. Iegūts no: http://www.sprk.gov.lv/?id=16487\&sadala=237 


\title{
Bērna tiesības zināt savu izcelsmi: tiesību apjoms un aktuālie problēmjautājumi
}

\author{
Olga Škserberga \\ Rīgas Dome, Rīgas bārintitiesa", Latvija
}

\section{Kopsavilkums}

Informācija par izcelsmi ir būtiska personas identitātes sastāvdaḷa, tā ir viena no bērna pamattiesībām un ietilpst tiesības uz privātās dzīves aizsardzību tvērumā. Bērna tiesības zināt savu izcelsmi, tāpat kā tiesības uzaugt gímenē vai tiesības tikt uzklausītam, ir viena no pamattiesībām, ko aizsargā starptautiskie akti. Tomēr šīs tiesības îstenošana nacionālajā līmenī pilnībā liegta bērniem, kuri ir adoptēti, dzimuši izmantojot donora dzimumšūnas, un glābējsilītē ievietotiem bērniem.

Atslēgvārdi: izcelsme, adopcija, glābējsilīte, medicīniskā apauglošana.

\section{Raksta mērḳis}

Raksta mērḳis ir atklāt tiesiskā regulējuma problēmas bērna tiesībām zināt savu izcelsmi adopcijas, glābējsilī̌u un medicīniskās apaug̣̦ošanas gadījumā, izvirzot priekšlikumus risinājumiem taisnīga līdzsvara nodrošināšanai indivīdu konkurējošu interešu aizsardzībā.

\section{Pētniecības metodes}

Izmantota vēsturiskā, deskriptīvā, analītiskā un salīdzinošā pētniecības metode. Analìtiskā metode izmantota, lai izpētìtu Latvijas un arì citu valstu nacionālos tiesību aktus, starptautiskos un reg̣ionālos tiesību avotus. Deskriptīvā (aprakstošā) metode

\footnotetext{
"Raksta autore nepauž Rīgas domes Rīgas bāriṇtiesas viedokli. Raksta pamatā ir autores maǵistra darbs "Bērna tiesības zināt savu izcelsmi: apjoms un aktuālie problēmjautājumi", kas 2014. gada 31. janvārī aizstāvēts RSU Juridiskās fakultātes maǵistra darba novērtēšanas komisijā. Mağistra darbs pilnā apjomā ar nosaukumu "Bērna tiesības zināt savu izcelsmi. Aktuālie problēmjautājumi” 2014. gada 29. septembrī izdots akadēmiskajā izdevniecībā "Globe Edit”.
} 
izmantota, lai aprakstītu jēdzienu skaidrojumus. Vēsturiskā metode tiek lietota, lai uzsvērtu, kā starptautiskā un regionālā līmenī ir attīstījušās bērnu tiesības zināt savu izcelsmi, vecākus. Salīdzinošā metode tiek izmantota, lai parādītu, kā bērna tiesības zināt vecākus tiek īstenotas citās valstīs, lai salīdzinātu un izvērtētu dažādu valstu tiesību zinātnieku atziņas, kā arī lai aizgūtu idejas nepilnību novēršanai nacionālajos tiesību aktos, ja konstatēta neatbilstība starp uzn,emtajām saistībām un bērna tiesībām zināt savu izcelsmi regulējumu Latvijas tiesību aktos.

\section{Diskusija un rezultāti}

Sabiedriskajā telpā izskanēja informācija, ka ANO Bērnu tiesību komitejas pārstāve vēlas aizliegt glābējsilïtes, jo to pastāvēšana pārkāpj bērnu tiesības zināt, kas ir viṇu vecāki, un veidot ar viṇiem personiskas attiecības. [16] Šì ziṇa autorei raisīja pārdomas par to, vai un kādā apjomā valsts atzīst un aizsargā ANO Konvencijā un ECT Konvencijā garantētās bērna pamattiesības zināt savu izcelsmi nacionālā tiesību sistēmā arī medicīniskās apauglošanas gadỉjumā, kad piekḷuve informācijai par bērna izcelsmi ir liegta donora anonimitātes aizsardzības dẹl, un adopcijas gadïjumā, kad ziņas par bērna izcelsmi liedz izpaust adopcijas noslēpums.

Bērna tiesības zināt savus vecākus ir viena no ANO 1989. gada 20. novembra Konvencijas par bērna tiesībām (turpmāk - ANO Konvencija) 7. panta pirmajā daḷā noteiktajām bērna pamattiesībām. Šìs tiesības tostarp izriet no 1950. gada 4. novembra Eiropas Cilvēktiesību un pamatbrīvību aizsardzības konvencijas (turpmāk - ECT Konvencijas) 8. panta pirmajā dạ̣ā ietvertā jēdziena "privātā dzīve" interpretēšanas. [4,5] Bērna tiesības zināt savu izcelsmi nav absolūtas. ANO Konvencijas 7. panta pirmajā daḷā ietvertā klauzula "ciktāl tas iespējams" ierobežo šo tiesību piemērošanu bez nosacījumiem, tā attiecināma uz šādiem gadījumiem:

1) ja vecāku nav iespējams identificèt;

2) ja māte atsakās izpaust bērna tēva identitāti, iekḷaujot situācijas, ja bērns ieñemts incesta vai izvarošanas rezultātā;

3) ja valsts ir izlēmusi, ka vecāki nedrīkst tikt identificēti. [13, 117]

Tomēr trešo gadījumu kategorija ietver visstrīdīgākos aspektus bērnu tiesību ierobežošanas nepieciešamībā un pamatotībā, jo klauzulas interpretācijas rezultātā dažkārt nevajadzīgi tiek pārkāptas bērna tiesības zināt savus vecākus. No Eiropas Cilvēktiesību tiesas (turpmāk - ECT) prakses atziṇām izriet, ka tiesību uz privātās un giimenes dzīves neaizskaramību ierobežojums ir attaisnojams, lai aizsargātu citu personu tiesības un brīvības, ja vien ierobežojums ir samērīgs ar sasniedzamo mērḳi. [6, 7]

Nemot vērā, ka bērna tiesības zināt savu izcelsmi izriet no starptautiskā un reǵionālā līguma, tad aplūkojot ANO un Eiropas Padomes (turpmāk - EP) nostāju, secināms, ka ANO pauž nepārprotamu nostāju nepieciešamībā nodrošināt bērnam tiesības zināt savus vecākus, iesakot novērst anonīmi atstāto bērnu praksi, kā arī nodrošināt adoptētiem un medicīniskās apaugḷošanas ceḷā dzimušiem bērniem tiesības zināt savus 
izcelsmes vecākus. [10, 11] EP savukārt atzīst, ka visiem bērniem ir likumīgas intereses attiecībā uz vinu izcelsmi, piel̦aujot, ka dalībvalstis nacionālajos tiesību aktos drīkst ierobežot vai liegt bērnam piekḷuvi informācijai par savu izcelsmi, ja šis ierobežojums atbilst bērna vai iesaistīto personu interesēm. [12] Līdz ar to šo tiesību ierobežojums vai liegums attaisnojams, izvērtējot bērna vai iesaistìto personu intereses. Absolūts bērna tiesību liegums zināt savu izcelsmi ir pretrunā starptautiskajām prasībām.

Tiesību zinātnieces Katerina Donovana un Jaijna Kothari norāda, ka bērnam ir nepieciešams darīt zināmu informāciju par savu izcelsmi psiholoğiskas nepieciešamības dẹl, vēlmes zināt savu un senču slimību vēsturi un mantojuma tiesiskās intereses dēḷ. İpaši tiek uzvērta psiholoǵiskā nepieciešamība, jo šìs informācijas trūkums bērnam var izraisìt personības attīstības problēmas. [14, 15] Jānorāda, ka tiesību zinātnieku vidū nav vienprātības par donoru identificējošas informācijas izpaušanu bērnam. Džeina Stolle, piemēram, norāda, ka, neatkarīgi no bērna izcelšanās veida, dalībvalstij ir pienākums nodrošināt, lai bērna tiesības zināt savus vecākus tiktu aizsargātas, savukārt Irina Dikova uzskata, ka dzimumšūnu donora anonimitātes aizliegšanas gadijumā strauji samazināsies dzimumšūnu donoru skaits. [17, 18]

Vērtējot nacionālo tiesību aktu atbilstību starptautiskajām prasībām, atzīstams, ka tiesību normās ir pārṇemti vadošie ANO Konvencijas tiesību principi, to skaitā tiesības būt informētam par savu izcelsmi, tomēr dažu tiesību normu interpretēšanas rezultātā tiesību normu piemērotājs var nonākt pie nepamatota bērna tiesības uz izcelsmi aizskāruma. Proti, Bērnu tiesību aizsardzības likuma (turpmāk - BTAL) 8. pants noteic, ka bērnam ir tiesības uz individualitāti, kas sevī ietver tiesības. uz savas identitātes saglabāšanu. Jēdziens identitāte likumā nav definēts, tomēr, atsaucoties uz judikatūrā izteiktām atzin̄ām, norādāms, ka "bērnu vislabākās intereses un identitātes izjūtu var saglabāt, neliedzot vinịiem iegūt zināšanas par savu izcelsmi. Ar identitātes saglabāšanu apzīmē gan neiejaukšanos identitātē, gan arī ierakstu, kas saistīti ar genealoǵiju, dzimšanas reǵistrāciju un detalizētu informāciju par bērnības agrīno posmu, ko bērns nevar atcerēties, saglabāšanu." [1]

Citā spriedumā tiesa norāda, ka "identitāte nozīmē vairāk nekā tikai zināšanas, kas ir viṇa vecāki. Brāḷi un māsas, vecvecāki un citi radinieki var būt tikpat vai vēl vairāk svarīgi bērna identitātes apzināšanai nekā tikai vecāki" un ka "koncepcija par bērna identitāti ir koncentrējusies uz bērna tuvāko gimeni”. [2] No minētā tiesas skaidrojuma izriet, ka jēdziens identitāte aptver vairākus aspektus, ar to saprotot gan neiejaukšanos identitātē, gan ierakstu saglabāšanu saistībā ar genealoǵiju un dzimšanas regiistrāciju, kā arī neliegšanu iegūt zināšanas par savu tuvāko ǵimeni, piemēram, adoptētājiem, bet no minētā neizriet, ka bērns var iegūt informāciju par savu bioloǵisko ğimeni, jo tā nav viṇa tuvākā goimene.

Bērnam, kurš atrodas ārpusğimenes aprūpē, ir tiesības būt informētam par to, kas ir viṇa vecāki, to nosaka BTAL 34. pants. Likumā nav dots skaidrojums jēdzienam vecāks, tomēr, ņemot vērā, ka bērna un vecāka personiskās tiesiskās attiecības regulē Civillikums (turpmāk - CL), un atsaucoties uz tiesas sniegtu skaidrojumu, norādāms, 
Olga Šḳerberga. Bērna tiesības zināt savu izcelsmi: tiesību apjoms un aktuālie problēmjautājumi

ka "CL izpratnē par vecākiem atzīstamas, nevis tādas personas, no kurām bērns ir cēlies, bet kurām ir likumā noteiktā kārtībā nodibināts attiecīgs statuss vai šis statuss likumā noteiktā kārtībā nav atṇemts." [3] Attiecīgi secināms, ka bērnam ir tiesības būt informētam par saviem juridiskajiem vecākiem, bet ne izcelsmes vecākiem, ja tie zaudējuši vecāka statusu. No sniegtās interpretācijas izriet, ka subjektu loks, kam šì norma ir piemērojama, kḷūst vēl mazāks, jo faktiski tikai likumā īpaši paredzētos gadījumos, bērnam atrodoties ārpusğimenes aprūpē, viṇa vecākiem netiek pārtrauktas aizgādības tiesības.

Latvijas nacionālo tiesību normas aizsargā adoptētāja tiesības uz anonimitāti un aizliedz izpaust ziṇas par adopcijas faktu jebkurām personām, to skaitā adoptētajam līdz pilngadības sasniegšanai, līdz ar to Civilstāvokḷa aktu likuma 9. panta otrajā dạ̣ā un CL 171. panta trešajā daḷā ir ievērotas EP Konvencijas par bērnu adopciju 20. panta trešajā punktā noteiktās prasības. Tomēr, vērtējot nacionālo tiesību normu atbilstību ANO Konvencijas 7. panta pirmās daḷas prasībām kopsakarā ar ANO pausto nostāju, jānorāda, ka bērnam, kurš ir adoptēts, nav nodrošinātas tiesības zināt savu izcelsmi. Šāds aizliegums adoptētajam zināt savu izcelsmi nav objektīivi pamatots un samērīgs ar sasniedzamo mērki. Autore par piemērotāko risinājumu interešu līdzsvarošanai uzskata Francijas tiesiskā regulējuma modeli.

Lielākajā dạ̦ā ANO un EP dalībvalstu, tostarp arī Latvijā, donoru anonimitāte tiek vērtēta augstāk nekā bērna tiesības zināt savu genētisko vēsturi, jo ziṇas par biologiskajiem vecākiem var ietekmēt gan neauglīgos vecākus un bērnu integrēšanos ğimenē, gan donorus. [8] Jānorāda, ka nepastāv vienots pareizs anonimitātes risinājums, jo vienlaikus saduras trīs atškirīgas intereses - domājamo vecāku un donora tiesības uz privātumu un anonimitāti un bērna tiesības zināt izcelsmi. Ne vienmēr ir iespējams vienlaikus nodrošināt šo tiesību ievērošanu, tomēr, lai īstenotu ANO un ECT Konvencijā noteiktās prasības, iespējamais risinājums būtu paredzēt kompetentai institūcijai izvērtēt, kādā apjomā šĩ informācija ir izpaužama, n̦emot vērā bērna vecumu un briedumu, nepārkāpjot dzimumšūnu donora un juridisko vecāku tiesības uz privātumu. Šāda informācija ietvertu genealoǵiska rakstura datus, ziṇas par dzimumšūnu donora tautību, slimību vēsturi u. c., bez personas identificējošu datu atklāšanas.

Glābējsilī̌su projekts sabiedriskajā telpā ir aktualizējis jautājumu par bērna izcelsmi un genealogiiska rakstura informācijas pieejamības nodrošināšanu bērnam. Glābējsilìtē atstātajam bērnam nav iespējams īstenot tiesības zināt savu izcelsmi, jo bērna vecāki nav zināmi. Tomēr, ja bērna māte izvēlēsies dzemdēt bērnu, neizpaužot savu identitāti vai uzdosies par citu personu, arī tad šo tiesību nodrošināšana nebūs iespējama, jo valsts iestāžu rīcībā nebūs ziṇu par bērna izcelsmi. No otras puses, liedzot iespēju bērna mātei palikt anonīmai, paredzot atbildību par bērna atstāšanu, bet savukārt tādā veidā nodrošinot bērnam noteiktās tiesības zināt izcelsmi, iespējams, var panākt pretēju rezultātu - abortu skaita pieaugumu, zīdaiṇu mirstības skaita palielināšanos. Vērtējot glābējsilīšu darbību no apskatītā aspekta, secināms, ka bērna tiesības zināt savu izcelsmi pretnostatītas bērna tiesībām uz dzīvību. Tiesības 
uz dzīvību ir pirmatnējas, fundamentālas pamattiesības, ar kurām ir apveltīta ikviena cilvēciska būtne, un bez kuru aizsardzības visas pārējās cilvēktiesības kḷūst mazāk nozīmīgas jeb mazāk efektīvas.[9, 63] Bērna dzīvība ir galvenā pamatvērtība, tāpēc šìs tiesības aizsardzība prevalē pār bērna tiesību zināt savu izcelsmi. Atsaucoties uz klauzulai sniegto skaidrojumu, norādāms, ka glābējsilīšu gadījumā netiek nevajadzīgi pārkāptas bērna tiesības zināt savu izcelsmi, jo iestāžu rīcībā nav ziṇu par bērna izcelsmes vecākiem.

\section{Secinājumi}

Izvērtējot ANO un EP nostāju, veicot ECT un Latvijas tiesu prakses analīzi, autore secina, ka, lai nodrošinātu nepārprotamu bērna tiesību zināt savu izcelsmi izpildi nacionālā līmenī, nepieciešams iekḷaut BTAL 8. pantā trešo daḷu un izteikt to šādā redakcijā: (3) "Bērnam ir tiesības zināt savu izcelsmi likumā noteiktā kārtībā."

Šāda papildinājuma iekḷaušana l̦aus izvairīties no jēdziena "identitāte" nepamatoti sašaurinātas interpretācijas, piemērojot tiesību normas. Papildus nepieciešams veikt grozijjumus speciālajos likumos par adopcijas un medicinniskās apaug̣̦ošanas tiesisko regulējumu, tādējādi panākot taisnīgu līdzsvaru pretēju interešu aizsardzībā. Saskaṇā ar starptautiskajām saistībām, kuras Latvija uzṇēmusies, ir jābūt noteiktam tiesiskam regulējumam, kas ḷauj bērnam realizēt ANO un ECT Konvencijās garantētās tiesības zināt savus izcelsmes vecākus, ja valsts rīcībā tādas ziṇas ir.

\section{Rights of a Child to Know its Origin: Volume and Topical Issues of Concern}

\section{Abstract}

The objective of the article is to analyse problems of legal frameworks of a child's rights to know its origin in case of adoption, baby boxes and medically assisted fecundation, as well as to put forth amendments in the legislation if discrepancy is ascertained between international commitments of a state and regulation in the national legislation of a child's rights to know its origin. Implementation of a child's right to know its origin is analysed, examining the attitude of subjects of international public law - the United Nations and the Council of Europe in supervision of children's legal interests; performing research of regulatory enactments, recommendations and directions, judgements of courts and comparing legal framework of a child's rights to know its origin in the Republic of Latvia.

Keywords: origin, adoption, baby boxes, medically assisted fecundation. 


\section{Literatūra}

1. Administratīvās rajona tiesas 2013. gada 5. aprīla spriedums lietā Nr. A420586212 (A02582-12/21), 10. rindkopa.

2. Administratīvās rajona tiesas 2013. gada 25. aprīla spriedums lietā Nr. A420554312 (A02353-13/36), 12. rindkopa.

3. Administratìvās apgabaltiesas 2013. gada 27. augusta spriedums lietā Nr. A420560012 (AA43-2733-13/10), 4., 6. rindkopa.

4. Eiropas Cilvēktiesību tiesas 1989. gada 7. jūlija spriedums Gaskin vs. The United Kingdom (Nr. 10454/83), \$ 39.

5. Eiropas Cilvēktiesību tiesas 2002. gada 7. februāra spriedums lietā Mikulić vs. Croatia (Nr. 53176/99), $\$ 53$.

6. Eiropas Cilvēktiesību tiesas 2002. gada 5. novembra spriedums lietā Yousef vs. the Netherlands (Nr. 33711/96), \& 59.

7. Eiropas Cilvēktiesību tiesas 2003. gada 13. februāra spriedums lietā Odièvre vs. France (Nr. 42326/98), $\mathbb{} 33$.

8. Mileiko, I. Biodrošîbas aspektu izvērtējums mākslīgās apaugḷošanas gadījumā. Priekšizpētes ziṇojums, Rīga, 2010, [skatīts 28.10.2013.]. Iegūts no: http://www.biodrosiba.lu.lv/fileadmin/ user_upload/lu_portal/projekti/biodrosiba/IMileiko_Maksliga_apauglosana.pdf

9. Bertrand, G. R. The right to life in International Law. Netherland: Martinus Nijhoff Publishers, 1985, p. 63.

10. Concluding Observations of the Committee on the Rights of the Child, France, U.N. Doc. CRC/C/15/Add.240, 2004, p. 23, 24, [skatīts 18.08.2013.]. Iegūts no: http://korczak.fr/partenaires/ong/cdre_recomm_040604.pdf

11. Concluding Observations of the Committee on the Rights of the Child. United Kingdom of Great Britain and Northern Ireland, U.N. Doc. CRC/C/15/Add.188, 2002, 31, 32 p., [skatits 18.08.2013.]. Iegūts no: http://www2.ohchr.org/english/bodies/crc/docs/AdvanceVersions/ CRC.C.GBR.CO.4.pdf

12. Council of Europe. Draft Recommendation on the rights and legal status of children and parental responsibilities. Strasbourg, 8 April 2011, CJ-FA-GT3, 2010, art. 4 (2).

13. Implementation handbook for the Convention on the rights of the child. Rachel Hodgkin and Peter Newell, Unicef, 2002, p. 117.

14. O’ Donovan, K. A. Right to know ones parentage? International Journal of Law, Policy and the Family, Vol. 2, 1988, p. 28.

15. Kothari, J. The child's right to identity: Do adopted children have the right to know their parentage?, [skatìts 10.08.2013.]. Iegūts no: http://www.cry.org/resources/pdf/NCRRF/NCRRF_ ReportBy_Jayna.pdf

16. Randeep, R. Spreadof 'baby boxes' in Europe alarms United Nations. The Guardian, 10.06.2012., [skatīts 18.08.2013.]. Iegūts no: http://www.theguardian.com/world/2012/jun/10/ unitednations-europe-news? INTCMP=SRCH

17. Stoll, J. Surrogacy Arrangements and Legal Parenthood. Swedish Lawin a Comparative Context. Uppsala: Uppsala Universitet, 2013, p. 39.

18. Аикова, И. А. Актуальнье проблемь донорства половых клеток. Право и жизнь, № 136, 2009, [skatīts 03.11.2013.]. Iegūts no: http://www.law-n-life.ru/arch/n136.aspx 


\title{
Psiho- un neirotehnoloǵijas un sabiedriskās drošības problēmas
}

\author{
Andrejs Vilks \\ Rīgas Stradiña universitāte, Juridiskā fakultāte, Latvija
}

\section{Kopsavilkums}

Raksta autors publikācijā vēlas pievērst lasītāju uzmanību vienai no iespējamām jaunajām pieejām tiesībaizsardzības iestāžu darbībā - psiho- un neirotehnologijām -, kā arī autors pakavēsies pie minētās tēmas jaunākajām iezīmēm. Rakstā ir ieskicēti psihotehnoloğiskās izziņas un ietekmēšanas daži aspekti, neirotiesībzinātnes (neirolaw) attīstības kontūras, kā arī psihotehnologijas studiju kursu realizēšanas prakse un iespējas juristu profesionālajā izglītībā, nepretendējot uz tēmas plašu un dziḷu izklāstu.

Psiho- un neirotehnologiju izmantošana tiesību aizsardzības iestāžu darbībā ir pietiekami jauna. Vismaz Latvijas tiesiskajā, kā arī medicīniskajā pētniecības un praktiskajā darbībā. Tomēr speciālie dienesti atbilstīgas tehnoloǵijas visai sekmīgi ir izmantojuši jau divdesmitā gadsimta sākumā. Kaut gan psihotehnologiiju izmantošanas vēsture ir krietni senāka. Pašreiz paredzamas daudz plašākas psihotehnolog̣iju izmantošanas iespējas tiesību aizsardzības iestāžu darbībā.

Atslēgvārdi: sabiedriskā drošỉba, psihotehnolog̣ijas, neirotehnolog̣ijas, tiesībaizsardzības iestādes, noziedzība.

\section{levads}

Problēmas aktualitāte izpaužas nepieciešamībā apzināt minēto tēmu un tās izpētes iespējas, kas saistītas ar vairākām apstākḷu grupām.

Pirmkārt, ar jaunu noziedzīgo nodarījumu veidu, kā arī paṇēmienu izmantošanu, veicot kriminālās aktivitātes. Visai plaši ir pieejami dažādu metodiku apraksti ar personu psihiskās ietekmēšanas paṇēmieniem, ir izveidoti kursi indivīdu psihiskajā ietekmēšanā - psihotehniskie pañēmieni tiek izmantoti veicot krāpšanas, īpašuma zādzības, ḷaunprātīgi izmantojot dienesta stāvokli. Psihotehnologijas tiek prasmīgi un aktīvi izmantotas, lietojot modernos tehniskos komunikācijas līdzekḷus (e-pastu, Skype, mobilos sakarus), veicot praktiski anonīmu saskarsmi u. c. 
Otrkārt, lai gan jaunās tehnologijas ir plaši pieejamas, tiesību aizsardzības iestāžu darbībā tās tiek izmantotas nepietiekami un nepilnīgi. Daudzos gadījumos tiesībaizsardzības struktūrās trūkst informācijas par šādām tehnolog̣ijām, to izmantošanas iespējām un rezultativitāti noziedzīgo nodarījumu novēršanā un apkarošanā, identificējot nodarījumus izdarījušās personas, vācot lietiskos pierādījumus, kā arī veicot noziedznieku psihokorekciju.

Treškārt, daži medicīniskie un starpdisciplinārie pētījumi un zinātnisko izstrāžu rezultāti, to skaitā neirologiijā, varētu sniegt pilnīgi jaunas iespējas personu izziṇā un vinu pretsabiedriskās un noziedzīgās uzvedības korekcijā.

Ceturtkārt, psihotehnologijas ir iespējams izmantot, pilnveidojot tiesību aizsardzības iestāžu vienotību, iekšējo mobilitāti, profesionalitāti, novēršot psihotraumatismu, "izdegšanu” un deformāciju.

Arī Latvijā psihotehnologiiju izmantošanā ir zināma pieredze. 2008. gadā Latvijas Policijas akadēmijas, Kriminālistikas katedrā tās vadītāja Dr. habil. iur. profesora A. Kavaliera vadībā tika sākta projekta izstrāde par noziegumu atklāšanu un nozīmīgas informācijas ieguvi, izmantojot hipnozi. Projekta sākuma posmā tika apzināta hipnozes izmantošana ārvalstu tiesiskajā praksē, hipnozes stāvoklī iegūtās informācijas izmantošana izmeklēšanas darbībās. [9]

Darba pamatmērḳis ir apzināt pašreizējo, galvenokārt ārvalstu tiesību aizsardzības iestāžu praksi, psiho- un neirotehnologiiju izmantošanas pieredzi.

Psihotehnologiju izmantošana noziedzīgo nodarījumu atklāšanā un novēršanā ir perspektīva, jo balstās uz tiesisko un medicīnisko pieeju, dod iespējas izstrādāt interdisciplināru lietošanas metodiku, kā arī sniedz atbalstu, pilnveidojot tiesiskās politikas vadlīnijas, uzlabojot tiesību aizsardzības iestāžu organizatorisko potenciālu. Pētījuma gaitā izstrādātie materiāli zināmā mērā jau tiek izmantoti jauno speciālistu - ārstu, juristu, psihologu, psihoterapeitu, sociālo darbinieku u. c. - izglìtošanā. Izstrādes rezultāti varētu attīstīt psihotehnoloǵiju izmantošanu noziedzīgo nodarījumu atklāšanā un novēršanā, apzināt psihotehnologiiju lietošanu no medicīniskā aspekta, izstrādāt to lietošanas metodiku, kā arī pilnveidot sociālo politiku, uzlabojot tiesībaizsardzỉbas iestāžu organizatorisko potenciālu.

\section{Noziedzīgos nodarījumus veic nevis cilvēki, bet viņu smadzenes}

Dažu valstu tiesiskajā praksē aizvien biežāk tiek izmantoti neirobiologiskie pētỉjumi, kas ḷauj liecināt ne tikai par indivīdu vainu izdarītajos noziedzīgajos nodarījumos, bet arī var atspēkot viṇu vainīgumu un minimizēt iespējas nevainīgas personas sodīšanai. Uz tiesas sēdēm par ekspertiem tiek uzaicināti neirologi, kuri izsaka viedokli par apsūdzēto psihisko stāvokli noziedzīgā nodarījuma izdarīšanas brīdī. Pēc Djuka universitātes profesores Naitas Farahani (Nita Farahany) domām (viņa vienlaikus ir arī ASV prezidenta Baraka Obamas padomniece bioētikas jautājumos), pašreiz ASV tiesās, 
kur tiek skatītas lietas par slepkavībām, neirologi tiek uzaicināti apmēram 5\% gadījumu no skatāmajām lietām. [7] Advokāti, izmantojot neirolog̣iskos izmeklējumus, cenšas pierādìt, ka viṇu klientu nežēlība, vardarbība un impulsivitāte ir izskaidrojama ar neirologiska rakstura novirzēm, kas izslēdz apsūdzēto vainīgumu. Ja 2005. gadā ASV pēc neirobiologu palīdzības advokāti vērsās 30 slepkavību lietās, tad 2012. gadā minētais radītājs jau sasniedza 100 gadījumus. Neirobioloǵiskie izmeklējumi biežāki ir noziegumos, kurus veic nepilngadīgie, jo viṇu psihofizioloğiskās iespējas kontrolēt savu uzvedību vēl neesot pilnīgi attīstìtas.

Advokāti arī izmanto neirobioloǵisko pētījumu rezultātus, kuri liecina par pusaudžu augsto ietekmējamību, runājot par paṇēmieniem, kas tiek izmantoti policijas izmeklēšanas procesā, iegūstot aizdomās turēto personu atzišanās liecības. Kopumā, advokāti tiesas izmeklēšanas procesā plaši izmanto argumentu, ka izdarītajos sevišḳi smagajos noziegumos noteicošais faktors ir apsūdzēto nekontrolējamās smadzenes un vinu psihiskie procesi.

\section{Cilvēku psihotehnoloǵiskā izziṇa un ietekmēšana}

Cilvēku psihotehnolog̣iskās ietekmes veidi ir diezgan dažādi. Psihotehnologiskā ietekme var būt diferencēta atkarībā no saskarsmes veida - tieša vai netieša; no izmantotajiem psihotehnologiskajiem līdzekḷiem - tehnologiska (tehnogēna), vizuāla, verbāla, mentāli energètiska; atkarībā no ietekmes objektu aptvēruma - individuālā, grupu, masveidīga; atkarībā no ietekmēšanas mērḳa - pozitīva, sociāli neitrāla, negatīva u. c.

Psihotehnologiskās ietekmēšanas rezultātā tiek veidota (programmēta) darbība, kuru indivīds nespēj kontrolēt. Ārstniecībā šādai ietekmei var būt pozitīva nozīme (novēršot indivīda depresīvo vai paaugstinātas agresivitātes stāvokli, ietekmējot atkarību pārtraukšanu utt.). Tomēr aizvien biežāk psihotehnologiskā (psihoenergétiskā) ietekme tiek izmantota pretēji cilvēku saprātīgajām interesēm (izstrādājumu, preču, pakalpojumu, kreditēšanas, reklāmas kampaṇu ekspansijai).

\section{Neirotehnoloǵijas tiesību aizsardzības vidē}

Neirotehnologiijas pēdējā desmitgadē attīstās sevišḳi strauji, kas ir saistīts ar jaunu cilvēka izpētes metožu izmantošanu, to skaitā - funkcionālās magnētiskās rezonanses tomogrāfijas, magnētiskās encilogrāfijas, elektroencilogrāfijas, infrasarkanās spektroskopijas, datortomogrāfijas un pozitronu emisijas tomogrāfijas lietošanu. RSU Psihosomatiskās medicīnas un psihoterapijas katedras pasniedzējs Artūrs Utināns atzīst, ka jaunās neirozinātnes var tikt izmantotas cilvēku individuālās uzvedības prognozēěanā, nosakot ieslodzīto paaugstinātas agresivitātes un antisociālas personības iezìmes. [10] Ar atbilstīgu tehnolog̣iju palīdzību būtu iespējams identificēt teroristus vai pat pedofilus. Izmantojot cilvēka domu rekonstruēšanu elektroniskajās sistēmas (Visual Image Reconstruction from Human Brain), ir iespējams lasìt cilvēka domas datorā. Neirovizualizācijas tehnologija ir izveidojusi pat jaunu nozari - neirojurisprudenci (neirolaw). 
Tiesiskajā un medicīniskajā praksē aizvien biežāk tiek lietota tā saucamā "smadzeñu pirkstu nospiedumu metode" (brain fingerprinting). Metodika dod iespējas atjaunot un vizualizēt atmiņu fragmentus, kuri ir saistìti ar cilvēka iepriekšējo darbību vai apstākḷiem, kādos viṇš ir atradies. Magnētiskā stimulācija sekmē smadzeṇu segmentu aktivizāciju. Veicot pārrunas ar indivīdu (aptauju, nopratināšanu), tiek noteikta viṇa reakcija uz noteiktiem vārdiem, frāzēm, attēliem, lietām. "Smadzeṇu pirkstu nospiedumu" tehnoloǵijas autors ir Lorens Faruels (Lawrence Farwell). Minētā metodika, kuras nosaukums ir Mermer, tika izmantota par pierādījumu ASV Aijovas štatā Terrija Haringtona lietā. [8] Sākotnēji vinsš tika apsūdzēts slepkavībā. Vēlāk, izmantojot "smadzeņu pirkstu nospiedumu" metodi, tika konstatēts, ka apsūdzētajam ir alibi, bet liecinieks, kurš sniedza liecību par T. Haringtonu, melo. "Smadzennu pirkstu nospiedumu" metode tika izmantota, pierādot sērijveida slepkavas Džeimsa B. Grindera vainu trīs sieviešu nogalināšanā. [4]

"Smadzeņu pirkstu nospiedumu" metodikas pamatā ir cilvēka smadzeṇu impulsīva reakcija zemapziņas līmenī uz ārējo stimulu 300 milisekundēs; piemēram, parādot indivīdam pazīstama cilvēka fotoattēlu, atbilstīgais smadzenuu segments to atpazīst. Smadzeṇu psihiskās reakcijas nav iespējams ietekmēt un kontrolēt. Testēšanas procesā nav nepieciešama indivīda verbāla atbilde. Uz pārbaudāmās personas galvas tiek izvietoti elektroniskie sensori, kas fiksē reakcijas un novada tās uz datoru. Stimuls, uz kuru reaǵē pārbaudāmā persona, var būt skaṇas, vārdi, attēli, smaržas, lietas, datorattēls (zīmes, simboli). Stimulu pazī̌sanas noliegums tikai pierāda testējamās personas negodigumu.

Neirojurisprudence ir jauna multidisciplināra zinātne, kura ietver tiesību zinātni un neirolog̣iju. Tās izziņas joma ir neirolog̣ijas atklājumu izmantošana jurisprudencē, pētot, analizējot un vērtējot tiesiska rakstura parādības, faktus un tiesību subjektu uzvedības modeḷus. Starptautiskajā terminologijā tiek lietoti tādi termini kā Legal Neuroscience, Law and Neuroscience, Neurolaw, Neurojurisprudence, kā arī Neurocriminology. Neirojurisprudencē tiek apzinātas iespējas un robežas, cik lielā mērā neirologijas secinājumi ir izmantojami tieslietās.

Neirojurisprudence un tās inovatīvās pieejas galvenokārt tiek lietotas kriminolog̣ijā, kriminālistikā un kriminālprocesā.

Kriminologiijas ietvaros apzinot individuālā noziedzīgā nodarījuma mehānismu, neirolog̣ijas līmenī ir iespējams izpētìt ārējās sociālās (mikro) vides apstākḷu iespaidu uz indivīda psihiskajiem procesiem, stāvokli un īpašībām. Kriminologijā būtiski ir izzināt neiroloğijas atzīmes par indivīda pretsabiedrisko orientāciju, noviržu un motīvu veidošanos. Ne mazāk nozīmīgi ir jautājumi par individuālās tiesiskās apzinnas un kultūras veidošanās procesu, tā deformāciju. Arvien vairāk neirologijas sasniegumi varētu būt izmantojami personu, kuras ir izdarījušas noziedzīgos nodarỉjumus, resocializācijā probācijas dienestā. Neirologijas metodikas varētu būt izmantojamas jaunpieṇemto tiesisko aktu akceptēšanā individuālā līmenī. 
Individuālo kriminālo aktu cēloṇus agrāk meklēja galvaskausa uzbūves anomālijās, cilvēka konstitucionālās uzbūves īpatnībās, hromosomu patalogiijās, genētiskās novirzēs. Neirolog̣iskā pieeja ir saistīta ar noziedzịgas uzvedības cēloṇu apzināšanu cilvēka smadzenēs, neironos.

Neirolog̣ijā ir izpētīta serotonīna ietekme uz cilvēka agresīvu vai depresīvu uzvedību. Serotonīns tiek raksturots kā mīlestības un laimes hormons, kas nosaka indivìda laimes sajūtu un indivīda labsajūtu, un emocionālo komfortu. Izpētes rezultāti liecināja, ka serotonīna līmeņa samazināšanās veicināja indivīdu paaugstinātu agresivitāti vai depresiju, kas varēja izmainīt suicīda izpausmes. Kā vardarbības pret apkārtējo vidi, kā arī autovardarbības (suicīdiem vai to mēǵinājumiem) ir vienots determinants serotonīna nepietiekamība cilvēka organismā.

Personām, kuras ir izdarījušas smagus noziegumus (slepkavības, smagus miesas bojājumus, izvarošanas u. c.), neirologiskā izpētē ir fiksēts pazemināts serotonīna lìmenis, lìdz ar to šādas personas, balstoties uz biologiskiem rādìtāiem, nespēj veikt tîšas, mērḳtiecīgas darbības. Pēc būtības viṇi pilnā mērā kontrolē savu uzvedību. Vinus varētu uzskatīt par dậeji pieskaitāmiem, un tiem var būt piemērots mazāks sods nekā personām, kurām serotonīns ir normālā līmenī.

Balstoties uz minēto pieeju, būtu vēlams apzināt, vai indivīdiem, kuri nodarījuši smagus noziegumus, ir iespējama medicinniskā izpēte, konstatējot viṇu serotonīna līmeni vai kontrolējot pazeminātu minētās vielas līmeni, vai ir iespējams noteikt viṇa pieskaitāmības pakāpi un spējas kontrolēt savu uzvedību. Kā apsekojums personām ar pazeminātu serotonīna līmeni ietekmēs soda noteikšanu?

ASV 2004. gadā tika sagatavots apkopojums par neirozinātnisko ietekmi un liecībām krimināltiesībās (An Overview of the Impact of Neiroscience Evidence in Criminal Law.). Apkopojums sastāv no šādām sadaḷām:

1) minētās atbildības nozīme krimināltiesībās;

2) procedūrjautājumiem par liecību sniegšanu kriminālprocesā;

3) neiroskenēšana un krimināltiesiskā prakse. [1]

Apkopojumā tiek atzīts, ka ASV tiesas aizvien biežāk tiesas izmeklēšanas gaitā izmanto smadzeņu skenēšanas dokumentus par zinātnisku pamatojumu procesa dalībnieku vainīgumam vai nevainīgumam. Tã lietā "ASV pret Erskinu" (United States vs. Erskine; 588 F, 2d, 721, 9th Cir., 1978) [5] Erskins tika apsūdzēts nepatiesu liecību sniegšanā teritoriālajai apdrošināšanas bankai. Apelācijas sūdzỉbu Erskins balstīja uz to, ka pirmās instances tiesa neaț̣āva atbildētājam pievienot liecībām viṇa smadzeṇu skenēšanas rezultātus, kuri liecināja par apsūdzētā nepietiekamajām mentālajām spējām, kas ietekmētu banku tās nepiemērotu lēmumu pieṇemšanā.

ASV apelācijas tiesa aț̣āva vēlāk pievienot Erskina smadzeṇu skenēšanas rezultātus, un tiesa tika pārskatìta.

Apkopojuma autori atzīst, ka būtu vēlams procesos iesaistītajām pusēm nepieciešamības gadỉjumos pieprasīt smadzeṇu skenēšanu personām, kuras tiek apcietinātas vai kā drošîbas līdzeklis tiek izvērtēts mājas arests, pārbaudot viṇu agresivitātes 
līmeni un bīstamību apkārtējiem iedzīvotājiem. Smadzeṇu skenējuma rezultāti ir nozīmīgi arī nosakot apsūdzēto vainas pakāpi un atbildības veidu.

Smadzeņu skenēšana tiek izmantota ne tikai ASV. 2013. gada jūnijā Indijā tiesa atzina par vainīgu kādu sievieti sava bijušā līgavaiṇa slepkavībā. Viṇai tika piespriests mūža ieslodzījums. Nekādi citi pierādỉjumi, kuri liecinātu par sievietes vainu, lietā fiksēti netika, izṇemot neirotehnologiskos sievietes smadzeṇu pètījumus. Pētỉjumā tika izmantota elektrisko smadzeṇu viḷnu izmaiṇu līknes analīzes metodika BEOS (Brain Electrical Oscillations Signature). Atbilstīgu pētijumu veica Indijas neirologs Čampadi Ramanoms Mukundanoms. [11]

BEOS metodika, balstoties uz encefalogrammas datiem, l̦auj noteikt, vai cilvēkam veidojas asociācijas un vai viņš domā par atsevišşu notikumu faktiem, kuri viṇam tiek atgādināti (stāstīti, rādīti). Zināmi fakti, darbība vai bezdarbība - tos atpazīstot, smadzenēs "izgaismojas" atsevišḳi segmenti, persona no jauna atceras izjusto un pārdzīvoto. Metodika tajā pašā laikā sniedz iespējas atškirirt, ko indivīds ir redzējis un ko darīiis. Tiek atzīts, ka minētā metodika arī palīdz noteikt, ko cilvēks plāno, tostarp viṇa pretsabiedriskās un kriminālās ieceres.

ASV prezidents Baraks Obama 2013. gada 2. aprīlī paziņoja, ka tiek uzsākta jauna zinātniskā programma "Cilvēka smadzeṇu izpēte, izmantojot inovatīvās neirotehnologijas" - BRAIN Initiative (Brain Research through Advancing Innovative Neurotechnologies). [2] Programmas mērḳis ir iegūt pilnu cilvēka smadzeṇu karti, kurā tiktu ietverti visi neironi un sinapses (neironu savienojumi). Programmas realizācijas terminš̌ - desmit gadi. Tās finansējums ir paredzēts kopš 2014. gada, pieškirot pirmatnējai tās izstrādei 100 miljonus ASV dolāru. 2013. gada nogalē bija jābūt gatavam programmas realizācijas plānam. Primārie programmas uzdevumi ir indivīdu dažādu slimību novēršana un ārstēšana (Parkinsona, epilepsijas un citu). Kā viens no iespējamiem projekta pasākumiem tika minēta palīdzības sniegšana posttraumatiskajiem militāro operāciju veterāniem, personām ar psihiskām saslimšanām. Perspektīvā tiek atzìts, ka datora programma atbilstīgu pētỉjumu rezultātā varēs reageèt uz cilvēku domām un izpausmes formām, valodas barjeras zudīs. Šajā pašā laikā sabiedrībā izskan pamatotas bažas, ka cilvēku domas, izjūtas un darbību varēs kontrolēt un korigèèt.

Arī Eiropas Savienības zinātniski pētnieciskās institūcijas ir vienojušās par cilvēka galvas smadzeṇu izpēti, realizējot projektu Human Brain Project. [6] 2013. gada oktobra sākumā Šveicē Eiropas 135 zinātniski pētniecisko iestāžu pārstāvji vienojās par desmitgadīga (2014-2023) projekta izstrādi. Projekta kopējās izmaksas 1,2 miljardi eiro.

Vēl 2012. gadā Lielbritānijas Karaliskā biedrība savā ziṇojumā pavēstīja, ka jaunākie pētījumi neirologiijas jomā tiks izmantoti brun,oto spēku un speciālo dienestu vajadzībām. [3] Neirolog̣iskās tehnologiijas tiek izmantotas jauniesaucamo karavīru testēšanā, lemjot jautājumu par viṇu nosūtī̌sanu dienestam atbilstīgākās bruṇoto spēku vienībās, dienesta gaitas novērošanā, kā arī pēctraumas rehabilitācijas procesā. Speciālisti atzīst, ka aizvien nozīmīgāki kḷūst jautājumi par tiesisko aktu pilnveidošanu, kas pilnīgāk spētu aizsargāt militārpersonas un civiliedzīvotājus no nelabvēlīgas psihotehnologiskās ietekmes. 


\section{Secinājumi}

Pašreizējās iespējas veikt no cilvēka gribas neatkarīgu viṇa izziṇu un iespējamās manipulācijas pieaug daudz straujāk nekā mēs to spējam apzināties. Jaunās tehnologiskās iespējas veicina cilvēka apdraudējumus. Tas nebūt nenozīmē, ka no jaunajām iespējām vispār būtu jāatsakās. Jauno tehnologiiju izmantošanā ir nepieciešams noteikt striktus tiesiskos pamatus un zinātniski objektīvu metodiku. Tehnologiju lietošanas mērḳiem un kārtībai ir jābūt morāli un ētiski sabiedrībā atbalstāmiem.

\section{Psycho and Neuro-technology and Public Safety Problems}

\section{Abstract}

The current capacity for the human beyond the control of his statement and possible manipulation is growing much faster than we are able to realize. New technological capabilities contribute to human threats. This does not mean that new capabilities are to be resigned form. Use of new technologies is necessary to identify legal basis and strict scientific methodology conversion lens. Technology use goals and policies have to be morally and ethically community assisted.

Keywords: public safety, psycho-technology, neuro-technology, law establishment, crime.

\section{Literatūra}

1. An Overview of the Impact of Neiroscience Evidence in Criminal Law. Iegūts no: http://bioethics.georgetown.edu/pcbe/background/neuroscience_evidence.html

2. BRAIN Initiative. Iegūts no: http://www.whitehouse.gov/share/brain-initiative

3. Brain Wawes Module 3. Conflict and Sesurity. Iegūts no: https://royalsociety.org/policy/ projects/brain-wawes/conflict-security

4. Farwell Brain Fingerprinting Catches a Serial Killer. Iegūts no: http://www.lawrencefarwell. com/Fairfield-Ledger-serial-killer-dr-larry-farwell-brain-fingerprinting-dr-lawrence-farwell. html

5. Glimcher, P. W. The neurobiology of individual decision making, dualism, and legal accountability in Engel, C., and Singer, W. (eds.), 2008. Better Than Conscious? Implacations for Performance and Institutiona Analysis, Strüngmann Forum Report 1, Cambridge, MA, MIT p. 341 Press. Iegūts no: http://www.decisionsrus.com/documents/the-neurobiology-of-individual-decision-making-dualism-and-legal-accountability.pdf

6. Human Brain Project. Iegūts no: https://www.humanbrainproject.eu/ 
7. Jean-Laurent, Cassely. C'est pas moi, c'est mon cerveau: les avocats américains abusent des neurosciences. Iegūts no: http://www.slate.fr/life/79941/avocats-defense-neurosciences.

8. Larry Farwell - Inventor of Brain Fingerprinting. Iegūts no: http://www.larryfarwell.com/ brain-fingerprinting-executive-summary-dr-larry-farwell-dr-lawrence-farwell.html

9. Miḳelsons, U. Kriminālistiskā hipnoze. Juridiskie un metodiskie aspekti. Rīga, 2008. Iegūts no: http://www.eksperts.gold.lv/Kriminalistiska_hipnoze.pdf

10. Kavalieris, A. Hipnozes izmantošana policijas aptaujā. Rīga: Latvijas Policijas akadēmija, 2009.

11. Utināns, A. Neirozinātnes policijas darbā. Iegūts no: http://www.rsu.lv/images/stories/dokumenti/zinu_pielikumi/Programma_un_tezes_13092013_RED_GALA.pdf

12. Нейротехнологии отправили человека за решетку. Iegūts no: http://www.mobiledevice.ru/ brain-electrical-oscillations-signature-beos-champadi-raman-muku.aspx 


\section{Autoru rādītājs}

Baumanis, Jānis 5

Girgensone, Barba 12

Kudeikina, Inga 19

Kuznecova, Kristīne 25

Matvejevs, Aleksandrs 35

Meija, Jānis 42

Mihailovs, Ivans Jānis 47

Šel̦epova, Kristīne 55

Šķerberga, Olga 64

Vilks, Andrejs 70 